\title{
CHECKS WITHOUT BALANCE: EXECUTIVE OFFICE OVERSIGHT OF THE ENVIRONMENTAL PROTECTION AGENCY
}

\author{
Robert V. Percival*
}

\section{INTRODUCTION}

The rise of the modern administrative state has been fueled by the explosive growth of federal regulatory legislation. By shifting policymaking authority from Congress to administrative agencies, regulatory legislation has helped to transform "the system of shared powers created by the Constitution" into "a system of shared influence over bureaucratic decisionmaking." 1 Nowhere is this transformation more apparent than in the competition between Congress and the president for control of federal environmental policy. This competition has stimulated the development of a new tool for executive influence on regulatory decisions: review of agency action by the Executive Office of the President. ${ }^{2}$ Presidential use of regulatory review and the congressional responses it has provoked pose new challenges to theories of the impact of separation of powers on federal policymaking.

This article explores the tension between the rule of law and the politics of regulation reflected in Executive Office oversight of the Environmental Protection Agency ("EPA"). Part II describes the history of the White House review programs, which were established out of concern over the impact of environmental regulation. Part III explores the broad impact of Executive Office oversight on EPA's rulemaking and decisionmaking processes. Part IV considers how Congress has responded to regulatory review by intensifying its own oversight activities and adopting increasingly prescriptive

Copyright (C) 1991 by Law and Contemporary Problems.

* Assistant Professor and Director of the Environmental Law Program, University of Maryland School of Law. The author served as lead counsel for plaintiffs in Environmental Defense Fund $v$ Thomas, 627 F Supp 566 (D DC 1986), which is discussed in a portion of this article.

The author would like to thank Douglas Costle, John Daniel, Arthur G. Fraas, Thomas $O$ McGarity, James Miller, III, Paul Portney, Edward A. Tomlinson, and David Vladeck for their comments and John Kalas for research assistance.

1. Peter L. Strauss, Legislative Theory and the Rule of Lau: Some Comments on Rubin, 89 Colum L Rev 427, 428 (1989), quoting Matthew D. McCubbins \& Terry O. Sullivan, eds, Congress: Structure and Policy 403 (Cambridge U Press, 1987).

2. This article refers to the various programs for exercising Executive Office oversight over agencies through systematic review of regulatory proposals as "regulatory review" programs. 
environmental legislation. Part $\mathrm{V}$ then evaluates the rationales offered to justify regulatory review and the limits of law as a constraint on the exercise of Executive Office oversight.

Finally, Part VI proposes a more balanced model of executive oversight that focuses on improving the process of regulatory decisionmaking rather than altering the substance of regulatory outcomes-a model more consistent with the president's constitutional duty to "take Care that the Laws be faithfully executed."'3 Moreover, by restoring the public confidence EPA so badly needs, more balanced executive oversight could also help diminish the trend toward increasing legislative constraints on agency discretion.

\section{II}

\section{The Evolution of Executive Office Oversight}

Each of the five presidents who have served during EPA's twenty-year history has required his Executive Office to conduct some form of review of executive agency rulemaking. ${ }^{4}$ These regulatory review programs were a direct response to the rapid growth of federal environmental regulation in the early 1970 s. ${ }^{5}$

3. US Const, Art II, § 3.

4. Each administration has had its own names for regulatory review and the analyses it has required of agencies. The Nixon Administration called its program Quality of Life ("QOL") review. Memorandum from George P. Shultz, Agency Regulations, Standards, and Guidelines Pertaining to Environmental Quality, Consumer Protection, and Occupational and Public Health and Safety (Oct 5, 1971). While President Ford continued the QOL program, he also required agencies to prepare Inflation Impact Statements ("IISs") as part of the administration's "Whip Inflation Now" ("WIN") program. Exec Order 11821, 3 CFR 926 (1971-1975 Comp). In December 1976, the IISs were renamed Economic Impact Analyses ("EIAs") and bore that name until December 1977 when President Carter replaced them with Regulatory Analyses. Review under the Carter Administration's program was conducted by an interagency body called the Regulatory Analysis Review Group. Improving Government Regulations, Exec Order 12044, 3 CFR 152 (1979). The Reagan Administration's program required agencies to perform Regulatory Impact Analyses reviewed by the Office of Management and Budget's Office of Information and Regulatory Affairs. The Bush Administration has continued this program, which now authorizes appeals to the Council on Competitiveness rather than to the presidential Task Force on Regulatory Relief.

5. The environmental legislation Congress had enacted during the 1960 s generally did not authorize federal regulation, but rather confined the federal role to providing modest grants to assist states with environmental planning. Following enactment of the National Environmental Policy Act ("NEPA"), Pub L No 91-190, 83 Stat 853 (1970), codified at 42 USC $\$ 4321$ (1982), which was signed into law on January 1, 1970, Congress enacted nearly all the ocher significant federal environmental legislation in a ten-year burst of activity. These statutes mandated the establishment of comprehensive, national regulations to control virtually all forms of pollution and to regulate toxic substances and hazardous waste. See, for example, the Clean Air Amendments of 1970 (Clean Air Act), Pub L No 91-604, 84 Stat 1676 (1970), codified at 42 USC $\$ 7401$ (1982); the Federal Water Pollution Control Act Amendments of 1972 (Clean Water Act), Pub L No 92-500, 86 Stat 816, codified at 33 USC \& 1251 (1982); the Safe Drinking Water Act, Pub L No 93-523, 88 Stat 1660 (1974), codified at 42 USC $\$ 300 f(1982)$ to $300 j-11$ (1974); the Toxic Substances Control Act ("TSCA"), Pub L No 94-469, 90 Stat 2003 (1976), codified at 15 USC \& 2601 (1982); the Resource Conservation and Recovery Acc ("RCRA"), Pub L No 94-580, 90 Stat 2795 (1976), codified at 42 USC $\S 6901$ (1982); and the Comprehensive Environmental Response, Compensation and Liability ACt ("CERCLA"), 42 USC \& 9601 (1982). 
While the combination of forces that stimulated this extraordinary burst of legislative activity is complex, ${ }^{6}$ environmental protection clearly had become a politically irresistible cause. ${ }^{7}$ This development is reflected in the actionforcing structure of the environmental laws. Beginning with the Clean Air Act in 1970, environmental legislation required the establishment of national regulations, often by specified deadlines, with both regulations and deadlines enforceable by citizen suits. ${ }^{8}$ While the Clean Air Act was in many ways "the polar extreme from the National Environmental Policy Act ("NEPA")," both were founded on the conviction that action-forcing legislation was necessary to overcome agency resistance to change. ${ }^{9}$ NEPA sought to effect change from within agencies by mandating changes in their decisionmaking processes; the Clean Air Act sought to force action by dictating the kinds of regulations agencies were required to issue by certain deadlines. White House concern over the potential impact of those regulations on industry stimulated the creation of the regulatory review programs.

\section{A. Regulatory Review in the Nixon Administration}

By 1969, the enormous popularity of environmental issues had convinced the Nixon Administration that sweeping new environmental legislation was inevitable. To help the administration develop a comprehensive policy on the environment, President Nixon created the Environmental Quality Council, a cabinet committee coordinated by the White House Office of Science and Technology. ${ }^{10}$ When it became apparent in the summer of 1969 that the divided attentions of cabinet members and their lack of environmental

6. See, for example, Robert L. Rabin, Federal Regulation in Historical Perspective, 38 Stan L Rev $1189,1278-95$ (1986) (citing the climate created by public opposition to the Vietnam War but noting that environmental legislation "was not the product of a social movement for reform, nor even the outcome of pluralistic, interest group politics," id at 1293); E. Donald Elliot, Bruce A. Ackerman \& John C. Millian, Toward a Theory of Statutory Evolution: The Federalization of Environmental Law, $1 \mathrm{~J}$ L Econ \& Org 313 (1985) (describing federal environmental legislation as the product of "lawmaking [as] characterized by unrestrained competition among presidential aspirants for the credit to be gained from legislation assuring the public of a cleaner world," id at 328); Christopher C. DeMuth, Constraining Regulatory Costs-Part One: The White House Review Programs, 4 Regulation 13, 14 (Jan/Feb 1980 ), noting that reforms in Congress's committee structure and seniority system had eliminated obstacles that previously had blocked enactment of new federal programs.

7. Former White House aide John Whitaker writes that "hysteria" is the only way "to describe the Washington mood on the environment issue in the fall of 1969." John C. Whitaker, Striking a Balance: Environment and Natural Resources Policy in the Nixon-Ford Years 27 (Am Enterprise Inst for Pub Policy Research, 1976) (emphasis in original). Describing the political climate that prevailed in 1970, Theodore White has written that "the environment cause had swollen into the favorite sacred issue of all politicians, all $\mathrm{TV}$ networks, all good-willed people of any party." Theodore $\mathrm{H}$. White, The Making of the President 1972. 45 (Atheneum, 1973).

8. Elliot, Ackerman, and Millian note that industry opposition to national regulation was weakened by fears that states would adopt their own conflicting state standards. They argue that the absence of well-organized environmental lobbyists at the federal level actually contributed to more stringent regulatory legislation because there was no coherent coalition that industry could force to compromise. Elliot, Ackerman \& Millian, $1 \mathrm{~J} \mathrm{~L} \mathrm{Econ} \mathrm{\&} \mathrm{Org} \mathrm{at} 313$ (cited in note 6).

9. Rabin, 38 Stan L Rev at $1288-89$ (cited in note 6).

10. The Environmental Quality Council was created on May 29, 1969. Exec Order 11472, 3 CFR 792 (1966-70 Comp). 
expertise were precluding progress in developing a comprehensive policy, ${ }^{11}$ President Nixon established a task force composed of high-level agency staff with experience in environmental issues. The task force was charged with developing the President's first environmental message to Congress, which he delivered in February 1970.

Following the enactment of NEPA and the delivery of the President's environmental message, Nixon was eager to reassure a corporate community concerned about the cresting wave of environmental regulation. To ensure that industry's input was considered in regulatory decisionmaking, the President issued an executive order on April 9, 1970, creating the National Industrial Pollution Control Council ("NIPCC"). 12 The stated purpose of NIPCC, which was composed of sixty-three top corporate executives appointed by the Secretary of Commerce, ${ }^{13}$ was to "allow businessmen to communicate regularly with the President, the Council on Environmental Quality and other governmental officials and private organizations" with respect to environmental matters and regulatory initiatives. ${ }^{14}$ Operating out of the Department of Commerce, the council played a prominent role in lobbying the White House to use the regulatory review process to block or weaken environmental regulations. ${ }^{15}$

The newly enacted NEPA had sharpened the White House's focus on environmental issues by creating a Council on Environmental Quality ("CEQ") in the Executive Office of the President. 16 NEPA directed CEQ to assist the president in preparing an annual Environmental Quality Report and "to review and appraise the various programs and activities of the Federal government" in implementing Congress's newly declared national

11. Whitaker, Striking a Balance at 28 (cited in note 7 ).

12. Exec Order No 11523, 3 CFR 915 (1966-70 Comp).

13. All 63 members of the NIPCC were chairmen of the board or chief executive officers of major corporations. Implementation of the Clean Air Act Amendments of 1970, Hearings before the Subcommittee on Air and Water Pollution of the Senate Committee on Public Works, 92d Cong, 2d Sess 577-78 (1972) ("1970 Clean Air Act Hearings"); see also William H. Rodgers, Jr., The National Industrial Pollution Control Council: Advise or Collude?, 13 B C Indust \& Comm L Rev 719, 720 (1972).

14. Statement by the president on Establishing the National Industrial Pollution Control Council, 6 Wkly Comp Pres Doc 502 (April 9, 1970). The executive order that created the council designated five functions for it to perform: (1) to survey industry plans relating to environmental quality, (2) to identify problems of the environmental effects of industrial practices, (3) to provide a liaison among members of the business and industrial community on environmental quality matters, (4) to encourage business to improve the quality of the environment, and (5) to advise on the environmental policies of government agencies that affect industry when they are referred to it by the secretary of commerce or the chairman of the CEQ. Exec Order 11523, 3 CFR 915 (1966-70 Comp).

15. Henry J. Steck, Private Influence on Environmental Policy: The Case of the National Industrial Pollution Control Council, 5 Envir L 241 (1975). While noting congressional concern over having the "fox in the chicken coop," former White House aide John Whitaker argues that the Council performed a worthwhile function by improving communication between government and corporate engineers concerning pollution control technology. Whitaker, Striking a Balance at 40 (cited in note 7). The NIPCC program eventually was terminated in 1975 by the Ford Administration after Congress refused to provide funding for its staff. Steck, 5 Envir L at 279-80 (cited in this note).

16. 42 USC $\$ 4342$ (1982). Whitaker notes that the creation of CEQ eliminated some of the shortcomings of the task force approach to environmental policy, including conflicts between the interests of the departments represented by task force members. Whitaker, Striking a Balance at 30 (cited in note 7 ). 
environmental policy. ${ }^{17}$ Although President Nixon had not supported the creation of CEQ,${ }^{18}$ he publicly embraced the agency after NEPA's enactment. Referring to CEQ as "the keeper of our environmental conscience and a goad to our ingenuity," the president declared that "it will have responsibility for insuring that all our programs and actions are undertaken with a careful respect for the need of environmental quality."19

While Congress had created CEQ to ensure that executive agencies implemented NEPA, it was widely recognized that a major reorganization of the executive branch was necessary to consolidate regulatory responsibilities for environmental protection. Shortly after NEPA's enactment, the Nixon Administration considered a proposal to create an agency called the Department of Environment and Natural Resources that would replace the Department of Interior and would consolidate the environmental and natural resource management responsibilities of various federal agencies. ${ }^{20}$ Roy Ash, the chairman of the president's Advisory Council on Executive Organization (known popularly as the Ash Council), initially rejected a staff recommendation to create an independent agency devoted solely to environmental protection. Ash reportedly believed that a department that combined competing interests for environmental protection and resource development would be easier for the White House to control because it would be less likely to be a strong advocate of environmental or development interests. ${ }^{21}$

A bipartisan group of congressmen, however, already had endorsed the creation of a separate agency devoted to environmental protection. ${ }^{22}$ In addition, existing agencies that would lose programs in a reorganization forcefully opposed the creation of a superagency that would merge environmental protection and resource development programs. ${ }^{23}$ The Ash

17. 42 USC $\$ 4344(1)$, (3) (1982).

18. President Nixon's creation of Environmental Quality Council, a cabinet committee, had been viewed as an unsuccessful White House effort to block the creation of CEQ. E. W. Kenworthy, Environmental Council Dubious of SST Program, NY Times 74, Col 3-5 (Feb 6, 1970).

19. Robert B. Semple, Jr., President Offers Plan for Cleanup of Air and Water, NY Times 1 col 8, 33 col 1 (Feb 11, 1970). Nixon viewed CEQ as a vehicle for highlighting his administration's commitment to environmental protection. The president directed CEQ to develop a federal research program to invent a pollution-free alternative to the internal combustion engine within five years and to establish a federal bounty payment program to promote the scrapping of old automobiles. Id.

20. Marc K. Landy, Marc J. Roberts \& Stephen R. Thomas, The Environmental Protection Agency: Asking the Wrong Questions 30-32 (Oxford U Press, 1990) ("EPA: Asking the Wrong Questions").

21. Alfred Marcus, Environmental Protection Agency, in James Q. Wilson, ed, The Politics of Regulation 267, 294-95 (Basic Books, !980).

22. Alfred A. Marcus, EPA's Organizational Structure, 54 L \& Contemp Probs at 5, 9-22 (Autumn 1991).

23. The only enthusiastic supporter of the Ash Council reorganization plan was Secretary of Interior Walter Hickel, whose agency stood to gain many new programs. John Quarles speculates that President Nixon's ultimate decision to reject the Ash Council recommendation may have been colored in part by Nixon's anger at Hickel for his criticism of the White House reaction to the Ohio National Guard's killing of four Kent State University students protesting the invasion of Cambodia. John Quarles, Cleaning Up America: An Insider's View of the Environmental Protection Agency 17-19 (Houghton Mifflin, 1976). See also Whitaker, Striking a Balance at 56 (cited in note 7). 
Council and President Nixon ultimately rejected the superagency proposal in favor of creating by executive order a separate Environmental Protection Agency.

The most important rationale for creating a separate agency was the wide agreement among government officials on the importance of having an independent entity establish regulatory standards. Like the environmental legislation that it has been charged with implementing, EPA was expressly structured to overcome barriers to aggressive agency action. In announcing the creation of EPA, President Nixon stressed the importance of establishing a new, single-mission agency that could serve as a strong, independent, and objective source of policy. ${ }^{24}$ The importance of EPA's independence was repeatedly stressed by a bipartisan group of witnesses who testified before congressional committees in support of President Nixon's reorganization plan. ${ }^{25}$ EPA went into operation on December 2, 1970 in accordance with the president's plan.

Among EPA's first responsibilities was implementation of the new regulatory provisions in the Clean Air Act of 1970. Alarmed by the potential cost of such regulations, the Commerce Department and the Office of Management and Budget ("OMB") sought a mechanism to restrain EPA's regulatory impulses. Secretary of Commerce Maurice Stans persuaded President Nixon's chief domestic policy aide, John Ehrlichman, to establish a task force to examine how to control EPA's regulatory activities. ${ }^{26}$ OMB, which had authority over the budgets of executive agencies, was alarmed by the size of EPA's supplemental budget requests and by the perception that

24. In his statement creating EPA, President Nixon noted that each existing “department also has its own primary mission-such as resource development, transportation, health, defense, urban growth or agriculture-which necessarily affects its own views of environmental questions." Excerpts from President's Message on Reorganization of Environmental Agencies, NY Times 14 (July 10, 1970). He noted that "if the critical standard-setting functions were centralized within any one existing department, it would require that department constantly to make decisions affecting other departments-in which, whether fairly or unfairly, its own objectivity as an impartial arbiter could be called into question." Id. Thus, he concluded, "in this case a strong, independent agency is needed." Id. John Quarles notes that it is puzzling that Nixon, who was not a strong advocate of environmental protection, was responsible for EPA's creation. He attributes this fact to the enormous political popularity of environmental protection in 1970. Quarles, Cleaning Up America at 20 (cited in note 23 ).

25. Testifying in support of President Nixon's plan, Senator Edmund Muskie, chairman of the principal Senate committee concerned with environmental protection, emphasized the importance of EPA's autonomy and single-mission focus: "If the control of pollution is assigned to those responsible for the promotion of polluting activities at the same time, we compromise our goal of environmental protection. ... The agency which sets environmental quality standards must have only one goal-protection of this and future generations against changes in the natural environment which adversely affect the quality of life." [Status of the Programs and Policies of the Environmental Protection Agency], Hearing before the Subcommittee on Environmental Pollution of the Senate Committee on Public Works, 95th Cong, 1st Sess 13-14 (1977) ("Status Hearing"). Russell Train, chairman of the CEQ, noted that "the public is increasingly questioning the vesting of promotional and regulatory powers in the same agency," and concluded that EPA, "by assuming these regulatory functions, should help restore public confidence in our ability to control pollution from these sources." Id at $16,19$.

26. George C. Eads \& Michael Fix, Relief or Reform? Reagan's Regulatory Dilemma 47 (Urban Inst Press, 1984). 
EPA's rulemaking responsibilities could dictate the size of the agency's budget.

The complaints of the Commerce Department and OMB fell on receptive ears; at that time President Nixon was continuing an effort to reorganize substantially the entire executive branch in order to increase its accountability to him. ${ }^{27}$ The President had created OMB out of the old Bureau of the Budget, renaming it to reflect the new management role he wanted it to exercise over executive agencies. In his 1971 State of the Union message, the President proposed creating four new superagencies to replace existing domestic cabinet agencies. ${ }^{28}$ When asked why the newly created EPA would not be included in any of the proposed new superdepartments, OMB Director George Shultz explained that "the basic idea is that it has a regulatory function and, therefore, ought to have a degree of independence from the programmatic efforts of the various departments."29

While publicly emphasizing the importance of EPA's independence, OMB was acting to assert greater control over EPA's regulatory activities. On May 21, 1971, Shultz sent EPA Administrator William Ruckelshaus a letter arguing that OMB had authority to review and clear EPA regulations. ${ }^{30}$ Based on this concept, President Nixon established a "Quality of Life" ("QOL") regulatory review program under the direction of OMB.

The QOL program required that agencies submit regulatory proposals to OMB for pre-publication review by other relevant agencies to ensure that adequate consideration was given to the economic impact of regulation. ${ }^{31}$ OMB was made responsible for mediating conflicts between agencies, but it was not given ultimate decisionmaking power. A proposal that would have shifted to OMB explicit decisionmaking authority had been rejected because of concern over legal and political obstacles. ${ }^{32}$ Instead, the QOL review process emphasized interagency comment by blocking the issuance of proposed regulations until the concerns of other interested agencies were fully aired and considered.

27. As part of his efforts to exert greater control over the bureaucracy, President Nixon also was engaged in a spirited confrontation with Congress concerning his assertion of authority to impound funds appropriated by Congress. Claiming that his power to withhold appropriated funds was unlimited, the president "used the issue aggressively to provoke his political opponents who controlled Congress." James L. Sundquist, The Decline and Resurgence of Congress 203 (Brookings Inst, 1981).

28. When Congress balked at President Nixon's efforts to effect a massive reorganization of the executive branch, he attempted to implement this program administratively by giving certain cabinet officers the title of "Counsellors to the President." These reorganization plans, which ultimately failed as the Watergate scandal engulfed the Presidency, are discussed in Richard P. Nathan, The Plo that Failed: Nixon and the Administrative Presidency (John Wiley \& Sons, 1975).

29. Reorganization of Executive Departments, HR 6959, HR 6960, HR 6961, and HR 6962, Hearings before a Subcommittee of the House Committee on Govt Operations, 92d Cong, lst Sess $178(1971)$

30. Eads \& Fix, Relief or Reform? at 47-48 (cited in note 26).

31. Landy, Roberts \& Thomas, EPA: Asking the Wrong Questions at 37 (cited in note 20)

32. Eads \& Fix, Relief or Reform? at 48 (cited in note 26). 
Under the QOL process, agencies were to submit "significant" proposed rules to OMB thirty days before draft publication, along with an analysis of the rule's objectives, alternatives, and expected costs and benefits. ${ }^{33}$ OMB then solicited comments from other agencies, which were forwarded to the agency proposing the rule. A similar process, focusing on public comments and any new issues raised during the rulemaking, was to be followed twenty days before the publication of final rules.

The Clean Air Act provided the initial impetus for regulatory review, but NEPA served as the model for the process by which QOL review was conducted. ${ }^{34}$ Rather than attempting to dictate the substance of agency decisions, NEPA sought to change the decisionmaking process by requiring agencies to prepare analyses of the environmental consequences of alternative courses of action. ${ }^{35}$ While the trend toward requiring more systematic agency analysis of alternatives can be traced to budgetary planning experiments initiated in the early $1960 \mathrm{~s},{ }^{36}$ NEPA institutionalized such a requirement and made it enforceable by the public. ${ }^{37}$ In similar fashion, the QOL program required agencies to prepare and consider analyses of the economic impacts of regulation prior to proposing regulatory actions.

The QOL review process stimulated EPA's development of its own internal review process as a means to assist the agency in justifying its regulatory actions to external reviewers. ${ }^{38}$ EPA created the Office of Policy, Planning and Evaluation ("OPPE") and staffed it with economists who prepared analyses of the economic impacts of regulatory initiatives. OPPE helped EPA articulate alternative regulatory options and substantially improved the quality of the agency's regulatory analyses. Thus, the creation

33. Three categories of regulations were to be subjected to QOL review: (1) actions expected to have a significant impact on the policies, programs, and procedures of other agencies, (2) actions expected to impose significant costs or to remove significant benefits from nonfederal sectors, and (3) actions expected to increase federal funding requirements beyond the levels provided for in the most recent budget requests sent to Congress. Office of Management and Budget Plays Critical Part in Environmental Policymaking, Faces Little External Review, 7 Envir Rptr (BNA) 693 (1976).

34. Although the influence of NEPA on the evolution of regulatory review has been largely unexplored, the parallels between NEPA's environmental impact statement requirement and the forms of regulatory analyses required by the regulatory review programs have been sufficiently striking to elicit comment. See Serge Taylor, Making Bureaucracies Think: The Environmental Impact Statement Strategy of Administrative Reform 284 (Stanford U Press, 1984); Thomas O. McGarity, Regulatory Analysis and Regulatory Reform, 65 Tex L Rev 1243, 1247-48 (1987).

35. As Robert Rabin has explained, although "NEPA may have been intended as a largely symbolic enactment, [it] represented a wholly different strategy for controlling administrative discretion." Unlike previous reform efforts such as the Administrative Procedure Act, "NEPA anticipated an altered process of decision rather than simply better procedures for decision; the environmental impact statement was to be 'action forcing' in that every federal regulatory agency was to reassess its mandate in view of the environmental consequences of any major decision it might reach." Rabin, 38 Stan L Rev at 1284, 1287 (cited in note 6).

36. See Alice M. Rivlin, Systematic Thinking for Social Action (Brookings Inst, 1971), discussing planning-programming-budgeting concept introduced in the Defense Department in 1961, which became an influential idea for improving domestic policy in part through the efforts of Charles Schultz.

37. For an analysis of the impact of NEPA on agency decisionmaking, see Taylor, Making Bureaucracies Think (cited in note 34 ).

38. Marcus, Environmental Protection Agency at 289-90 (cited in note 21). 
of an interagency review process stimulated a significant improvement in EPA's analytical capabilities.

Although the QOL review process was supposed to apply to environmental, consumer protection, and health and safety regulations, only EPA regulations were actually subjected to QOL review. Urged on by the corporate executives who comprised NIPCC, the Commerce Department used the QOL process to raise vigorous challenges to EPA regulatory proposals. The process featured "heated arguments between EPA and the Department of Commerce, its principal antagonist," with the "main 'analysis" " of the reviews being "industry-prepared information presented by the Commerce Department." 39 OMB sometimes played "a mediating role" and sometimes "press[ed] its own institutional interests (which generally were opposed to EPA's)."40

While the Commerce Department used the QOL review process to oppose environmental regulation aggressively, the White House also kept a close watch on EPA's activities. White House officials occasionally intervened directly in environmental policy decisions. At the same time, however, EPA Administrator Ruckelshaus sought to enhance the agency's independence from the White House by courting favorable media attention. For example, a presidential aide asked EPA to seek a stay of a court order EPA had won in one of its first enforcement actions after the affected company's president, a politically important Republican, had complained publicly that jobs would be lost. ${ }^{41}$ The White House backed off, however, after a newspaper report of the incident triggered an immediate congressional hearing and a public threat by Administrator Ruckelshaus that he would resign "if environmental decisions are overruled because of political considerations." 42

While publicity could help blunt direct White House intervention, EPA did not always prevail in the secretive QOL review process. Environmentalists charged that QOL review was used to weaken regulations crucial to EPA's early implementation of the Clean Air Act. In February 1972, a Senate committee heard charges that OMB review had resulted in eleventh hour changes that severely weakened EPA's guidelines for state implementation plans ("SIPs") under the Clean Air Act. The final guidelines promulgated by EPA were said to be substantially less stringent than the final regulations EPA had prepared and submitted to OMB for QOL review. ${ }^{43}$ In a statement that now sounds like a familiar refrain, an attorney from the Natural Resources Defense Council told the Senate committee:

The White House Office of Management and Budget is reviewing in secrecy every major action of the Environmental Protection Agency. The public is completely excluded from this review, but the most antienvironmental Federal agencies, such as

39. Eads \& Fix, Relief or Reform? at 49 (cited in note 26).

40. Id.

41. This incident is described in Quarles, Cleaning Up America at 58-76 (cited in note 23) (action against Armco Steel for polluting the Houston Ship Channel).

42. Id at $68-70$.

43. 1970 Clean Air Act Hearings at 4 (cited in note 13). 
the Commerce Department and the Federal Power Commission, appear to have full access to it. These agencies, acting as spokesmen for industrial interests, have effective power to veto EPA's actions. Now becoming routine, OMB review is gelding the clean air amendments. ${ }^{44}$

Responding to this charge, EPA Administrator William Ruckelshaus admitted that the guidelines had been changed after QOL review, but he branded as "categorically false" the notion that OMB had dictated the changes. ${ }^{45}$ In an effort to turn the tables on the committee, Ruckelshaus noted that members of Congress also had suggested changes in the final guidelines. ${ }^{46}$ Sounding a theme often to be repeated in defense of OMB review, Ruckelshaus asserted that he, not OMB, had made the final decision about changes in the guidelines. ${ }^{47}$ Confronted with a chart of the SIP process prepared by EPA that had the words "OMB approval" as the last step in the process, Ruckelshaus branded it "erroneous." 48

Called back for a second day of hearings, the EPA Administrator admitted that White House aides occasionally asked him to respond to complaints from corporate officials. But he denied that a letter he had sent in response to such a complaint was improper, even though it appeared to moderate EPA's position concerning regulation of a Montana copper smelter. ${ }^{49}$ The Administrator complained that by airing such charges the committee had damaged the agency's credibility by reinforcing public mistrust. ${ }^{50}$ While stating that he welcomed QOL review, Ruckelshaus emphasized that officials of the Executive Office were not making decisions for EPA and "[i]f they were, I would be breaking the law, and I would not function as Administrator of this Agency if I let them do so." 51 The Administrator observed that QOL review was beneficial because it permitted EPA to take advantage of the "expertise that exists in other agencies of Government," and it informs the other agencies of the reasons for EPA's actions. ${ }^{52}$

EPA's retention of final authority for regulatory decisions subject to QOL review was confirmed by OMB Director George Shultz. While he did not appear at the hearing, Shultz sent a note advising the committee that "EPA has final authority on plans for implementation of air quality standards under the Clean Air Act Amendments of 1970."53

Although Ruckelshaus had assured Congress that he had the ultimate authority over regulatory matters, the White House was acting to give OMB

44. Id at 4 (statement of Richard Ayres, Natural Resources Defense Council).

45. Id at 230 .

46. Id at 231 .

47. Id at 243 ("OMB did not get any final crack at the regulation. OMB is nothing more than a conduit to insure that other Federal agencies who want to comment on any regulation that we might issue are given that right to comment. The final determination as to what ought to be in the guidelines is mine.").

48. Id at 238-39.

49. Id at 297-306.

50. Id at 325 .

51. Id.

52. Id at 325-26.

53. Id at 338 . 
greater authority to review agency communications with Congress. On July 31, 1972, OMB Circular A-19 was promulgated, which required agencies to submit proposed testimony, reports, or legislation to OMB prior to their transmission to Congress. ${ }^{\mathbf{4}}$

Although Ruckelshaus defended regulatory review to the outside world, conflict between EPA and the Executive Office was not infrequent. It has been reported that during President Nixon's reelection campaign, his campaign chairman, Maurice Stans, cited the potential threat a vigorous EPA posed when soliciting campaign contributions from corporate officials. ${ }^{55}$ Thus, it is understandable that EPA officials were concerned about the agency's independence in the wake of President Nixon's landslide victory. Quarles reports that as a condition for remaining as EPA administrator after the 1972 election, Ruckelshaus requested written assurances from Nixon that the EPA administrator would retain ultimate authority for EPA policy decisions. ${ }^{56}$ Despite President Nixon's verbal assent, EPA "bargained in vain with OMB to spell out the change in writing." 57

Russell Train also insisted upon written assurances that the EPA administrator retained ultimate policy authority when he was appointed to succeed Ruckelshaus in the summer of 1973.58 In his confirmation hearing, Train emphasized that it was "of crucial importance that EPA establish and maintain at all times a strongly independent role." 59 Train voiced qualified support for QOL review, by calling it "a perfectly appropriate part of the decisionmaking process" to the extent that it elicits the view of other agencies, but only when it is conducted, controlled, and directed by the EPA administrator.60 He announced that he had "already discussed this matter with responsible officials in OMB" and that he had "full concurrence that all processes of interagency comment, review, and suggestion with respect to proposed regulatory decisions by the Administrator of EPA will be directed by the Administrator of EPA and be conducted by him and on his behalf, not controlled by the Office of Management and Budget." 61

54. 7 Envir Rptr (BNA) at 695 (cited in note 33).

55. James Q. Wilson, The Politics of Regulation, in Wilson, ed, The Politics of Regulation 357, 388 (cited in note 21). Noting that President Nixon was largely unsuccessful in his efforts to curb EPA's aggressive commitment to strict environmental standards, Wilson suggests that "a vigorous EPA was more valuable to Nixon than a passive one." Id. As Wilson explains: "There is a fine line between bribery and extortion." Id.

56. Quarles, Cleaning up America at 117-19 (cited in note 23). Landy, Roberts, and Thomas report that, prior to accepting a position as EPA administrator in 1973, Russell Train insisted on obtaining written confirmation that he would have final authority over all EPA regulations. Landy, Roberts \& Thomas, EPA: Asking the Wrong Questions at 38 (cited in note 20).

57. Quarles, Cleaning Up America at 119 (cited in note 23).

58. Id at 119.

59. Nomination of Russell E. Train, Hearing before the Senate Committee on Public Works, 93d Cong, 1st Sess 3 (1973) ("I assure you that I, as Administrator, will make the final decisions. I will seek and welcome comments and suggestions both from within Government and from the public, but the final decisions will be mine.").

60. Id at 8 .

61. Id at 8. Train also pledged close cooperation with Senator Muskie's committee, which expressed a desire to perform detailed oversight of EPA's operations. As Senator Muskie told the 
Train's pledge that he would control the regulatory review process did not insulate him from vigorous White House pressure on major regulatory decisions. John Quarles has provided a detailed account of unrelenting pressure from the White House to weaken EPA's initial regulations limiting the lead content of gasoline. ${ }^{62}$ Faced with a court-ordered deadline to promulgate the regulations, Train had submitted draft regulations to OMB for QOL review three weeks before the deadline. At an interagency meeting held to discuss the regulations five days before the deadline, EPA stated that it would proceed with the regulations despite opposition from other agencies such as the Department of the Interior. Throughout the two days preceding the deadline, a flurry of phone calls and White House meetings transpired as presidential aides, OMB, and Interior officials sought to block Train from promulgating any meaningful limits on the lead content of gasoline. EPA ultimately promulgated the regulations it wanted only after agreeing, two hours before the press conference announcing the regulations, to accept OMB's request to delay the final target date for the lead phasedown program by one year. ${ }^{63}$

Quarles also recounts a wide range of disputes that occurred between EPA and the White House over legislative and budgetary issues. In January 1974 , in response to economic pressures caused by the Arab oil embargo, the Nixon Administration developed proposed legislation to weaken the Clean Air Act. White House staff engaged in a bitter dispute with EPA officials in an effort to get EPA to endorse the proposal. EPA Administrator Russell Train refused to support the legislation and threatened to resign. The White House staff was forced to back down, increasing Train's reputation as a strong advocate of environmental protection who was independent of White House control. ${ }^{64}$ Regardless of the impact of such incidents, Train's independence undoubtedly increased due to the growing Watergate scandal that weakened President Nixon and ultimately forced him to resign. ${ }^{65}$

\section{B. Regulatory Review in the Ford Administration}

The Quality of Life review program was continued during the administration of President Ford, who took office following President Nixon's resignation in August 1974. Concerned about rising inflation, President Ford expanded the scope of regulatory review by broadening the subjects of

administrator-designate, "I don't want to be sitting on your lap as you are making these decisions, but I would like to think I know what is going on and that you share the same view." Id at 8-9. Train noted, however, that as a member of the executive branch he also remained independent of Congress. Id at 54.

62. See Quarles, Cleaning Up Amenca at 117-42 (cited in note 23).

63. Id at 138 .

64. Id at 141 .

65. As Robert Sansom, who was EPA's assistant administrator for air pollution control programs, notes, Train survived as EPA administrator "because Richard Nixon did not." Robert Sansom, The New American Dream Machine: Toward a Simpler Lifestyle in an Environmental Age 25 (Anchor Press, 1976). 
regulatory analyses and by entrusting a new Executive Office agency with responsibility for reviewing them.

Although the Nixon Administration had sought to moderate selected regulations through QOL review, federal regulatory activity had grown rapidly in the early 1970 s. Seven new regulatory agencies had been created, including EPA, OSHA, and the Consumer Product Safety Commission. Between 1970 and 1974, twenty-nine major regulatory statutes had been enacted and the number of pages in the Federal Register had more than doubled from 20,036 to 42,422 per year. ${ }^{66}$

Ford's staff was less directly involved in efforts to influence regulatory decisions. A transition team that advised him had expressed concern over OMB's growing influence over policymaking by agencies. It concluded that "OMB was becoming too involved in departmental policy processes, and limiting the department's ability to come up with innovative ideas. It was moving into departments at $[\mathrm{t}]$ oo low a level, and preventing the free flow of ideas." 67 Perhaps motivated by such concerns, the Ford Administration shifted the focus of regulatory review away from prepublication review toward review of proposed regulations during the public comment period. ${ }^{68}$

Concerned about the growing inflation problem, President Ford broadened the type of analyses agencies were required to undertake. In November 1974, he issued Executive Order 11821, which required executive agencies to prepare "inflation impact statements" prior to issuing major rules. ${ }^{69} \mathrm{OMB}$ instructed agencies to include in the inflation impact statements "an analysis of the principal cost or other inflationary effects of the action," a comparison of these with "the benefits to be derived from the proposed action," and a review of alternatives that were considered. ${ }^{70}$

A new agency in the Executive Office, the Council on Wage and Price Stability ("CWPS"), was given the role of coordinating agency compliance with the executive order.71 Unlike QOL review, CWPS's review occurred during the public comment period, and it produced written statements by CWPS that were added to the rulemaking record. CWPS was not authorized

66. James C. Miller, III, Lessons of the Economic Impact Statement Program, 1 Regulation 14,15 (July/Aug 1977).

67. Quoted in a question submitted by Senator Ribicoff to OMB Director designate Thomas B. Lance in Nominations of Thomas B. Lance and James T. McIntyre, Jr., Hearings before the Senate Committee on Governmental Affairs, 95th Cong, 1st Sess 30 (1977) ("Nomination Hearings of Lance and McIntyre"').

68. George C. Eads, White House Oversight of Executive Branch Regulation, in Eugene Bardach \& Robert A. Kagan, eds, Social Regulation: Strategies for Reform 177, $192-93$ (Inst for Contemp Stud, 1982).

69. Exec Order 11821, 3 CFR 926 (1971-1975 Comp). This program was later incorporated into a revised Executive Order 1 1949, issued by the lame duck Ford Administration on December 31, 1976. This executive order renamed the basic regulatory analysis document an "Economic Impact Statement." 42 Fed Reg 1017 (1977).

70. Evaluation of the Inflationary Impact of Major Proposals for Legislation and the Promulgation of Regulations or Rules, OMB Circular No A-107 (Jan 28, 1975).

71. Council on Wage and Price Stability Act, Pub L No 93-387, 88 Stat 750 (1974), codified at 12 USC $\$ 1904$ (1982). 
to block agency rulemaking action; rather, it sought to influence the agency through its testimony during the rulemaking proceeding. CWPS representatives often testified in person at agency hearings. While CWPS's activities generated considerable controversy, Congress expressly endorsed CWPS's participation in rulemaking proceedings when it amended CWPS's enabling act in $1975 .{ }^{72}$

Unlike QOL review, which had focused exclusively on EPA during the Nixon Administration, CWPS reviewed the activities of a wide variety of agencies, but focused most of its attention on economic regulations issued by the Civil Aeronautics Board and the Interstate Commerce Commission. Only eighteen of the 180 public filings made by CWPS between December 1974 and November 1978 involved EPA regulations. ${ }^{73}$

Although few substantive changes in regulations can be credited directly to the Ford Administration's requirement that agencies prepare Inflation Impact Statements, the program did help stimulate expanded use of economic analysis by regulatory agencies. When CWPS solicited public comment on the program, most agencies found the analyses helpful and supported continuation of the program. ${ }^{74}$ However, the analyses themselves were of uneven quality and often were prepared after a regulation had been developed in order to justify the agency's decision. ${ }^{75}$

The Ford Administration's continuation of QOL review was more controversial than its new Inflation Impact Statement requirement. Reviewing OMB's management of the QOL review program, the Environment Reporter concluded in 1976 that "[OMB] plays an influential part in shaping federal environmental policies, frequently with little public awareness or understanding of its role." 76 Repeating some of the same criticisms made during the Nixon Administration, the report noted that EPA officials believed that their agency had been unfairly "singled out" for QOL reviews and that

72. Congress confirmed CWPS's authority to "intervene and otherwise participate on its own behalf in rulemaking, ratemaking, licensing and other proceedings before any of the departments and agencies of the United States in order to present its views as to the inflationary impact that might result from the possible outcomes of such proceedings." Council on Wage and Price Stability Act Amendments of 1975, Pub L No 94-78, § 4, 89 Stat 411 (1975), codified at 12 USC § 1904 (1982) See Presidential Management of Rulemaking in Regulatory Agencies 9 (Natl Acad Pub Admin, 1987) ("NAPA, Presidential Management").

73. Cost of Government Regulations to the Consumer, Hearings before the Subcommittee for Consumers of the Senate Committee on Commerce, Science and Transportation, 95th Cong, 2d Sess 53-55 (1978) ("Cost Hearings"). A total of 65 Inflation Impact Statements and Economic Impact Analyses were prepared between December 1975 and April 1977. Fifty-seven involved proposed regulations and eight involved proposed legislation. EPA prepared such analyses for 17 proposed regulatory actions between July 1975 and January 1977. Miller, 1 Regulation at 14, 20-21 (cited in note 66 ).

74. Miller, I Regulation at 17 (cited in note 66) (noting that only the Department of Agriculture and the Federal Energy Administration opposed continuation of the program, and that organized labor had criticized the program for delaying OSHA's issuance of regulations).

75. Id at 18 (noting that EPA and the Department of Transportation "devoted substantial analytical resources to the task" of performing economic analyses, while many other agencies did not, id at 16 ).

76. 7 Envir Rptr (BNA) at 693 (cited in note 33). 
most other federal agencies generally used the review process to try to weaken EPA regulations.

President Ford was not known as a strong advocate of environmental regulation. He supported measures to relax environmental regulations, particularly auto emission controls, and twice vetoed legislation requiring regulation of strip mining. EPA Administrator Russell Train, who had argued against the vetoes, later expressed the view that President Ford was fundamentally bored by environmental issues and that EPA's opposition to the vetoes seemed to be only a minor irritant to him. ${ }^{77}$ While President Ford did not become personally involved in regulatory decisions, friction continued between EPA and the Executive Office during the QOL review process. Administrator Train provided a congressional oversight committee with his own candid assessment of the impact of QOL review on EPA in the waning days of the Ford Administration: "It has certainly made our job more difficult. Whether it has actually resulted in [our making] a decision which we would not otherwise have made or not making a decision which we otherwise would have made, I don't know. I think it simply prolonged the struggle very often."78 Train opined that "there has to be interagency review" and that EPA benefitted from this review. ${ }^{79}$ However, he concluded that EPA "has been singled out for special attention" by OMB, and he urged that EPA, rather than OMB, should control the regulatory review process in the future. ${ }^{80}$

Although Ford was the last president to employ the QOL review process actively, QOL was an important precedent for the regulatory review programs that followed. It also had some beneficial effects on EPA. EPA developed one of the best capacities to analyze regulations of any federal agency ${ }^{81}$ and created an internal clearance process for regulations that increased the administrator's control over the agency's regulatory agenda. ${ }^{82}$

77. John Osborne, White House Watch: The Ford Years xvi (New Republic Books, 1977). Osborne notes that in answer to a question about balancing environmental and economic considerations, Ford once expressed the view that the best way to resolve such problems was to get Russell Train and Federal Energy Administrator Frank Zarb together and "let them work it out." Id at 180 .

78. Status Hearing at 45 (cited in note 25).

79. Id.

80. Id ("I believe that OMB can properly participate in such review sessions, but I don't see $\mathrm{OMB}$ as controlling them, controlling the timetable, holding up, sitting on regulations or proposals."). Train also noted that EPA clearly had not been given sufficient resources to fulfill its broad statutory responsibilities, id at $8,82-83$, and that the agency needed more flexibility in its regulatory authority. Id at 9.

81. Eads \& Fix, Relief or Reform? at 50 (cited in note 26); Susan J. Tolchin \& Martin Tolchin, Dismantling America: The Rush to Deregulate 44 (Houghton Mifflin, 1983). Shortly before leaving office in January 1977, EPA Administrator Russell Train told a Senate committee that the agency's regulatory analyses had improved considerably and that EPA had "about the best economic analytical capability in the Federal Government" at the time. Status Hearing at 10 (cited in note 25).

82. Outgoing EPA Administrator Train reported in January 1977 that EPA had "set up rather stringent procedures for streamlining our regulations by asking not only of every regulation we have already issued, but of every regulation we are thinking of developing: 'Is this regulation really necessary?' These procedures also include a requirement that all regulatory proposals must be approved by my Office before their development." Status Hearing at 70 (cited in note 25). 


\section{The Carter Administration's Regulatory Review Program}

Because President Carter had supported environmental protection measures during his campaign, it was widely anticipated that relations between the Executive Office and EPA would improve dramatically during the Carter Administration. Although the QOL review program was not officially repealed when President Carter took office in January 1977, EPA felt free to ignore it. Acting EPA Administrator John Quarles eventually notified OMB that EPA would no longer participate in QOL reviews. When Douglas Costle took over as EPA administrator in 1977, he indicated that EPA would continue informal interagency consultation and strengthened the agency's Office of Planning and Management, which had been responsible for preparing EPA's regulatory analyses. ${ }^{83}$

To the dismay of many environmentalists, President Carter played a surprisingly active role in efforts to temper EPA regulations. In retrospect, Carter's actions are not as surprising as they may have seemed at the time. In the aftermath of the Watergate scandal, President Carter had campaigned as a Washington outsider who pledged to reform the federal bureaucracy. He promised to reduce the cost of government by reorganizing executive agencies as he had done as governor of Georgia. Thus, it is not surprising that he would support vigorous Executive Office oversight. When the economic consequences of the second OPEC oil price shock led Carter to question whether the economy could afford tighter environmental controls, the Carter White House became more directly involved in regulatory review than any previous administration.

President Carter nominated his friend Thomas B. ("Bert") Lance to be OMB Director. At his confirmation hearings in January 1977, Lance endorsed the notion that $\mathrm{OMB}$ should play a major role in coordinating and reviewing the actions of executive agencies to ensure their consistency with administration policies. ${ }^{84}$ He stated his belief that $\mathrm{OMB}$ should not interfere in agency rulemaking, but he noted that both "the agencies and the Congress would benefit from OMB's role in coordinating-but not 'clearing'-agencies' legislative and regulatory proposals." 85

At the hearings, Democratic Senator Edmund Muskie urged Lance to abandon the QOL review process, arguing that, in the hands of OMB, QOL review had "resulted in compromising agency positions prior to those positions becoming public in order to accommodate special interests." $86 \mathrm{He}$ urged that any OMB oversight occur only after publication of a proposed rule

83. Eads \& Fix, Relief or Reform? at 55 (cited in note 26).

84. Nomination Hearings of Lance and McIntyre at 31 (cited in note 67) (responses to prehearing questions submitted by Sen. Ribicoff) ("With regard to substantive regulations of other agencies, I think it would be appropriate for OMB to review them on a selective basis for consistency with the president's overall policies.").

85. Id at 32. When asked whether OMB should seek to influence a regulatory agency's decision in any rulemaking or adjudicative proceeding pending before the agency, he responded with a flat "No." Id at 35.

86. Id at 84 . 
in order to permit Congress and the public access to the agency's views uncensored by OMB. ${ }^{87}$ Although Lance gave Muskie a noncommittal response, ${ }^{88}$ the regulatory review program subsequently developed by the Carter Administration generally adhered to that advice.

Despite strong opposition to regulatory review from organized labor, President Carter in April 1977 directed agencies to give more detailed consideration to "the economic cost of major government regulations" and requested CWPS to continue to analyze the inflationary implications of regulations. ${ }^{89}$ In August 1977, the Carter Administration circulated to federal agencies a proposal for a new regulatory review process, a process designed to require agencies to perform analyses that focused more on the costeffectiveness of regulations than on cost-benefit analysis. ${ }^{90}$ Under the proposal, a committee of representatives of various federal agencies would select a handful of significant rules for review.91 Citing the bitterness and distrust that the QOL program had engendered in the environmental community, EPA Administrator Costle opposed the concept of formal interagency review. But President Carter ultimately adopted such a program, after decreasing the representation of the "economic agencies" on the review panel and limiting the number of reviews per rule-proposing agency to four each year. ${ }^{92}$

On March 23, 1978, President Carter issued an executive order entitled "Improving Government Regulations," which created the most comprehensive regulatory review program that had ever been established. Declaring that regulations should "not impose unnecessary burdens on the economy," and should be issued only after consideration of meaningful alternatives, Executive Order 12044 required all executive agencies to prepare a "Regulatory Analysis" ("RA") for major regulations. Major regulations were defined as those that may have major economic consequences, such as an annual economic impact of $\$ 100$ million or more or major increases in costs or prices for individual sectors of the country. ${ }^{93}$

Mindful that previous requirements for regulatory analysis often had produced after-the-fact attempts to justify the regulations, ${ }^{94}$ the Carter Administration required agencies to develop RAs early in the decisionmaking process and to make them available for public comment at the time the agency published its proposed rule in the Federal Register. RAs were to include a

87. Id.

88. Id (noting that "it is easier to try to deal with problems at the outset rather than after they get to be problems, and I would like for us to approach that from that viewpoint").

89. Miller, 1 Regulation at 14 (cited in note 66).

90. Cost-effectiveness analysis focuses on determining the least costly means for achieving a given goal. Cost-benefit analysis focuses on balancing the costs and benefits of an action to determine whether it is worth pursuing.

91. Eads \& Fix, Relief or Reform? at 55 (cited in note 26).

92. Id.

93. Exec Order 12044, 3 CFR 152, 154 (1979).

94. Cost Hearings at 15 (cited in note 73) (testimony of Wayne Grandquist, associate director for regulation, OMB). 
rigorous evaluation of alternatives to the proposed regulatory action, the economic consequences of the proposed action and alternative actions, and the agency's rationale for choosing one alternative over the others. Agencies also were required to publish final RAs at the time a final rule was published and to conduct a "sunset-type" review of existing regulations to determine regulations that could be modified or eliminated. OMB was made responsible for ensuring agency compliance. ${ }^{95}$

CWPS and the president's Council of Economic Advisors ("CEA") joined $\mathrm{OMB}$ in conducting regulatory reviews through an interagency group called the Regulatory Analysis Review Group ("RARG"). ${ }^{96}$ Chaired by the chairman of CEA, RARG was composed of representatives of seventeen major executive agencies $^{97}$ and was made responsible for assisting agencies in analyzing the economic consequences of major rules. A four-member executive committee, including representatives of the CEA, OMB, and two rotating members (one from an "economic agency" and one from a "regulatory agency"), were directed to select ten to twenty major regulations each year for intensive review. Economists from CWPS served as staff reviewers for RARG and assisted in the preparation of RARG's formal comments that were submitted to agencies as part of the public rulemaking record. ${ }^{98}$

Unlike the QOL program, the RARG review process was structured to respect the public rulemaking procedures required by the Administrative Procedure Act and the underlying regulatory statutes. Unlike QOL reviewers, RARG reviewers could not attempt to prevent agencies from issuing rulemaking proposals because RARG review occurred only after an agency

95. Exec Order 12044, 3 CFR 152, 155-56 (1979). Although the Carter Administration's Regulatory Analysis requirement was very similar to the Ford Administration's IIS and EIA requirements, Carter Administration officials argued that their program would be more successful. The old IIS-EIA "[t]oo often . . . was seen as ex post justification of a previously chosen alternativea cosmetic add-on, . . . was not taken very seriously by enough senior officials, and was misinterpreted by many [as requiring unrealistic cost/benefit analysis or resistance to any regulation that raised prices]." The new RA requirement was intended to function as a "genuinely useful and used decisionmaking tool as a regulation evolves, and as a clear track record of what factors are being considered .... There is much greater focus on alternatives, . . O" OMB had taken on an oversight role, and "[ $\mathrm{t}]$ he public would be able to use the RA during the comment period to facilitate informed public participation." Cost Hearings at 46 (cited in note 73) (statement of Thomas D. Hopkins, assistant director for government operations and research, Council on Wage and Price Stability).

96. DeMuth, 4 Regulation at 16 (cited in note 6).

97. RARG's membership included representatives from five "economic agencies" (the Council of Economic Advisers, OMB, Commerce, Labor, and Treasury), eight "regulatory agencies" (EPA, Transportation, Agriculture, Energy, HEW, HUD, Interior, and Justice), the Office of Science and Technology Policy, and CWPS. Robert E. Litan \& William D. Nordhaus, Reforming Federal Regulation $69 \mathrm{n} 18$ (Yale U Press, 1983). CEQ and the president's Domestic Policy Staff were to serve as advisers to RARG.

98. Exec Order 12044, 3 CFR 155 (1979). The Carter Administration regulatory review program had been structured to accommodate objections raised by EPA Administrator Douglas Costle, who had argued that it would be dangerous to resuscitate QOL review, which " "was used more to frustrate EPA in the pursuit of its legal responsibilities than to ensure responsible economic analysis." "Eads \& Fix, Relief or Reform? at 56 (cited in note 26), quoting Memorandum from Douglas Costle to President Carter, August 24, 1977. 
had published a proposed regulation in the Federal Register. ${ }^{99}$ RARG's reviews were designed to take place entirely during the public comment period.100 Unlike QOL reviews, which were conducted in secrecy, RARG reviews produced public documents summarizing the reviewers' concerns. ${ }^{101}$ The RARG program was designed to force agencies to take a harder look at regulatory alternatives, while leaving ultimate regulatory decisions to the responsible agencies. In this respect, the program was similar to NEPA, which sought to influence agency decisions by requiring preparation and consideration of environmental impact statements without dictating any substantive results. Yet when a proposed regulation was selected for review by RARG, extraordinary efforts often were made to persuade the agency to change the substance of its decision.

Although the Carter Administration program emphasized the importance of avoiding unnecessarily burdensome regulations, it did not actually require agencies to base regulatory decisions on cost-benefit analyses. Recognizing the difficulties inherent in efforts to assess the costs and benefits of environmental regulations, the program emphasized the use of costeffectiveness analysis to encourage agencies to select the least burdensome means to achieve their goals. ${ }^{102}$ RARG reviews helped stimulate research into improved methods for quantifying the benefits of environmental regulation, though the program imposed largely procedural, and not substantive, constraints on agency decisionmaking. ${ }^{103}$

99. A briefing paper described the procedures used by RARG for choosing which regulations to review:

When an agency publishes a Notice of Proposed Rulemaking ("NPRM") for a major regulation, it sends a summary of the proposal to the Review Group so that any agency with an interest in the economic impact of the proposal is promptly informed of the proceeding. Any member of the Review Group can request that the Executive Committee consider a review of the draft Regulatory Analysis. A decision to conduct a review is made within two weeks after publication of the NPRM. If two or more Executive Committee members are in favor, review will be held and notice to this effect will be submitted to the agency's public record for this regulatory proceeding.

Cost Hearings at 58, 59 (cited in note 73 ).

100. Id at 10 (statement of Wayne Grandquist, associate director for regulation, OMB)

101. The process for conducting RARG reviews has been described in the following terms:

Once the Executive Committee votes to review a Regulatory Analysis, CWPS prepares a draft statement of concerns which it submits to the Review Group for approval. After taking into account any agency suggestions, CWPS then submits the Review Group's statement of concerns to the agency's public record for this proceeding.

About two weeks before the rulemaking record closes, CWPS delivers a draft report that focuses on these concerns of the Review Group, which meets to discuss the report and any needed changes. CWPS has a week to revise this draft, incorporating written and oral comments submitted by Review Group members.

Generally a second Review Group meeting then is held to go over the revised draft. The Review Group decides whether to accept the revised draft. Any dissenting views of the members are either incorporated in the report or attached separately.

CWPS submits the final Review Group report into the rulemaking record on that last day of the public comment period. Id at 59 .

102. See id at 36-37 (statement of EPA Administrator Costle).

103. Christopher DeMuth attributes the lack of substantive standards for regulatory review under the Ford and Carter programs to variations in the standards imposed by the regulatory statutes and 
RARG reviews of EPA regulations were highly controversial. The RARG staff was composed of mission-oriented economists strongly committed to the use of cost-benefit analysis in setting environmental standards. ${ }^{104}$ EPA officials reportedly had little respect for the RARG review process. Former EPA Administrator Douglas Costle has been quoted as saying that "probably three out of every four CWPS comments on our rule making were cribbed right from industry briefs . . p partly because it suited their economic biases about these issues, and their own perception that they were custodians and keepers of the regulatory reform flame." 105

RARG aggressively challenged several regulations, including EPA's national ambient air quality standard ("NAAQS") for ozone and its new source performance standard ("NSPS") for coal-fired power plants. RARG argued that the NAAQS for ozone would cost \$14-19 billion per year, nearly twice EPA's estimates. ${ }^{106}$ After a series of meetings with White House staff over a two-week period in January 1979, EPA Administrator Costle agreed to relax the ozone standard but not by as much as the White House staff had requested. ${ }^{107}$

White House officials became involved in subsequent regulatory decisions, including rules to implement the Surface Mining Control and Reclamation Act and the NSPS for coal-fired power plants. Environmental groups challenged the decisions in court, questioning the president's authority to influence agency decisions in a manner not reflected in the rulemaking record. ${ }^{108}$ When RARG argued that EPA's proposal to implement the best available technology ("BAT") requirements of the Clean Water Act were "prohibitively expensive," EPA officials protested to Congress and the press. Some EPA officials reportedly felt that "continuing White House intervention in the regulatory process [was] compromising their efforts to establish and enforce antipollution laws." 109 Senator Muskie's committee held oversight hearings to investigate these charges. ${ }^{110}$

Faced with criticism from the committee, President Carter pledged that he would not compromise environmental standards for economic gain. He

doubt concerning the political feasibility of imposing more stringent substantive controls on agencies. DeMuth, 4 Regulation at 16-17 (cited in note 6).

104. Susan J. Tolchin, Presidential Power and the Politics of RARG, Regulation 44 (July/Aug 1979).

105. Landy, Roberts \& Thomas, EPA: Asking the Wrong Questions at 68 (cited in note 20).

106. Id.

107. In its notice of proposed rulemaking, EPA had proposed to relax the existing ozone standard of $.08 \mathrm{ppm}$ by raising it to $.10 \mathrm{ppm}$, indicating it might go as high as $.12 \mathrm{ppm}$. Despite pressure from industry and the White House staff to relax it even further, Costle ultimately adopted a $.12 \mathrm{ppm}$ standard. See id at 63.73 .

108. Sierra Club v Costle, 657 F2d 298 (DC Cir 1981).

109. Philip Shabecoff, Some in EPA Assail White House Moves, NY Times Al (Feb 22, 1979) (noting that White House interference "has led several senior officials at the environmental agency to talk of resigning," and that EPA officials complained that RARG's economists invariably represented industry viewpoints: "This often amounts to giving industry one more shot at weakening the regulations after the record is closed," an anonymous EPA official said).

110. Executive Branch Review of Environmental Regulations, Hearings before the Subcommittee on Environmental Pollution of the Senate Committee on Environment and Public Works, 96th Cong, Ist Sess 3 (1979) ("Executive Branch Hearings"). 
endorsed the notion that he had a right to intervene in EPA decisionmaking in the future but pledged that this power would be exercised very sparingly. ${ }^{\prime \prime \prime}$ Although Carter's statement did not entirely end White House efforts to intervene in agency decisions, ${ }^{112}$ it was interpreted as substantially weakening RARG's influence on agency officials. ${ }^{113}$ During the next year RARG published only one analysis of a proposed regulation. ${ }^{114}$

Toward the close of the Carter Administration, the nation's growing economic problems increased interest in measures to reduce the cost of regulation. In 1979, the Joint Economic Committee of Congress recommended that consideration be given to adopting a "regulatory budget" that would limit the total costs a regulatory agency could impose on industry in a given year. In its 1980 annual report, the president's Council of Economic Advisors emphasized the desirability of measures to improve the ability of regulatory agencies to set priorities. ${ }^{115}$

Efforts to reduce the burden of regulation on industry are reflected in two laws enacted in 1980 at the close of the Carter Administration: the Regulatory Flexibility Act and the Paperwork Reduction Act ("PRA")."16 The Regulatory Flexibility Act requires agencies to analyze the impact of their regulations on small businesses. The PRA broadened OMB's prior authority to prevent agencies from collecting unnecessary information ${ }^{117}$ by requiring that OMB review and clear all proposed information collection requests. ${ }^{118}$ While the regulatory review programs previously had been a product of executive orders, the PRA provided a statutory foundation for OMB review of agency action. The act created the Office of Information and Regulatory Affairs ("OIRA") in OMB, which now conducts regulatory reviews for the Executive Office.

\section{The Reagan Administration Regulatory Review Program}

President Reagan arrived in Washington determined to roll back what he perceived to be excessive federal regulation. As one observer explains:

As a long-time opponent of the excesses of government waste, [President Reagan] carried with him a long list of anecdotes about OSHA-designed toilet seats and

111. Philip Shabecoff, Environment Vow Made by President, NY Times A15 (Feb 28, 1979).

112. Two months later Stuart Eizenstat, director of the White House domestic policy staft, reportedly phoned the Office of the Federal Register to block publication of Department of Energy regulations encouraging coal conversions because they had not been reviewed by RARG. Tolchin \& Tolchin, Dismantling America at 46 (cited in note 81 ).

113. DeMuth, 4 Regulation at 20-21 (cited in note 6) (Carter's statement "was interpreted as a clear signal that he wished to leave final regulatory judgments to his regulatory officials themselvesand that his staff regulatory reviewers were to function primarily as kibitzers rather than as superregulators threatening presidential intervention to force compliance with their own policy ideas.").

114. Id at 24 .

115. Christopher C. DeMuth, The Regulatory Budget, 4 Regulation 29, 30 (March/April 1980).

116. Respectively, Pub L No 96-354,94 Stat 1164 (1980), codified at 5 USCA $\S 601$ (1988); Pub L. No 96-511, 94 Stat 2812 (1980), codified at 44 USCA $\S 3501$ (1988).

117. The Federal Reports Act $\S 3(d)$, Pub L No 77-831 (1942) (granting prior authority).

118. 44 USCA $\S 3520$ (c) (1988). Federal paperwork requirements cost private industry, state and local government and individuals between $\$ 30$ and $\$ 40$ billion per year. Commission on Federal Paperwork, Final Summary Report 5 (Oct 3, 1977). 
polluting trees. If there was any doubt about the Republican Party's intentions, it should have been put to rest by the 1980 platform, which stated that "The Republican Party declares war on government overregulation."119

Eads and Fix argue that the Reagan Administration's hostility to federal regulation was motivated by two principal ideas. First, regulatory relief was perceived as a way to stimulate the economy. ${ }^{120}$ Second, President Reagan viewed government regulation as an unwarranted intrusion into private conduct. As a result, while previous regulatory review programs had been motivated by concern for improving the quality of regulations, the Reagan Administration's principal objective was far more radical: to eliminate as much regulation as possible.

On his first working day in office, President Reagan announced the formation of a cabinet-level Task Force on Regulatory Relief chaired by Vice President George Bush. ${ }^{121}$ The Task Force was charged with developing a program to review new regulatory proposals, reassessing existing regulations that were particularly burdensome to industry, and developing legislative proposals "to codify the President's views on the appropriate role and objectives of regulatory agencies." 122 Less than a week after its formation, the Task Force announced it was suspending nearly 200 pending regulations. Vice President Bush sent a letter to corporate executives throughout the country asking them to identify existing regulations that were unduly burdensome. ${ }^{123}$ The Task Force used these responses during the next two years to develop a "hit list" of 119 existing regulations identified as candidates for reconsideration. ${ }^{124}$

On February 17, 1981, President Reagan issued an executive order that established the basic structure of the regulatory review program that remains in effect today. Executive Order 12291 requires executive agencies to submit all proposed rules and final regulations to OMB for prepublication review. ${ }^{125}$ Major rules, defined as rules with an annual effect on the economy of $\$ 100$ million or more, must be accompanied by a detailed cost-benefit analysis, known as a regulatory impact analysis ("RIA"). Agencies must submit RIAs

119. Jeffrey A. Eisenach, A White House Strategy for Deregulation, in Charles L. Heatherly \& Burton Yabe Pines, eds, Mandate for Leadership III: Policy Strategies for the 1990s, 88 (Heritage Foundation, 1989).

120. David Stockman (OMB director), Avoiding a GOP Economic Dunkirk (Dec 1980) (Memorandum) ("A dramatic, substantial rescission of the regulatory burden is needed for the short term cash flow it will provide to business firms and [for] the long term signal it will provide to corporate investment planners."), quoted in Eads \& Fix, Relief or Reform? at 1-2 (cited in note 26).

121. The other members of the Task Force included the Director of OMB, the Secretaries of Treasury, Commerce and Labor, the Attorney General, the Chairman of the Council of Economic Advisors and the Assistant to the President for Policy Development. Role of OMB in Regulation, Hearings before the Subcommittee on Oversight and Investigations of the House Energy \& Commerce Committee, 97th Cong, Ist Sess 43 (1981) ("OMB Hearings").

122. Id at 44 .

123. Id at 415 .

124. NAPA, Presidential Management at 10 (cited in note 72 ).

125. 3 CFR 127 (1982), reprinted as a note in 5 USC $\$ 601$ (1982). OMB's Office of Information and Regulation Affairs ("OIRA") has been delegated the responsibility for conducting regulatory reviews under Exec Order 12291. 
and notices of proposed rulemaking to $\mathrm{OMB}$ at least sixty days prior to publication of major rules. For nonmajor rules, all notices of proposed rulemaking and final rules are to be submitted to OMB at least ten days prior to publication.

The preamble to Executive Order 12291 states the objectives of the Reagan Administration's regulatory review program: "to reduce the burdens of existing and future regulations, increase agency accountability for regulatory actions, provide for presidential oversight of the regulatory process, minimize duplication and conflict of regulations, and insure wellreasoned regulations." 126 To accomplish these objectives, OMB is directed to review regulatory actions based on a set of substantive criteria. ${ }^{127}$

The Reagan program significantly departed from its predecessors in several important respects. First, it centralized power in OMB to an unprecedented degree. Unlike previous programs that authorized review only of selected regulations, the Reagan program required that all proposed and final regulations be submitted to OMB for prepublication review. ${ }^{128}$ Even more significantly, the Reagan program purported to give OMB the authority to block publication of regulations for an indefinite period of time while review was pending. Unlike RARG reviews, which were conducted during the course of public rulemaking proceedings, the Reagan program directed agencies to "refrain from publishing" any rule until OMB had completed its review. ${ }^{129}$

Another significant feature of the Reagan program was that it established substantive criteria for agencies to use in setting regulatory standards. The criteria dictate that agencies should not issue regulations unless their benefits exceed their costs, that agencies should choose regulatory alternatives that involve "the least net cost to society," and that regulatory priorities should be set to maximize "aggregate net benefits to society."130 Unlike Reagan's program, the Carter Administration's regulatory review program had encouraged agencies to develop cost-effective regulations but had repeatedly emphasized that cost-benefit tests were not required. ${ }^{131}$

Finally, the Reagan program was the first to attempt to effect a comprehensive relaxation of existing regulations. Agencies were instructed to suspend or postpone the effective date of rules that already had been promulgated but not yet put into effect. ${ }^{132}$ The majority of the 119 existing

126. Id.

127. Id at $\S 2(\mathrm{~d}),(\mathrm{e})$.

128. See, however, id at $\S 8$ (a) (purporting to exempt regulations that respond to emergency situations and regulations for which review would conflict with statutory or judicial deadlines); $\$ 8(\mathrm{~b})$ (authorizing $\mathrm{OMB}$ to exempt certain types of regulations).

129. Id at $\S 3(\mathrm{f})$.

130. Id at $\S 2$. This directive is qualified by the phrase "to the extent permitted by law."

131. Eads, White House Oversight at 180-81 (cited in note 68).

132. This resulted in the suspension of 172 regulations. Eads \& Fix, Relief or Reform? at 121 (cited in note 26 ). 
regulations on the "hit list" of regulations designated for reconsideration were environmental or health and safety regulations. ${ }^{133}$

Even more significant than the structure of the review program was the type of people President Reagan appointed as agency officials responsible for implementing the "regulatory relief' campaign. By appointing persons philosophically hostile toward regulation, the President ensured that his goal of "regulatory relief" would be zealously pursued.134 It soon became apparent that the new regulatory review process was well-designed to facilitate this goal because it gave OMB unprecedented power over agency decisionmaking.

While the executive order purported to leave ultimate decisionmaking responsibility with the agencies, ${ }^{135}$ as a practical matter it gave OMB enormous power to influence the substance of regulatory decisions. "The Government works using three things: money, people, and regulations; the agency must get all three through OMB."136 The source of OMB's power under Executive Order 12291 is the ability to invoke the "extended review" provisions contained in section 3(f). Because Executive Order 12291 directs agencies to "refrain from publishing" rules until OMB's review is concluded, OMB can block regulations it finds objectionable for an indefinite period of time.

Despite the vigorous denials of its officials, OMB has acquired virtual veto power over regulations it reviews. ${ }^{137}$ As a former OIRA administrator said, "[i]f you're the toughest kid on the block, most kids won't pick a fight with you."138 In August 1983, OMB officials could not cite a single instance in which a rule disapproved by $\mathrm{OMB}$ had been promulgated by the agency. ${ }^{139}$ Three years later OMB was able to cite only six instances in which proposed or final rules had been promulgated over its objections. In four of them, the agency acted under the compulsion of a judicial deadline. In the other two, the agency had successfully appealed to the White House. ${ }^{140}$ Former EPA

133. Id at 118-20. Presidential Task Force on Regulatory Relief, [Year End Summary of the Administration's Regulatory Relief Program] (Dec 30, 1981) (reporting that 54 of 91 existing regulations designated for reconsideration during 1981 were environmental or health and safety regulations) (copy on file with author).

134. See Roland Evans \& Robert Novak, The Reagan Revolution 143-48 (Dutton, 1981).

135. Exec Order $12291, \S 3(\mathrm{f})(3), 3$ CFR 127 (1982) (specifying that the order is not to be "construed as displacing the agencies' responsibilities delegated by law").

136. Erik D. Olson, The Quiet Shift of Power: Office of Management and Budget Supervision of Environmental Protection Agency Rulemaking under Executive Order 12291, 4 Va J Nat Res L 1, 6 (1984), quoting Jim Tozzi, former OIRA Deputy Administrator.

137. Id at 43-46 n209.

138. Antonin Scalia, Deregulation HQ: An Interview on the New Executive Order with Murray $L$. Weidenbaum and James C. Miller III, 5 Regulation 22 (March/April, 1981) (quoting former OIRA Administrator Miller).

139. Olson, 4 Va J Nat Res $L$ at 44 (cited in note 136).

140. Response of OMB Director James C. Miller, III, to written questions from Senator Frank R. Lautenberg (Feb 19, 1986), attached to letter from Senator Mark O. Hatfield to Senator Frank R. Lautenberg (March 14, 1986) (on file with author) (citing four rules subject to court-ordered deadlines: OSHA's ethylene oxide standard, EPA's fluoride drinking water standards, EPA's regulations for heavy duty truck emissions of NOx and particulate matter, and HUD's lead paint 
Chief of Staff John Daniel has testified that when EPA promulgated a regulation required by court order without obtaining OMB approval, he received a late night phone call from an OMB official informing him that "there was a price to pay for doing what we had done, and that we hadn't begun to pay." 141

Like the QOL review process, the Reagan program sought to shield regulatory reviews from public view. By directing OMB to conduct its review prior to publication of proposed regulations, the executive order deprived the public of an opportunity to learn the unfiltered views of the agency. ${ }^{142}$ Unlike the RARG program, which produced public reviews, under the Reagan program documents reflecting OMB's reviews were not incorporated into the public record, even in rulemakings under the Clean Air Act where Congress had explicitly required it. ${ }^{143}$

In the early days of the Reagan program, congressional oversight hearings lent credence to charges that OMB had served as a vehicle for secret, back door lobbying by industry. John Daniel testified that he discovered that OMB had leaked draft EPA rulemaking proposals to industry when an industry representative mistakenly called EPA, rather than OMB, to provide his comments. ${ }^{144}$ In response to such charges, $\mathrm{OMB}$ initially established policies requiring $O M B$ staff to advise the public to submit factual materials to the relevant agency rulemaking docket and prohibiting low-level staff from meeting with industry. ${ }^{145}$ A comprehensive study of the early years of the Reagan program found that these policies often were honored in the breach. ${ }^{146}$

The Reagan Administration's regulatory review program was, at the least, highly controversial. Former EPA Administrator Anne Gorsuch Burford, originally an enthusiastic promoter of the program, later testified that while presidential oversight of rulemaking is appropriate, "there were some serious abuses" by OMB. ${ }^{147}$ The Reagan Administration's single-minded emphasis

standards; and two rules where the president or the Task Force on Regulatory Relief were consulted: Interior's oil and gas lease lottery regulations and OSHA's cotton dust standard).

141. EPA: Investigation of Superfund and Agency Abuses (Part 3), Hearings before the Subcommittee on Oversight and Investigations of the House Energy \& Commerce Commission, 98th Cong, 1st Sess 7-8 (1983) ("EPA Investigation Hearings").

142. Eads \& Fix, Relief or Reform? at 111 (cited in note 26).

143. Section 307(d)(4)(B)(ii) of the Clean Air Act, 42 USC \& 7607(d)(4)(B)(ii) (1988), requires that drafts of EPA's proposed and final rules submitted to OMB for review, all written comments by $\mathrm{OMB}$ or other agencies, and all written responses to comments be placed in the public docket of rulemakings under the act. Erik Olson's study found that compliance with this requirement is rare. Olson, 4 Va J Nat Res L at $71 \mathrm{nn}$ 367-70 (cited in note 136).

144. EPA Investigation Hearings at 80 (cited in note 141).

145. Memorandum from David Stockman to Heads of Executive Departments and Agencies, Certain Communications Pursuant to Executive Order 12291 (June 11,1981 ), reprinted in OMB, Regulatory Program of the United States Government April 1, 1990-March 31, 1991 at 618 (1990)

("Stockman Memorandum").

146. Olson, $4 \mathrm{Va} J \mathrm{Nat}$ Res $\mathrm{L}$ at 62-64 (cited in note 136).

147. EPA Investigation Hearings at 234 (cited in note 141). 
on regulatory relief is now widely viewed as a critical mistake that forfeited a rare opportunity for achieving truly beneficial regulatory reform. ${ }^{148}$

Critics of the Reagan program charge that it illegally delayed EPA promulgation of regulations, displaced EPA decisionmaking authority, subverted statutory standards, and excluded the public from full participation in the regulatory process. ${ }^{149}$ These and other criticisms contributed to the atmosphere of scandal that surrounded EPA, culminating in the mass resignation of agency officials, including Administrator Burford, in 1983. Burford was replaced by former EPA Administrator William Ruckelshaus.

In response to questions submitted during the confirmation hearings for his return to EPA, Ruckelshaus emphasized that OMB would not interfere with his ultimate decisionmaking authority. ${ }^{150}$ While Ruckelshaus is generally credited with restoring some measure of public confidence in EPA, he did not succeed in insulating EPA from OMB's substantial influence. ${ }^{151}$ For example, Ruckelshaus's plan to propose a modest acid rain control program was vetoed after OMB Director David Stockman ridiculed it by arguing that it would cost several thousand dollars per pound of fish saved. ${ }^{152}$

While continuing opposition to new regulatory initiatives, the Reagan Administration gradually abandoned its ambitious plans for regulatory relief. On August 11, 1983, the Task Force announced that it was disbanding, claiming that its actions would save business, government, and consumers more than $\$ 150$ billion over ten years. Although the Task Force announced that the Reagan Administration would now concentrate on changing the regulatory statutes, the administration subsequently failed to pursue significant changes in the environmental laws. ${ }^{153}$ Later that year, an omnibus regulatory reform bill that would have codified regulatory review procedures passed the Senate but died in the House. ${ }^{154}$ This ended the administration's hopes for legislation endorsing its regulatory relief objectives.

Subsequent environmental legislation imposed increasingly stringent regulatory standards, while tightly constraining EPA's discretion by imposing a multitude of deadlines and adopting "hammer" provisions that specified the

148. Robert W. Crandall \& Paul R. Portney, Environmental Policy, in Paul R. Portney, ed, Natural Resources and the Environment: The Reagan Approach 56-77 (Urban Inst Press, 1984); Eads \& Fix, Relief or Reform? (cited in note 26); Susan Rose-Ackerman, Defending the State: A Skeptical Look at "Regulatory Reform "in the Eighties, 61 U Colo L. Rev 517, 524-26 (1990).

149. These charges are extensively documented in Olson, 4 Va J Nat Res $\mathrm{L} l$ (cited in note 136). A popular critical account of the EPA scandals and the Reagan Administration's regulatory relief effort is contained in Jonathan Lash, et al, A Season of Spoils: The Reagan Administration's Attack on the Environment (Pantheon Books, 1984).

150. Olson, $4 \mathrm{Va} \mathrm{J}$ Nat Res $\mathrm{L}$ at $45 \mathrm{n} 218$ (cited in note 136) (response to written questions from Senator Stafford following confirmation hearings).

151. Critics of OMB review, manv of whom have considerable respect for Ruckelshaus, concluded that OMB interference with EPA continued even after his return. See, for example, Lash, et al, A Season of Spoils at 322 (cited in note 149).

152. Lash, $A$ Season of Spoils at 322 (cited in note 149).

153. Id at 5-6.

154. S 1080, The Regulatory Reform Act, 97th Cong, 2d Sess 1 (1981), in 127 Cong Rec 29,192 (Nov 30,1981 ). 
precise consequences if EPA failed to meet the deadlines. ${ }^{155}$ Despite these constraints, EPA occasionally proceeded with a new regulatory initiative. For instance, Ruckelshaus won an important victory in March 1985 when EPA promulgated regulations that drastically slashed allowable levels of lead additives in gasoline. ${ }^{156} \mathrm{~A}$ cost-benefit analysis performed by EPA staff played a key role in convincing OMB to clear the regulation because it showed that the regulation would generate more than a billion dollars of net benefits annually. ${ }^{157}$ Ironically, in 1982 the Presidential Task Force on Regulatory Relief had required EPA Administrator Burford to propose the repeal of the very lead limits that Ruckelshaus strengthened. ${ }^{158}$

At the start of President Reagan's second term in office, a new executive order was issued that expanded OMB's regulatory review responsibilities. OMB officials had complained that they often did not become aware of planned rulemaking actions until the eleventh hour when statutory deadlines often compelled agencies to act quickly. To respond to this problem, Executive Order 12498, issued on January 4, 1985, established a regulatory planning process that authorized OMB review up to a year in advance of the initiation of agency action. ${ }^{159}$ The order requires executive agencies to submit annually to OMB a "draft regulatory program" that describes all "significant regulatory actions" the agency intends to undertake during the next year. ${ }^{160}$ If $\mathrm{OMB}$ determines that an agency's regulatory program is consistent "with the Administration's policies and priorities," it is incorporated into an annual document entitled "The Regulatory Program of the United States Government."161

Clashes between EPA and OMB continued even after Ruckelshaus stepped down as EPA administrator. Lee Thomas, who served as EPA administrator during President Reagan's second term in office, had several celebrated battles with $O M B$, including one clash over OMB's vigorous efforts to derail a proposed rule banning most remaining commercial uses of asbestos. EPA announced on February 1, 1985, that it would accede to OMB's demands that the matter be referred to OSHA. However, harsh criticism from a

155. See, for example, Hazardous and Solid Waste Amendments of 1984. Pub L No 98-616, 98 Stat 3221 , codified at 42 USC $\$ \S 6401$ et seq (1988).

156. 40 CFR 80 (1985).

157. Costs and Benefits of Reducing Lead in Gasoline (EPA, 1984).

158. See Eliot Marshall, EP. May Allow More Lead in Gasoline, 215 Science 1375 (March 1982).

159. Exec Order 12498, 3 CFR 323 (1985).

160. Id at 324. "Significant regulatory actions" subsequently have been defined by OMB to include even actions taken to consider whether or not to initiate a rulemaking and actions to develop guidelines, policy proposals, or similar documents that may influence rulemaking at a later date. OMB Bulletin 86-4, at 3 (Dec 23, 1985).

161. $3 \mathrm{CFR}$ at 326. The regulatory program has been described as "a regulatory budget without numbers." Michael Fix \& George Eads, The Prospects for Regulatory Reform: The Legacy of Reagan's First Term, 2 Yale J Reg 293. 312 (1985). 
congressional oversight committee and protests by EPA staff convinced EPA to reverse the decision and to proceed with the proposed rule. ${ }^{162}$

In the early days of the Reagan Administration, public interest groups generally sought to avoid direct legal challenges to OMB's review authority. ${ }^{163}$ During the administration's second term, however, the groups filed lawsuits directly challenging the legality of OMB's actions. ${ }^{164}$ Congress passed an even more serious threat to OMB's review authority when the Democratic leadership threatened to stop funding OIRA's regulatory reviews. This proposed action induced $\mathrm{OMB}$ to announce a new disclosure policy in 1986 that required OMB to make available drafts of regulations sent to OMB for review. ${ }^{165}$

\section{E. Regulatory Review in the Bush Administration}

The Reagan Administration's regulatory review program continues under the Bush Administration, which has not disturbed Executive Orders 12291 and 12498. Although the Bush Administration has not pursued an avowedly deregulatory agenda, controversy between EPA and OMB continues, generating familiar criticism from Congress. OMB's reviews have been a prominent focus of the congressional debate over reauthorization of the Paperwork Reduction Act. ${ }^{166}$ Congressional leaders reportedly reached an agreement with White House officials to reauthorize the act in exchange for the enactment of new limits on OMB reviews. These limits included a time limit on OMB review and a requirement that OMB disclose the positions it had taken during the review. Implementation of this agreement was blocked when unidentified Republican senators placed a last minute hold on the

162. See EPA's Asbestos Regulations, Report on a Case Study on OMB Interference in Agency Rulemaking, Hearings before the Subcommittee on Oversight \& Investigations of the House Energy \& Commerce Committee, HR Rep No 99-2, 99th Cong, lst Sess 1 (1985) (“Asbestos Hearings").

163. A few courts had held that regulatory review under Executive Order 12291 did not excuse agencies from meeting their statutory obligations. Center for Science in the Public Interest $v$ Dep't of the Treasury, 573 F Supp 1168, 1175 (D DC 1983), reversed on other grounds, 797 F2d 995 (DC Cir 1986) ("the broad thrust of [12291] provides an insufficient basis for the defendants to disregard their statutory duties"); NRDC v Corsuch, Nos 2153 et al (D DC Aug 25, 1982); NRDC v Ruckelshaus, 14 ELR 20817, 20819 (D DC Sept 14, 1984) (OMB review no justification for extending time for compliance with statutory deadlines).

164. See, for example, Dole v United Steelworkers of America, $110 \mathrm{~S} \mathrm{Ct} 929$ (1990) (OMB has no authority under the Paperwork Reduction Act to block OSHA regulations mandating disclosure of hazards); Wolfe $v$ Dep 't of Health and Human Services, 839 F2d 768 (DC Cir 1988) (en banc) (information about whether or not a proposal for regulation has been sent to OMB for review is exempt from disclosure under the Freedom of Information Act); Public Citizen Health Research Group $v$ Tyson, 796 F2d 1479 (DC Cir 1986) (OSHA's deletion of short-term exposure limit from regulation limiting workplace exposures to ethylene oxide, which was undertaken at OMB's behest, was unsupported by the record); Environmental Defense Fund v Thomas, 627 F Supp 566 (D DC 1986) (OMB has no authority to block EPA promulgation of regulation once a statutory deadline has expired).

165. See Robert V. Percival, Rediscovering the Limits of the Regulatory Review Authority of the Office of Managememl and Budget, 17 Envir L Rev 10017 , 10023 (1987)

166. See, for example, Reauthorization of the Paperwork Reduction Act, Hearings before the Subcommittee on Govt Information and Regulation of the Senate Committee on Governmental Affairs, 10lst Cong, Ist Sess 1 (1989). 
reauthorization bill. ${ }^{167}$ As a result, the Paperwork Reduction Act has not been reauthorized and the Senate Governmental Affairs Committee has refused to confirm the Bush's nomination of a new OIRA administrator. ${ }^{168}$

The most significant change made by the Bush Administration in the regulatory review program has been the creation in 1989 of an interagency task force known as the Council on Competitiveness. Chaired by Vice President Quayle, the council is designed to serve as the successor to the Reagan Administration's Task Force on Regulatory Relief. ${ }^{169}$ In this capacity, the council's responsibilities include coordinating administration regulatory policy and hearing appeals of disputes between OIRA and agencies that arise in the course of regulatory reviews.

Council members' agency ties make it unlikely the council will be sympathetic to environmental regulation. The council's six permanent members are the director of OMB, the Secretary of Commerce, the Secretary of the Treasury, the chairman of the President's Council of Economic Advisers, the White House Chief of Staff, and the Attorney General. In its first major regulatory decision, the council upheld OIRA's disapproval of a new source performance standard for municipal incinerators that required recycling of 25 percent of the waste streams. ${ }^{170}$ This rejection of a major regulatory initiative, one that EPA had spent years developing and that previously had been cleared by $\mathrm{OMB}$, has been interpreted as presaging a resurgence of the kind of anti-regulatory fervor that prevailed in the early days of the Reagan Administration. While it is still too early to tell how frequently the council will be asked to intervene in disputes between EPA and OIRA, ${ }^{171}$ the council's composition and its veto of the recycling requirement will undoubtedly increase EPA's hesitancy to appeal an OIRA veto. The existence of the council is likely to strengthen OIRA's hand in disputes with EPA, making questions concerning the desirability and appropriate scope of regulatory review even more important.

167. The White House reportedly agreed to accept new restrictions on OMB review only after the chairman of the House Government Operations Committee threatened to "defund" OIRA. See Defying Bush, GOP Senators Block Deal to Curb OMB Power over EPA Rules, Inside EPA 1, 7 (Nov 16, 1990). The hold on the reauthorization bill reportedly was placed by Republican Senators who are seeking an amendment that would overturn the Supreme Court's decision in Dole v United Steelworkers of America, 110 S Ct 929 (1990), which held that the Paperwork Reduction Act did not give OMB authority to review regulations requiring companies to disclose information to private individuals.

168. Inside EPA at 7 (cited in note 167)

169. OMB, Regulatory Program at 5 (cited in note 145) (President Bush confirmed that "[i]n reviewing regulatory matters, the Council will be continuing the work of the former President's Task Force on Regulatory Relief .....").

170. Michael Weisskopf, EPA Proposal on Recycling Is Trashed, Washington Post Al7 (Dec 20, $1990)$.

171. Encouraged by the veto of the recycling rule, opponents of EPA regulation are now pressing the Competitiveness Council to review additional EPA regulations. See, for example, EPA Siaff Wom First Visibility Call May Go Before Competitiveness Council, Inside EPA 1 (Jan 25, 1991 ). 


\section{III}

\section{The Impact of Executive Office Oversight on EPA}

The impact of Executive Office oversight has been a controversial subject, but this controversy is not due to a lack of data. OMB's annual reports provide considerable statistical data on the regulatory review process during the Reagan and Bush programs, though such data obviously cannot capture the full impact of regulatory review. The voluminous literature includes a few careful studies of the impact of Executive Office oversight on agency decisionmaking. ${ }^{172}$ Accounts provided by former participants in the process also facilitate analysis of its effects. Three principal concerns about the impact of regulatory review on EPA warrant further exploration: (1) that it has delayed EPA rulemaking; (2) that it has usurped EPA's decisionmaking authority and produced weaker environmental regulations; and (3) that it has reduced the public's ability to monitor the rulemaking process and influence regulatory decisions. ${ }^{173}$

\section{A. The Speed of the Rulemaking Process}

The most widely recognized impact of regulatory review has been significant delays in agency rulemaking. The Nixon Administration's QOL review was often criticized for delaying EPA's issuance of regulations. ${ }^{174}$ During the Ford Administration, EPA officials identified "lengthy delays" as the worst problem generated by QOL review. ${ }^{175}$ An EPA study estimated that QOL review added nearly two months to the time required to issue a typical regulation. ${ }^{176}$

The Carter Administration's regulatory review program was designed to avoid delay in rulemaking by conducting review during the normal course of the public comment period. While it was not always successful in avoiding delays, ${ }^{177}$ the program was rarely criticized on this ground because the delays it generated were not as egregious as those caused by QOL review. By

172. These include NAPA, Presidential Management (cited in note 72): Eads \& Fix, Relief or Reform? (cited in note 26) (focusing on the impact of the Reagan Administration's initial regulatory relief program); and Olson, $4 \mathrm{Va} \mathrm{J}$ Nat Res $\mathrm{L} l$ (cited in note 136) (focusing on the impact of the Reagan regulatory review program on EPA).

173. See, for example, Alan B. Morrison, OMB Interference with Agency Rulemaking: The Wrong Way to Write a Regulation, 99 Harv L Rev 1059, 1064 (1986).

174. Executive Branch Hearings at 3 (cited in note 110) (John Quarles testifying that QOL review "added substantial delay to an already lengthy process.").

175. 7 Envir Rptr (BNA) 693 (cited in note 33).

176. Id at 694. The study found that EPA's own internal process had contributed to delays. Of the median time of more than three months between sending regulations out for QOL review and sending them to the Federal Register, " 56 days is for OMB review after the regulation was initially sent to the agencies, and the remaining 54 days is spent on final review prior to signature of the EPA administrator." Id (recommending that EPA shorten the long delay between OMB review and final approval by assuming other EPA officials do not object to proposed regulations if they are not heard from within two weeks of receiving a proposal).

177. For example, although RARG's efforts to force OSHA to promulgate a weaker permissible exposure limit for cotton dust in the workplace in 1978 were largely unsuccessful after Labor Secretary Ray Marshall appealed in person to President Carter, RARG review prevented OSHA from meeting a court-ordered deadline. Eads \& Fix, Relief or Reform? at 58 (cited in note 26). 
contrast, the Reagan Administration's program encountered harsh criticism for causing delay. ${ }^{178}$ A study of the program by the National Academy of Public Administration ("NAPA") found that the "clearest impact of the regulatory management process has apparently been in slowing down rulemaking activities." 179

An important distinction can be made between programs requiring prepublication clearance (such as the QOL and Reagan review programs) and the Carter program that did not. By adding another step to the rulemaking process, programs that require prepublication clearance inevitably lengthen the time it takes for EPA to promulgate regulations. By requiring prepublication clearance for both proposed and final regulations, the Reagan/Bush program compounds this problem. ${ }^{180}$

Table 1 provides data on the average length of OMB review for EPA regulations. The data indicate that the average OMB review now takes substantially more time than the ten-day and sixty-day periods contemplated in Executive Order 12291. The data also indicate that OMB takes considerably longer to review EPA regulations than those of other agencies.

\section{TABLE 1}

Average Review Time (Days) of EPA Rules

Under Executive Order 12291

$\begin{array}{lccr}\text { Year } & \text { Major } & \text { Non-Major } & \text { All } \\ 1981 & 12 & 9 & 9 \\ 1982 & 88 & 17 & 19 \\ 1983 & 14 & 22 & 22 \\ 1984 & 58 & 30 & 31 \\ 1985 & 78 & 33 & 35 \\ 1986 & 41 & 41 & 41 \\ 1987 & 49 & 35 & 37 \\ 1988 & 51 & 48 & 49 \\ 1989 & 104 & 49 & 52 \\ 1981-1989 & 64 & 26 & 28 \\ \text { All Govt } & 40 & 21 & 21\end{array}$

Source: OMB, Regulatory Program of the United States Government April 1, 1990-March 31, $1991,647(1990)$.

When it established its regulatory review program, the Reagan Administration acknowledged that the program would slow down the rulemaking process but defended such delays as "necessary-and well worth

178. See, for example, Douglas M. Costle, Environmental Regulation and Regulatory Reform, 57 Wash L Rev 409, 409-10 (1982).

179. NAPA, Presidential Management at 7 (cited in note 72 ).

180. See Scalia, 5 Regulation at 17 (cited in note 138) ("What all that adds up to is that-making very conservative assumptions with respect to time periods . . . it will ordinarily take an agency at least seven months (210 days) to get a rule into effect-that's 90 days longer than under the previous system."). 
it-to make sure that new rules do more good than harm."181 Much of the delay under the Reagan program can be attributed to OMB's propensity to extend review for regulations it deems objectionable. By March 1984, these delays had become so egregious that EPA began compiling statistics to demonstrate their impact. These statistics showed that average extension time per rule fluctuated between fifty and one hundred days in 1984 and 1985.182 Based on this data, the Senate Committee on Environment and Public Works reported that for rules in which review was extended "OMB holds minor rules for an average of over two months and major rules for over four months." 183

EPA's new source performance standards ("NSPS") have been a particular victim of OMB delay, apparently because of OMB's opposition to technologybased standards. A December 6, 1985 EPA memorandum revealed that OMB had been reviewing arsenic standards since February 19, 1985, despite a January 7, 1984 statutory deadline; NSPSs for sewage treatment plants since March 19, 1985, despite a November 27, 1983 statutory deadline; and NSPS for volatile liquid storage since August 19, 1985, despite an August 7, 1982 statutory deadline. ${ }^{184}$

OMB officials argue that the agencies cause much of the delay by failing to respond to questions raised by OMB. ${ }^{185}$ Sensitive to accusations of politically motivated delay, OMB in 1989 instituted a policy of "suspending" review of a rule when it believes that the promulgating agency has not responded in a timely fashion to OMB requests for additional information. ${ }^{186}$ This policy should allow $O M B$ to report a decline in average length of time taken for its regulatory reviews, because OMB will no longer consider "suspended" rules in its calculations. In 1989, the first year this policy was in effect, OMB suspended review of four EPA regulations, ${ }^{187}$ yet the average length of time OMB took to review EPA rules set an all-time high, as indicated in Table 1.

181. Id at 17.

182. Memorandum, Office of Policy, Planning and Evaluation, OMB Extended Reviews for the Week of December 6, 1985 (on file with author) ("OPPE Memorandum").

183. OMB Influence on Agency Regulations, Senate Committee on Environment and Public Works, 99th Cong, 2d Sess 9 (1986).

184. OPPE Memorandum (cited in note 182).

185. Demystifying Environmental Policy Review at OMB: A Forum Interview with OIRA Administrator $S$. Jay Plager, 6 Envir Forum 27, 30 (July/Aug 1989), quoting Plager as complaining that "[i]f an agency wants to game us, what they will do is when we ask them a bunch of questions about a rule they've sent over, they'll just not answer."; NAPA, Presidential Management at 37 (cited in note 72), quoting former OIRA Deputy Director Robert Bedell as conceding that " $[0] n$ the delays, much is our mistake because we did not drive to get them done," but noting that "[m]ore are a result of the agency not giving us the information we need."

186. Exec Order 12291, Annual Report for 1989, reprinted in OMB, Regulatory Program at 634 (cited in note 145).

187. The EPA rules whose review OMB suspended included four hazardous waste regulationsincluding EPA's standards for performing corrective action at hazardous waste management facilities, a centerpiece of the new regulations required by Congress in the 1984 Amendments to RCRA designed to prevent the proliferation of Superfund sites in the future. This regulation was not cleared until nearly two years after OMB had received it, long after the statutory deadline for promulgating the regulation had expired. Id at 646. 
EPA's perspective on why regulatory review contributes to delay is somewhat different from OMB's.

The problem is not one of failure in resolving issues that are brought up to OMB. The problem is that $\mathrm{OMB}$ has no incentive whatsoever to keep the process moving and no one to which they are accountable for failures of responsiveness.

At the present time, OMB can unilaterally extend the comment period on EPA packages. ... When an extension is requested, the time period is indefinite and lasts until OMB is ready to respond. This can be more than a year. Once a dialogue has begun, OMB tends to repeatedly find new issues each time the last issue is settled, often with long intervening delays. Often, as was the case in the beverage can NSPS these issues involve questioning the technical judgment of EPA rather than the implications of costs, benefits, and impacts to society. ${ }^{188}$

The charge against the QOL process that "OMB sometimes use[d] delay as an intentional strategy" to influence the substance of regulations ${ }^{189}$ has also been frequently directed toward the Reagan/Bush program. After a certain point, continued delay tends to confirm that OMB is simply using delay to block regulation until EPA adopts OMB's views. Although they previously had denied that they used delay as a strategic tool, OMB officials implicitly confirmed that charge when they announced in 1989 that they would pursue a "new direction" that would not use delay to block rules. OMB Director Richard Darman reportedly instructed OMB staff that, rather than delaying rules indefinitely, they are to negotiate directly with agency staff in cases where "genuine disagreement exists."'190

Except in cases of extended OMB reviews, Executive Office oversight is not the principal reason why the rulemaking process takes so long. Other procedural requirements ${ }^{191}$ and incentives that encourage strategic behavior $^{192}$ have contributed to the glacial pace of the process. ${ }^{193}$ A great deal of the blame lies with the agencies themselves; some lies with the courts. ${ }^{194}$

188. New Source Performance Standards: Beverage Can Industry-A Case Study (Emissions Standards and Engineering Division, Office of Air Quality Planning and Standards, Office of Air, Noise and Radiation, EPA, Aug 23, 1983), quoted in OMB Influence on Agency Regulations at xvi (cited in note 183).

189. Id at 695 , citing delays in responding to the markup of what became $\$ 404$ of the Clean Water Act and noting that OMB prohibited EPA from transmitting to Congress proposed legislation when Congress considered what became the Toxic Substances Control Act.

190. OMB Official Promises End to Rule Delays, But RCRA Rule Still at Agency After Seven Months, Envir Rptr (BNA) 8 (May 5, 1989).

191. But see William F. Pederson, Jr., Formal Records and Informal Rulemaking, 85 Yale L J 38, 55 n73 (1975)(noting that the QOL "review process causes far longer delays in rulemaking than anything the Administrative Procedure Act standing alone requires").

192. Groups opposed to development frequently have benefitted from delays engendered by NEPA's requirement that environmental impact statements ("EISs") be prepared before federal agencies take actions that have a significant impact on the environment. See Environmental Quality1983, at 265 (Council on Environmental Quality, 1983) (reporting that nearly half the injunctions obtained in 277 NEPA lawsuits delayed projects by more than one year). For most environmental regulations, delay benefits the regulated community by postponing the need to incur costs to comply with the regulation.

193. Cass R. Sunstein, Paradoxes of the Regulatory State, 57 U Chi L Rev 407, 415 (1990).

194. Judicial review can create substantial delays in the promulgation of regulations, often with little corresponding gain in their quality. For example, by striking down OSHA regulations establishing permissible exposure limits ("PELs") for asbestos and benzene, the Fifth Circuit and the 
As a result of widespread concern over the slow pace of EPA's implementation of its regulatory responsibilities, Congress has imposed numerous statutory deadlines. While section $8(\mathrm{a})(2)$ of Executive Order 12291 purports to exempt from OMB review regulations that must be issued to meet statutory deadlines, OMB often has blocked EPA action despite the expiration of such deadlines. In 1984, a federal district court found that

EPA submitted 169 regulations to OMB which were subject to statutory or judicial deadlines, and on 86 occasions OMB extended its review beyond the time periods outlined in Executive Order 12291. OMB's propensity to extend review has become so great that EPA keeps a running record of the number of its rulemaking actions under extended review by $O M B$ and the resulting delays. The average delay per regulation is 91 days; total delays were more than 331 weeks. Apparently Section 8(a)(2) of Executive Order 12291 is simply ignored. ${ }^{195}$

While the court held that OMB has no authority to delay EPA's promulgation of regulations after a statutory deadline has expired, the decision has not stopped OMB from reviewing such regulations. For example, EPA was required by statute to promulgate revisions to the National Contingency Plan governing Superfund cleanups by April 17, 1988, but OMB objections delayed EPA's publication of proposed revisions until December 1988. ${ }^{196}$ Apparently fearful of further litigation, OMB now rapidly clears such regulations when threatened with a lawsuit. ${ }^{197}$

Statutory or judicial deadlines can impose some additional constraints on the length of OMB review. Indeed, Congress nearly enacted a requirement to limit the length of time OMB could take to complete its regulatory reviews to sixty days with a one-time thirty-day extension upon request of OMB. ${ }^{198}$ In circumstances where OMB review continues after a statutory or judicial

Supreme Court effectively delayed for several years the eventual promulgation of standards at least as stringent as the ones invalidated. See Asbestos Information Assn/North America v OSHA, 727 F2d 415 (5th Cir 1984) (invalidating asbestos PEL of 0.5 fibers per cubic centimeter; in 1986 OSHA promulgated a new PEL of $0.2 \mathrm{f} / \mathrm{cc}$ ); Industrial Union Dep't, AFL-CIO v American Petroleum Institute, 448 US 607 (1980) (striking down OSHA's May 21, 1977 attempt to lower the PEL for benzene from 10 Ppm to 1 ppm; OSHA finally promulgated the new PEL at the same 1 ppm level in 1987, after concluding that workers exposed to benzene of $10 \mathrm{ppm}$ had been experiencing additional risks of death from leukemia of 95 per 1000).

195. EDF $v$ Thomas, $627 \mathrm{~F}$ Supp at 565-71.

196. The Superfund National Contingency Plan: Report on a Case Study of OMB Involvement in Agency Rulemaking, Subcommittee on Oversight and Investigations, House Committee on Energy and Commerce, 101 st Cong, 1st Sess 8-9 (1989).

197. For example, during the first five years of the regulatory review program, OMB had entirely ignored the provisions of Executive Order 12291 that exempt regulations for which review would conflict with a statutory deadline. After a federal district court ruled that OMB had no authority to delay promulgation of such regulations, OMB has rapidly cleared some subsequent regulatory packages when deadline suits were brought. See, for example, OMB Approves RCRA Rule, Staving Off Possible Challenge to its Review Power, Inside EPA 16 (Feb 23, 1990); Environmental Defense Fund v Reilly, No 89-598 (D DC OCt 12, 1990). This may account for the fact that $12 \%$ of all EPA regulations released in 1989 were exempted from OMB review because of statutory or judicial deadlines. Exec Order 12291, Annual Report for 1989, reprinted in OMB, Regulatory Program at 636 (cited in note 145).

198. S 1044, The Federal Information Resources Management Act of 1991. 102d Cong, 1st Sess 1 (May 14, 1991), in 137 Cong Rec S5967-01 (May 15, 1991). 
deadline has expired, judicial intervention is possible, ${ }^{199}$ but in the absence of a fundamental change in the structure of the current review program, regulatory delay is likely to remain a principal impact of regulatory review.

\section{B. The Impact of OMB Review on EPA Decisionmaking}

One of the most significant concerns about regulatory review is that it has permitted the Executive Office effectively to usurp EPA's decisionmaking authority. The president's appointment and removal powers guarantee that his views will carry considerable weight with his appointees at EPA. However, the president does not have the authority to direct EPA officials to contravene statutory directives, ${ }^{200}$ and his ability to dictate the substance of EPA decisions may be circumscribed by statutes delegating decisionmaking authority to EPA. Concern over legal constraints on the exercise of the president's supervisory authority has carefully shaped the structure of each administration's regulatory review program. Each program has sought to preserve, at least on paper, the notion that Executive Office oversight will not displace the decisionmaking authority of the EPA administrator.

Regulatory review has made it more difficult for EPA to issue regulations, however, and Executive Office reviewers have consistently sought to make the regulations EPA does issue less stringent. This is hardly surprising since regulatory review was developed as a mechanism to temper the impact of environmental regulation. What is surprising is the dearth of evidence to suggest that regulatory review has resulted in truly significant improvements in EPA regulations.

Regulatory review has inspired EPA to increase its analytic capabilities, which has increased its ability to withstand pressure from the Executive Office. Although the review process has clearly had some impact on the substance of EPA decisions, the magnitude of that impact is open to debate. An EPA official observed in 1976 that QOL review had produced regulations that were "more reserved, more scientifically aggressive, less environmentally aggressive." 201 An EPA assistant administrator claimed that the changes resulting from QOL review "tend to be fairly small" and that he knew of "no case where a regulation has been gutted."'202 "Delays and fairly marginal

199. See, for example, Environmental Defense Fund $v$ Thomas, 627 F Supp 566 . The Justice Department has recently asked a federal district court to extend the judicial deadline for promulgating a new source performance standard for municipal incinerators for 30 days to allow EPA to revise the regulation as a result of the Council on Competitiveness's decision to uphold OMB's rejection of EPA's proposed recycling requirement. New York v Reilly, No 89-1729 (D DC 1991). The judicial deadline was imposed as an outgrowth of a settlement agreement between NRDC and EPA in New York $v$ Thomas, No 87-1463 (DC Cir 1987).

200. See, for example, National Federation of Federal Employees v Brown, 645 F2d 1017, 1025 (DC. Cir 1981) ("Under the structure of government-the separation of powers-established by the Constitution, the president has no authority 10 alter policy and principles declared by Congress even if, at the time the president acts. signals from Congress suggest it would approve the president's action.").

201. 7 Envir Rptr (BNA) al 693 (cited in note 33).

202. Id. 
changes are the usual result" of QOL review, concluded another EPA official. ${ }^{203}$

Clearly, however, regulatory review is designed to increase the ability of the Executive Office to influence the actions of agency heads. When disputes between EPA and the Executive Office arise, it has often been unclear who retains ultimate authority over regulatory decisions. In 1976, EPA Administrator Russell Train confirmed that the issue had never been finally resolved because "no regulation has ever been so vigorously opposed by OMB, and so strongly backed by EPA, that the issue has been raised."204 Were the issue to arise, "Train said EPA would insist on having final say, in part to protect what he sees as the 'regulatory integrity' of the agency in the eyes of the public, the Congress, and other federal agencies.'205 In response to Train, OMB staff told reporters that they agreed that "EPA would have final say on whether to adopt a specific regulation," and they cited an example of a regulation that Train had promulgated despite OMB opposition. ${ }^{206}$

Under the Carter Administration program, the Executive Office lacked the authority to block regulations indefinitely when disputes arose during regulatory review. Yet considerable political skirmishing occurred nonetheless as the reviewers tried to persuade agencies to modify their regulations.

What has happened in practice, in any event, is that enforcement of the regulationreview programs has consisted of political skirmishing within the executive branch, with the staff agencies of the Executive Office of the President (CWPS, CEA, and RARG) conducting economic search-and-destroy missions against the line regulatory agencies, stalking through the Federal Register and the accumulating regulatory analyses after proposals that appear particularly costly, ill-advised, or politically vulnerable. ${ }^{207}$

Because review did not take place until after a regulation had been proposed and the reviewers had no authority to delay a final decision, the choice of which regulations to review depended in part on whether the reviewers thought their input could have an impact in a relatively short period of time. ${ }^{208}$

Under the Reagan and Bush Administrations' review programs, agencies have been directed to refrain from publishing rules until after OMB has completed its review. OMB has used this authority to gain virtual veto power over EPA regulations, as indicated by the fact that only a handful of regulations ever have been promulgated over OMB's objections. ${ }^{209}$ In an effort to maintain its image as "the toughest kid on the block," OMB officials

203. Id at 694 .

204. Id at 696 .

205. Id.

206. Id at 696-97 (selective enforcement audit regulations for the auto industry).

207. DeMuth, 4 Regulation at 18 (cited in note 6 ).

208. Cost Hearings at 45 (cited in note 73) (CWPS selects as its "targets new proposals with (1) large costs (generally over $\$ 100$ million in any year), and (2) the prospect that we can have a useful policy impact through a 1- to 3-month review.") (testimony of Thomas D. Hopkins).

209. See notes 134-39 and accompanying text. 
admit that they "yell and scream, jump up and down, do whatever we can to get [the agencies] to listen to us." 210

Statistics released by OMB indicate that EPA is one of the agencies whose regulations are most frequently modified during the review process. Less than half of the EPA regulations reviewed by OMB in 1989 were approved without change (ninety-seven of 201 , or 48 percent). OMB approved 29 percent (fifty-nine of 201) of the EPA regulations after changes were made; returned 11 percent for reconsideration; and suspended review of 4 percent. EPA withdrew 5 percent of the regulations it submitted for review. ${ }^{211}$ Only the Departments of Housing and Urban Development and Labor (which includes OSHA) had smaller percentages of regulations approved without change in 1989.

TABLE 2

Actions Taken on EPA Rules by Percentage

\begin{tabular}{|c|c|c|c|c|c|c|}
\hline Year & $\begin{array}{c}\text { Total } \\
\text { Reviews }\end{array}$ & $\begin{array}{l}\text { Consistent } \\
\text { Without } \\
\text { Change }\end{array}$ & $\begin{array}{c}\text { Consistent } \\
\text { with } \\
\text { Change }\end{array}$ & $\begin{array}{c}\text { Withdrawn } \\
\text { or } \\
\text { Returned }\end{array}$ & $\begin{array}{l}\text { Dead- } \\
\text { line }\end{array}$ & Other \\
\hline 1984 & 302 & $74.5 \%$ & 20.9 & 4.3 & 0.3 & 0.3 \\
\hline 1985 & 302 & 66.2 & 28.5 & 4.3 & 0.7 & 0.3 \\
\hline 1986 & 197 & 66.5 & 24.9 & 6.1 & 1.5 & 1.0 \\
\hline 1987 & 205 & 60.0 & 29.3 & 4.4 & 5.9 & 0.5 \\
\hline 1988 & 210 & 51.0 & 27.6 & 6.2 & 14.8 & 0.5 \\
\hline 1989 & 201 & 48.3 & 29.4 & 8.0 & 11.9 & 2.5 \\
\hline
\end{tabular}

Source: OMB, Regulatory Program of the United States Government 1985, 1986, 1987, 1988, 1989, 1990.

Table 2 contains a summary of OMB's statistics on actions taken on EPA regulations from 1984 through 1989. These statistics do not accurately measure the significance of OMB's impact on the substance of EPA decisions, however. OMB's statistics combine both proposed and final rules and therefore understate the proportion of all rules that are modified during the review process. ${ }^{212} \mathrm{OMB}$ now appears to be returning rules to EPA for reconsideration somewhat more frequently (eleven in 1989 versus one in 1984), which may reflect OMB's heightened sensitivity to charges that it uses delay as a tool to displace agency decisionmaking authority. ${ }^{213}$ The declining percentage of EPA regulations approved without change can be accounted for by OMB's more frequent exemption of regulations from review due to statutory or judicial deadlines. The total percentage of regulations modified,

210. Bedell Says OMB Uses Pressure to Shape Environmental Rulemaking; Thomas Sees Budget Office Role as Legitimate But Says He Has Final Say, 16 Fnvir Rptr (BNA) 2050 (March 7, 1986).

211. Exec Order 12291, Annual Report for 1989, reprinted in OMB, Regulatory Program at 636 (cited in note 145) (numbers are rounded). See also Table 2.

212. Joseph Cooper \& William F. West, Presidential Power and Republican Government: The Theory and Practice of $O M B$ Rerieu of Agency Rules, $50 \mathrm{~J}$ Politics 864, 875 (1988).

213. This may represent somewhat of a return to OMB's previous more aggressive stance toward EPA regulations. During the period from 1981-83, OMB returned 34 rules to EPA for reconsideration and 24 were withdrawn during review. Id at 875 . 
withdrawn, or returned for reconsideration has increased only slightly in recent years.

Even in cases where rules are not modified during the review process, the anticipation of OMB review can have a subtle, but powerful, influence on the substance of EPA rulemaking proposals. In 1976, an EPA official said "[t]here is a 'perceived threat' hanging over all EPA regulations . . . concerning reactions to those regulations by both $\mathrm{OMB}$ and other federal agencies. The result ... is that EPA attempts to anticipate other agencies' reactions to regulations before EPA completes the draft proposal."214

Erik Olson's study confirmed that the Reagan regulatory review program did influence EPA's rulemaking:

The Executive Order has effectively institutionalized OMB input, especially where $\mathrm{OMB}$ has a strong policy interest. Of course, most rules receive little $\mathrm{OMB}$ attention. It is, however, OMB's goal to induce in EPA staff the understanding that rules in certain form will never clear OMB, and therefore should not even be sent there for review. This goal seems to have been at least in part achieved. ${ }^{215}$

Disputes between the Executive Office and EPA usually have been resolved through a frequently adversarial bargaining process. Because the QOL process in the Nixon and Ford Administrations focused on interagency review, EPA officials often had to defend their proposals against criticisms by representatives of other agencies with competing interests. Then, as now, disputes often centered on uncertainties concerning estimates of environmental impacts and the costs of regulation. In his description of QOL review of EPA's original lead phasedown regulations, John Quarles explains:

As usual, basic disagreements existed concerning the severity of the health risks, as well as the fuel penalties that might result from the regulations. It also was entirely typical that the participants in the final round of interagency argument were not experts in these issues. Yet we all argued with vehemence that the questions should be so resolved as to give maximum protection to the concerns within our spheres of responsibility. 216

EPA is not entirely without leverage in bargaining with OMB. The agency's expertise and powerful congressional and public support for its environmental mission give it some bargaining power. ${ }^{217}$ While OMB has recently returned EPA rules for reconsideration more aggressively, EPA has shown some willingness to endure a lengthy battle with OMB when it considers a regulation particularly important. By leaking details of the dispute to congressional committees and the public, EPA can generate external pressure on OMB, as EPA did recently during an extended dispute over standards for corrective action for hazardous waste facilities. 218

214. 7 Envir Rptr (BNA) at 693, 694 (cited in note 33).

215. Olson, $4 \mathrm{Va} J$ Nat Res $L$ at 50 (cited in note 136).

216. Quarles, Cleaming Lp America at 140 (cited in note 23)

217. Cooper \& West, $50 \mathrm{~J}$ Politics at 877 (cited in note 212)

218. At his confirmation hearing on February 1, 1989, EPA Administrator William Reilly pledged that "If OMB has not completed its [then four-month] review by the time I am sworn in as Administrator, I will take the necessary steps to quickly resolve the remaining issues and have the rule published promptly." Reauthorization of OMB's Office of Information and Regulatory Affairs, Hearings before the Senate Committee on Governmental Affairs, 101 st Cong, 2d Sess 752 (1990) 
Because of the enormous public support that currently exists for environmental protection, EPA has generally succeeded when it has gone public with major disagreements with OMB. Although the use of media attention as a strategic device has its limits, ${ }^{219}$ congressional pressure on OMB has also helped EPA win some battles. ${ }^{220}$ EPA rarely has suffered the humiliation that OSHA did when OSHA acceded to OMB's last minute insistence that it delete a short-term exposure limit from its ethylene oxide regulations. ${ }^{221}$ EPA nearly suffered such an embarrassment when it initially decided to accede to OMB's request to refer the asbestos phaseout rule to OSHA, a decision EPA ultimately reversed as a result of congressional pressure. ${ }^{222}$ EPA's decision to delete a recycling requirement from a new source performance standard for municipal incinerators at the request of the Competitiveness Council represents an important exception. ${ }^{223}$

When regulatory review is conducted outside public view, it is easier for $\mathrm{OMB}$ to influence the outcome of regulatory decisions. The QOL review of EPA's original lead phasedown regulations illustrates how an agency supposedly assured of its independence gave in to intense pressure from the

("Reauthorization Hearings"). Nearly a year later, the committee requested documents concerning discussions between OMB and EPA and issued a press release criticizing the continued delay. The regulation was cleared several months later. See EPA Releases Delayed Corrective Action Rule, Calls It "Milestone" in Cleanup of RCRA Facilities, 21 Envir Rptr (BNA) 475 (July 13, 1990).

219. Marcus, Environmental Protection Agency, in Wilson, ed, The Politics of Regulation at 287 (cited in note 21 ) (noting that Ruckelshaus followed an explicit strategy of courting favorable media attention in order to increase EPA's independence from White House influence, and that the strategy worked in the short run particularly because it energized EPA staff but the media's short attention span made it of less value for the long-term implementation problems).

220. When asked for information by Congress concerning an agency position that OMB is apt to oppose, EPA employees often send Congress material without OMB clearance either by transmitting unsigned and undated copies of letters or by leaking material to the press. 7 Envir Rptr (BNA) at 697 (cited in note 33) ("The practice is well enough understood in Washington that some congressional staffers ask for EPA's position prior to OMB clearance as well as its position following that clearance."). EPA also allegedly has used "guidance" documents to avoid OMB review of positions that would be subject to review if issued as regulations. See id (citing EPA's January 6, 1976 "legal interpretation and guideline" stating that tall smokestacks or other supplementary air pollution control systems would be permitted only for complying with the Clean Air Act by sources that also employ best available control technology).

221. OSHA had submitted an EtO standard to OMB that included a short term exposure limit ("STEL") 24 hours before a court-ordered deadline for promulgation. When OMB objected to the STEL, OSHA simply crossed out all references to it in the draft rule sent to the Federal Register for publication, without explaning the reasons for its deletion. The DC Circuit subsequently struck down OSHA's failure to include a STEL in the regulation as unsupported by the record. Tyson, 796 F2d 1479 .

222. See Asbestos Hearings (cited in note 162). Congress, of course, is not always the champion of EPA or environmental concerns. Some members of Congress "are very comfortable passing broad, remedial legislation, but also willing to bend to the desire of powerful regulated industries by ensuring that rules needed to carry out such legislation are never effectively implemented, or at most impose minimal burdens on the industries." Morrison, 99 Harv L Rev at 1071 (cited in note 173); see also William H. Rodgers, Jr., The Lesson of the Red Squirel: Consensus and Betrayal in the Enzironmental Statutes, 5 J Contemp Health 1. \& Policy 161 (1989) (legislators pursue strategies that hide provisions in "consensus" environmental legislation that later will undercut its effective implementation); W'illiam H. Rodgers, Jr. The Lesson of the Owl and the Crows: The Role of Deception in the Evolution of the Environmental Statmes, 4 J Land Lise \& Envir L. 377 (1989).

293. See note 170 and accompanying texı. 
Executive Office, agreeing to OMB's demand for a one-year delay in the regulations hours before they were issued in compliance with a court order. ${ }^{224}$

Under the Reagan/Bush regulatory review program, the pressure on agencies to satisfy OMB's concerns can be intense. If $\mathrm{OMB}$ refuses to approve a rule without the requested modifications, the agency may face an indefinite delay in the issuance of the regulation, and, in effect, usurp EPA decisionmaking authority. While noting that the president was entitled to a "certain degree of deference" in exercising his supervisory authority, a federal court has noted that

the use of Executive Order 12291 to create delays and to impose substantive changes raises some constitutional concerns. Congress enacts environmental legislation after years of study and deliberation, and then delegates to the expert judgment of the EPA Administrator the authority to issue regulations carrying out the aims of the law. Under Executive Order 12291, if used improperly, OMB could withhold approval until the acceptance of certain content in the promulgation of any new EPA regulation, thereby encroaching upon the independence and expertise of EPA. Further, unsuccessful executive lobbying on Capitol Hill can still be pursued administratively by delaying the enactment of regulations beyond the date of a statutory deadline. ${ }^{225}$

Concerns about displacement of EPA decisionmaking have been given new force by the Competitiveness Council's veto of EPA Administrator William Reilly's proposal to require municipal incinerators to recycle a portion of the waste streams they receive. Although OMB previously had approved a proposed EPA regulation that contained the recycling requirement, OMB refused to approve it in the final regulation. ${ }^{226}$ EPA then appealed OMB's decision to the presidential council. Prior to the council's meeting on December 19, 1990, Reilly supported the recycling requirement, which he had touted as an indication of EPA's commitment to stimulating greater recycling efforts. Following the council meeting, however, Reilly withdrew the requirement because of objections from the council. ${ }^{227}$ Under these circumstances, it is clear that OMB and the Council on Competitiveness clearly affected the substance of an EPA regulation in a significant manner. Whether this illustrates illegal displacement of EPA decisionmaking is less clear.

Although it seems unlikely that Reilly was simply persuaded by the council that inclusion of the recycling requirement was not warranted on the basis of the administrative record before EPA, the EPA Administrator has been very careful to state that he now accepts the consensus that the recycling

224. Quarles, Cleaning Up America at 138 (cited in note 23) ("I pointed out that the modified standards would accomplish our basic objectives; not only would they defuse the potentially explosive confrontation with the White House, but they would strengthen our defensive position against attacks by the oil industry, and its supporters in Congress, that we were being irresponsible in the face of the sharpening oil crisis."). Quarles nonetheless believes that regulatory review by OMB has been a useful mechanism for forcing EPA and other agencies to reach more balanced results that are sufficiently sensitive to competing economic and social values. Id at 142 .

225. Environmental Defense Fund v Thomas, 627 F Supp at 570.

226. 56 Fed Reg 5488 (1991).

227. Weisskopf, Washington Post at A17 (cited in note 170). 
requirement not be promulgated. ${ }^{228}$ Thus, he apparently has taken the position that the final decision to withdraw the recycling requirement was his. Although it is likely that Reilly's true motivation for withdrawing the regulations is that he did not want to risk being fired by the President for defying representatives of the Executive Office, courts are reluctant to sustain challenges to regulations based on questioning of the decisionmaker's motivations. ${ }^{229}$ Moreover, courts are eager to avoid what the District of Columbia Circuit has characterized as "difficult constitutional questions concerning the executive's proper role in administrative proceedings and the appropriate scope of delegated power from Congress to certain executive agencies." 230

This judicial deference would tolerate potentially severe intrusions by OMB or the Council on Competitiveness on the substance of EPA decisionmaking judgments, but it would not remove all constraints on the Executive Office's ability to influence EPA policymaking. The EPA administrator can always take his case to the public, threaten to resign, or even defy the Executive Office and run the risk of being fired. Each of these strategies would increase the political costs of Executive Office intervention. The true magnitude of these costs depends on the public reputation of the EPA administrator. ${ }^{231}$ Russell Train employed this strategy with some success during the Nixon Administration. ${ }^{232}$ Presidents who seek to acquire or enhance reputations as supporters of strong environmental protection will not lightly intervene to weaken EPA regulations.

The requirements that agency decisions must be consistent with the underlying regulatory statutes and supported by evidence in the administrative record place further constraints on the ability of the Executive Office to displace EPA decisionmaking. The Executive Office cannot legally dictate a result that is inconsistent with the regulatory statute or the rulemaking record. If the agency accedes to a change in a regulation dictated by $\mathrm{OMB}$ which is not supported in the record, the action may be struck down if challenged in court. ${ }^{233}$

228. Id.

229. Courts traditionally have not permitted private parties to conduct discovery that "probes the mind of the [government] decisionmaker." See United States "Morgan, 304 US 1 (1937).

230. Public Citizen Health Research Group v Tyson, 796 F2d at 1507.

231. Ironically, the loss of a highly publicized battle with the Executive Office can enhance the EPA administrator's reputation in the environmental community, as occurred when William Ruckelshaus's proposal for a modest acid rain control program was vetoed by the Reagan White House in 1984 .

232. See note 64 and accompanying text. For example, President Nixon was criticized by environmentalists when he fired Secretary of Interior Walter Hickel who had become an aggressive advocate of environmental protection efforts. When the Interior Department then tried to issue relaxed oil spill regulations sought by the White House, William Ruckelshaus, who was awaiting confirmation as EPA administrator, blocked the initiative by complaining that he should have a voice in the matter. Faced with rumors that Ruckelshaus's confirmation hearings could be delayed by congressmen upset over the Interior Department's initiative, the White House agreed to have the regulations pulled back. E. W. Kenworthy, Revision Delayed in Oil Spill Code. NY Times I col 7 (Dec I, 1970).

233. See Public Citizen Health Research Group v Tyson, 796 F2d 1479 (DC Cir 1986). 
Decisions reached at the behest of Executive Office reviewers are likely to be more vulnerable to judicial challenge than are other regulations because regulatory review usually emphasizes different factors than do the statutes and the administrative record. For example, the decision by the Council on Competitiveness to reject EPA's incinerator recycling proposal was reportedly based on grounds that are not necessarily relevant to the establishment of new source performance standards. ${ }^{234}$ An unidentified observer at the closed meeting said that the chief basis for the decision was philosophical: "There was the strong sense that they needed to give business something. Business has a lot of concern that we lost our commitment to deregulation." 235

\section{Secrecy and Public Participation in the Rulemaking Process}

Because they were designed to prevent agency inertia and capture by regulated industries, the federal environmental laws enacted during the last two decades encourage broad public participation in the rulemaking process. During both of his terms as EPA administrator, William Ruckelshaus emphasized the importance of public participation. Noting that citizens must be well-informed "[i]n order to participate intelligently in regulatory proceedings," Ruckelshaus instructed EPA "to make the fullest possible disclosure of information, without unjustifiable expense or delay, to any interested party."'236 During his second term as EPA administrator, Ruckelshaus declared that he would operate the agency as a "goldfish bowl." This policy represented a conscious effort to overcome damage done to the agency's credibility by the scandal that led to the resignation of Administrator Burford.

The openness that EPA has long pledged for its rulemaking proceedings has not extended to the regulatory review process. While prominent in the early years of the Reagan Administration's program, fears that regulatory review could serve as a back channel for private interests to influence rulemaking outside the public record existed from the inception of the Nixon Administration's program. Indeed, the Nixon Administration had created an extraordinary mechanism for facilitating secret industry lobbying by establishing the National Industrial Pollution Control Council ("NIPCC'). The explicit purpose of this body, which was composed entirely of corporate executives, was to provide industry input on environmental regulation. ${ }^{237}$ The deputy assistant secretary of commerce, who served as executive director of NIPCC, told a Senate oversight committee in 1972 that the council allowed

234. A press release issued by the Council cited three reasons for the decision: (1) the recycling requirement was not a performance standard, (2) the regulation interfered with local government decisionmaking, and (3) it was not cost-beneficial under Executive Order 12291.

235. Weisskopf, Washington Post at A17 (cited in note 170).

236. William Ruckelshaus, The Citizen and the Environmental Regulatory Process, 47 Ind L. J 636, 637 (1972).

237. See notes $12-15$ and accompanying text. 
companies to comment on draft environmental regulations before they were released for public comment. ${ }^{238}$ A former OMB official explained that

[NIPCC] was made up exclusively of industrial leaders, who met in secret, refused access to both reporters and environmental groups, and was quite clearly an illegal inside track for business leaders to oppose regulations they did not like. It was not just that OMB let the Commerce Department review EPA's regulatory proposals, but that the industrial community itself was getting a direct and illegitimate bite at them before they were even announced as proposals so that other affected groups could comment. ${ }^{239}$

After discovering that NIPCC would be meeting on October 14, 1970, representatives of ten consumer and environmental groups showed up at the Department of Commerce and sought to attend the meeting. The Commerce Department not only refused to allow them to attend the meeting, but it also refused their request to receive a transcript. ${ }^{240}$ This refusal required an express waiver of the provisions of Executive Order 11007, designed to prevent collusion by corporate executives meeting as members of federal advisory committees. ${ }^{241}$ Executive Order 11007, an outgrowth of antitrust concerns over advisory committees formed during the Korean War, ${ }^{242}$ required that a verbatim transcript be kept of all meetings of industry advisory committees. ${ }^{243}$ The Secretary of Commerce had waived this requirement by finding that it would interfere with the proper functioning of NIPCC, ${ }^{244}$ which William Rodgers describes as a "highly dubious" claim that undermined the council's credibility. ${ }^{245}$

Because of the secrecy that surrounded its operation, it is difficult to assess what impact NIPCC had on EPA regulations. Rodgers cites two examples where EPA policies were inexplicably altered to conform with positions taken by NIPCC. 246 He notes that by providing a vehicle for top corporate executives to assemble to plot a coordinated strategy for responding to

238. 1970 Clean Air Act Hearings at 581 (cited in note 13) (statement of Walter A. Hamilton).

239. Eads \& Fix, Relief or Reform? at $269 \mathrm{n} 9$ (cited in note 26) (Letter from Richard N. L. Andrews to George C. Eads, Jan 18, 1984).

240. E. W. Kenworthy, U.S. Pollution Control Panel Bars Environmental and Consumer Observers, NY Times $40 \mathrm{col} 2$ (Oct 15, 1970). Commerce Department officials also refused a request for a press conference. Noting that Commerce Secretary Maurice Stans had cited NIPCC as evidence of his department's concern for the environment, a representative of the Public Interest Research Group asked, "What have they got to hide?" NIPCC subsequently released summary minutes of some of its meetings. See 1970 Clean Air Act Hearings at 583-94 (cited in note 13). These summaries, however, amounted to little more than "a skeletal outline of the issues discussed, evidently thoroughly sanitized." William H. Rodgers, Jr., The National Industrial Pollution Control Council: Advise or Collude?, 13 BC Indust \& Comm L Rev 719, 727 (1972).

241. 3 CFR 573 (1959-63 comp).

242. Rodgers, 13 BC Indust \& Comm L. Rev at 722 (cited in note 240).

243. 3 CFR 575 (1959-63 comp).

244. 1970 Clean Air Act Hearings at 598 (cited in note 13).

245. Rodgers, 13 BC Indust \& Comm L Rev at 725 (cited in note 240).

246. Rodgers cites changes sought in air pollution regulations by the Mining and Non-Ferrous Metals Sub-Council of NIPCC and the September 1971 reversal of the government's policy to discourage use of phosphates in detergents in accordance with the requests of NIPCC's Detergents Sub-Council. Id at 734-43. 
environmental regulations, NIPCC supplied valuable "inside-track opportunities" for industry to redirect environmental policies. ${ }^{247}$

Members of NIPCC sought to justify the need for secrecy by arguing that disclosure would chill the free exchange of advice. ${ }^{248}$ Yet, as Rodger notes, this rationale is particularly dubious when applied to contacts by private industry with government officials. As reflected in Executive Order 11007, disclosure had been viewed as necessary to prevent private industry from engaging in collusive practices as members of federal advisory committees. "When members of an industry set out to influence their government, they should be required to do so publicly." 249

Congressional oversight committees and environmental groups made similar criticisms of regulatory review during the Ford and Carter Administrations. In 1976, a staffer for a House oversight committee complained that the secrecy surrounding QOL reviews unfairly tilted the regulatory process in the direction of industrial interests. He stated that regulatory review has "provided industry with an opportunity to review, comment on, delay, and change EPA actions behind closed doors. The public has not been afforded this opportunity and consequently faces industryinfluenced and weakened guidelines, regulations, and standards difficult to modify." 250

Although the Carter Administration's RARG review program involved submissions to the public rulemaking dockets, environmental groups charged that White House staff repeatedly met with EPA officials to influence regulatory decisions after the close of the public comment period. A lawyer for an environmental group told a congressional committee that as a result of these meetings:

we have two rulemakings that are going on within EPA on significant issues. We have one which is a public rulemaking, and we have another one which is a private rulemaking, a shadow rulemaking, if you will. A rulemaking which is characterized by little or no record, by secret meetings behind closed doors and by no opportunity for public comment or rebuttal. ${ }^{251}$

Concerned over the secrecy of the regulatory review process, Congress sought to force greater disclosure of the Executive Office's role in regulatory decisions when it amended the Clean Air Act in 1977. Congress amended the Act to require that drafts of proposed and final regulations sent to OMB for review be placed in the rulemaking docket ${ }^{252}$ so that the public can determine how, if at all, the regulations were changed during the review process. The amendment also requires that all documents accompanying such drafts and all written comments on the drafts from other agencies, and responses from

247. Id at 743

248. Id at 725

249. Id at 747 .

250. 7 Envir Rptr (BNA) at 695 (cited in note 33).

251. Executive Branch Hearings at 58 (cited in note 110) (testimony of Robert Rauch, staff attorney, Environmental Defense Fund).

252. 42 USC $\$ 7607$ (d)(4)(B)(ii) (1977). 
EPA, be placed in the rulemaking docket. However, a study of regulatory review during the Reagan Administration found that OMB and EPA often ignored these docketing requirements. ${ }^{253}$

The history of regulatory review demonstrates that the visibility of the review process can have an important impact on its outcome. ${ }^{254}$ Presidents have been reluctant to intervene directly in the rulemaking process because Congress and the public tend to be suspicious of such intervention. ${ }^{255}$ Concerns that the Reagan Administration was trying to conceal the regulatory review process from public scrutiny forced OMB to agree to progressively more liberal disclosure policies.

In June 1981, OMB Director David Stockman issued a memorandum directing OMB staff to advise members of the public that "relevant factual materials submitted to them should also be sent to the agency for inclusion in the rulemaking record." 256 This policy did little to defuse criticism that OMB was serving as a back channel conduit for industry input into regulatory decisions. In May 1985, EPA and OMB agreed that OMB would routinely send to EPA copies of documents concerning agency rulemakings that OMB had received from members of the public. While rejecting creation of a "logging requirement" that would inform EPA of contacts between OMB and members of the public, OMB pledged to inform EPA's general counsel whenever a meeting or phone call with an outside party provided OMB with factual information that OMB officials were not confident was provided to EPA. ${ }^{257}$ These policies had little effect on the amount of information available to the public concerning OMB's review of EPA regulations.

Faced with a congressional threat to eliminate funds for OMB's Office of Information and Regulatory Affairs, ${ }^{258}$ on June 13, 1986, OMB announced a new disclosure policy. ${ }^{259}$ The policy pledged to make available for public examination, upon written request made after publication of proposed or final regulations, the drafts of regulations sent to OMB for review. OMB also pledged to release all written correspondence exchanged between OIRA and

253. Olson, 4 Va J Nat Res $L$ at 59-60, 71, 73 (cited in note 136).

254. See notes $110-15,162$ and accompanying text.

255. See notes 108-10 and accompanying text. See also Paul J. Quirk, Food and Drug Administration, in Wilson, ed, The Politics of Regulation at 212 (cited in note 21) (describing how an administration attempt to intervene in an FDA decision backfired when news leaked to Congress and concluding that this "is the kind of exception that proves the rule: it suggests that attempts to intervene in favor of industry are likely to be politically unrewarding").

256. Stockman Memorandum (cited in note 145).

257. Letter from Robert P. Bedell to A. James Barnes (May 30, 1985), reprinted in OMB, Regulatory Program at 619 (cited in note 145).

258. See Judith Havemann, House Moves to Wipe out OMB Unit, Washington Post A23 (July 31, 1986).

259. Memorandum from Wendy L. Gramm (then-OIRA administrator), Additional Procedures Concerning OIRA Reviews under Executive Orders Nos 12291 and 12498 (June 13, 1986) (outlining the disclosure policy). The policy was amended on August 8, 1986 to clarify that it would apply only to regulations for which OMB completed review subsequent to June 13, 1986. Memorandum from Wendy L. Gramm, Revised June 13, 1986 Memorandum on Certain New Procedures of the Office of Information and Regulatory Affairs (Aug 8, 1986). 
an "agency head," as well as information on the dates it commenced and completed reviews of proposed and final regulations.

The new policy allows scrutiny of "unfiltered" regulations and enables determination of what changes were made after their submission to OMB for review. However, the policy is unlikely to provide the public with specific information concerning bargaining between OMB and EPA except in an unusual case where OIRA communicates in writing with the EPA administrator ${ }^{260}$ Indeed, EPA refused to permit the inclusion in a rulemaking docket of documents obtained by a congressional oversight committee relating to OMB's review of EPA's proposed revision of the National Contingency Plan. ${ }^{261}$ Although EPA normally includes any information submitted by outside parties, the agency argued that disclosure of the information "would harm EPA's ability to engage in frank and open discussions with $\mathrm{OMB}$ in matters such as these, thereby injuring the quality of agency decisions."'262

Moreover, the new disclosure procedures do not apply to regulations blocked by $\mathrm{OMB}$, and $\mathrm{OMB}$ refuses to disclose the status of regulatory reviews until after it has cleared final regulations. A sharply divided District of Columbia Circuit sitting en banc ruled that a log indicating when regulations were sent to OMB for review is exempt from disclosure under the Freedom of Information Act. ${ }^{263}$ The circuit held that exempt as material that is predecisional and deliberative, reasoning that disclosure of whether a regulation had been sent to OMB for review "will generally disclose the recommended outcome of the consultative process at each stage of the process, as well as the source of any decision not to regulate." 264 The court expressed fear that disclosure of such information would allow parties to identify and publicize agencies and officials responsible for regulatory delays, leading to "hasty and precipitous decision-making." 265 Noting that plaintiffs "seek access to the information, in part to issue themselves an invitation to agency deliberations," the court stated that agencies need not operate in a fishbowl. ${ }^{266}$ Thus, the public does not have a ready vehicle for determining what has happened to regulations indefinitely delayed by OMB.

260. The Superfund National Contingency Plan at 11 (cited in note 196) (under OMB's new disclosure policy "the details of $O M B$ 's communications with agency officials are largely hidden from public view" because 15 oral conversations between EPA and OMB officials and OMB's written comments on EPA's proposed plan never appeared in the rulemaking docket).

261. Porter Blocks Dingell Effort to Put Documents into Docket that Allegedly Show OMB Influence, 19 Envir Rptr (BNA) 2115 (Feb 10, 1989).

262. Letter from EPA Assistant Administrator J. Winston Porter to Congressman John Dingell (Feb 6, 1989), reprinted in The Superfund National Contingency Plan at 2 (cited in note 196).

263. Wolfe "Department of Health and Human Services, 839 F2d 768 (DC Cir 1988).

264. Id at 775 (footnote omitted). The court majority likened the information that a regulation had been sent to OMB for review to a slip of paper "memorializing a [judicial] panel's tentative decision by stating 'Reverse; I will write." Id.

265. Id at 776 .

266. Id. 
IV

\section{The Congressional Backlash Against Executive Office OVERSIGHT}

One of the most ignored, but significant, consequences of regulatory review has been its contribution to intensifying institutional competition between the presidency and Congress for control of federal policymaking. The concept of regulatory review by the Executive Office was developed during President Nixon's unprecedented efforts to expand presidential policymaking authority through administrative action. ${ }^{267}$ As the White House staff grew in size and influence, Congress expanded the size of its own bureaucracy and developed new devices for asserting its influence. ${ }^{268}$ With Congress and the presidency long under the control of opposite political parties, partisan rivalry has exacerbated the institutional rivalry for control over environmental policy.

Alarmed by the impact of regulatory review on the implementation of ambitious environmental legislation, Congress has become increasingly aggressive in attempting to influence EPA's implementation of the environmental laws. The hearings held by Senator Muskie's committee in 1972 to explore the impact of QOL review on implementation of the Clean Air $\mathrm{Act}^{269}$ presaged the intensified congressional oversight of EPA that was to follow.

Despite institutional and partisan rivalries, Congress has supported some aspects of Executive Office oversight and specifically endorsed participation by CWPS in agency rulemaking proceedings. ${ }^{270}$ Congressional hostility toward regulatory review has focused largely on concern that such review delays implementation of the laws and induces agencies to base regulatory decisions on factors not identified as relevant by the statutes. Even when Congress and the presidency were in the hands of the same political party, congressional committees did not hesitate to embarrass the president by holding oversight hearings to explore White House intervention in EPA regulatory decisions. ${ }^{271}$

The Reagan Administration's "regulatory relief" program has generated the most vociferous congressional reaction. It has resulted not only in intensified congressional oversight of EPA, but also in amendment of the already action-forcing environmental laws to constrain EPA's discretion even

267. Nixon's efforts to reorganize the Executive Office of the president to increase its control over the federal bureaucracy are described in Nathan, The Plot that Failed at 45 (cited in note 28). An important part of these efforts was the creation of OMB by executive order on July 1, 1970, and a doubling of the size of the White House staff during Nixon's first term. Sidney M. Milkis \& Michael Nelson, The American Presidency 313-14 (Cong Q Press, 1990).

268. For exaniple, OMB's growing influence and the controversy caused by President Nixon's assertion of authority to "impound" appropriated funds resulted in Congress's creation of the Congressional Budget Office through the Congressional Budget and Impoundment Control Act of 1974 .

269. See notes $43-52$ and accompanying text.

270. See note 72 and accompanying text.

271. Sce note 110 and accompanying text. 
more severely. By championing "regulatory relief" at a time when there was genuine interest in Congress in "regulatory reform," the Reagan Administration review program sacrificed an opportunity to improve substantially the structure of environmental regulation.

The action-forcing structure of the environmental laws has constrained EPA's flexibility from the start. Beginning with the Clean Air Act in 1970, statutory deadlines, technology-forcing regulatory mandates, and citizen suit provisions in the laws have restricted the agency's ability to decide what to regulate and how to regulate it. Despite the acknowledged inefficiencies of this approach, its proponents argued that it was justified on the ground that a national assault on long-neglected environmental problems had to be jumpstarted to achieve success. ${ }^{272}$

By 1980, after nearly a decade of experience with federal environmental regulation, there was substantial interest in improving its structure. The Carter Administration's Regulatory Council sought to begin improving the efficiency and effectiveness of regulation by encouraging EPA's development of an emissions trading, or "bubble," policy and by exploring other regulatory innovations. ${ }^{273}$ Congress was receptive to measures to reduce unnecessary regulatory burdens, as indicated by its enactment of the Paperwork Reduction Act and the Regulatory Flexibility Act ${ }^{274}$ at the close of the Carter Administration and the Senate's approval of "regulatory reform" legislation 275 at the outset of the Reagan Administration. However, under the Reagan Administration's regulatory program, OMB's efforts to roll back environmental regulation provoked Congress to amend the laws to incorporate more demanding and increasingly explicit regulatory directives.

The congressional backlash toward the Reagan program was a direct consequence of the manner in which the administration chose to implement its strategy for providing "regulatory relief." Rather than seeking new legislation to modify environmental laws that it found objectionable, the Reagan Administration sought to effect major change in federal environmental policies by dramatic administrative initiatives. Viewing these actions as threats to legislative prerogatives, Congress responded by increasing its own "micromanagement" of EPA. In short,

[t]he various elements of the Reagan regulatory relief strategy that played so well politically during the first few months of the administration-the freeze on effective dates for rules, the regulatory hit lists, the appointment of politically attuned rather than professionally competent administrators, the targeted budget cuts and personnel actions, the meetings with business groups to the virtual exclusion of any other

272. In 1977, outgoing EPA Administrator Russell Train told a congressional oversight subcommittee that although this approach "carries with it certain penalties in terms of efficiency, both technological efficiency and economic efficiency ... up to now these have been costs that have been well worth paying in order to get the country moving on these programs." Status Hearing at 9 (cited in note 25).

273. Innovative Techniques in Theory and Practice: Proceedings of a Regulatory Council Conference 21 (now defunct U.S. Regulatory Council, July 22, 1980).

274. Paperwork Reduction Act of 1980, 44 USC $\S 101$ (1980); Regulatory Flexibility Act, 5 USC $\$ 601(1980)$.

275. S 1080 (cited in note 154). 
interested parties-all tended to undermine the perception that the Reagan Administration could be counted on to use in a reasonable way any additional discretion it might be granted. Indeed, the opposite impression was created. Congress was put in a mood to tighten, not loosen, the "regulatory ratchet" and to scrutinize every action of administration regulatory officials. ${ }^{276}$

While it is impossible to tell how much of Congress's intensified oversight of EPA is a response to regulatory review, OMB's impact on the agency is cited frequently as a justification for Congress's actions. ${ }^{277}$ A study of congressional oversight by the National Academy of Public Administration found that between 1984 and 1986, EPA officials had been summoned to appear at 198 hearings held by twenty-six different congressional committees. ${ }^{278}$

The Reagan program has itself been a subject of several investigations by congressional oversight committees. These investigations have produced numerous hearings ${ }^{279}$ and congressional committee reports sharply critical of the program. ${ }^{280}$ More significantly, Congress has expressed its dissatisfaction with the consequences of regulatory review by adding more specific statutory controls on agencies' discretion every time it has reauthorized the environmental laws.

The result has been a distinct trend toward reduced flexibility for agencies charged with implementing the federal environmental statutes. ${ }^{281}$ This congressional desire to control agency discretion is reflected in an increase in the proliferation of statutory deadlines and the specification of more detailed substantive criteria in such legislation. ${ }^{282}$ Shapiro and Glicksman have noted that such congressional efforts to control agency discretion employ three models: a coercive model under which the agency's discretion concerning whether or not to regulate is removed while the agency is permitted to choose the appropriate method of regulation; a prescriptive model under which the agency retains its regulatory discretion but must regulate in accordance with

276. Eads \& Fix, Relief or Reform? at 256 (cited in note 26).

277. Congressional Oversight of Regulatory Agencies: The Need to Strike a Balance and Focus on Performance 29 (Natl Acad Pub Admin, 1988) ("Oversight is necessary, from the committee staff member's perspective, because of the power of OMB and the Reagan Administration's 'deep hostility toward effective environmental regulation." ") ("NAPA, Congressional Oversight").

278. Id at 22 .

279. See, for example, OMB Hearings (cited in note 121); OMB Control of OSHA Rulemaking, Hearings before a Subcommittee of the House Government Operations Committee, 97th Cong, 2d Sess (1982); EPA Investigation Hearings (cited in note 141); Asbestos Hearings (cited in note 162); Oversight of the OMB Regulatory Review and Planning Process, Hearing before the Subcommittee on Intergovernmental Relations of the Senate Committee on Governmental Affairs, 99th Cong, 2d Sess (1986) ("OMB Oversight Hearing”); OMB Review of EPA Regulations, Hearings before a Subcommittee on Oversight \& Investigations of the House Committee on Energy \& Commerce, 99th Cong, 2d Sess (1986).

280. See, for example, Asbestos Hearings (cited in note 162); OMB Influence on Agency Regulations (cited in note 183); The Superiund National Contingency Plan (cited in note 196).

281. See generally Richard J. Lazarus, The Neglected Question of Congressional Oversight of EPA: Quis Custodiet Ipsos Custodes (Who Shall Watch the Watchers Themselves)?, 54 L \& Contemp Probs 205 (Autumn 1991); Richard J. Lazarus, The Tragedy of Distrust in the Implementation of Federal Environmental Law, 54 L \& Contemp Probs 311 (Autumn 1991).

282. Sidney A. Shapiro \& Robert L. Glicksman, Congress, the Supreme Court, and the Quiet Revolution in Administrative Law, 1988 Duke L J 819. 
relatively detailed substantive criteria if it chooses to regulate; and a ministerial model, which couples a statutory deadline with a detailed substantive standard defining the appropriate manner of regulation. ${ }^{283}$

OMB's impact on agency decisions is frequently cited in the legislative history that accompanies the enactment of more detailed statutory controls on agency discretion. For example, when Congress amended the Endangered Species Act in 1982 to remove much of the secretary of interior's discretion to refuse to add species to the endangered list, the Conference Committee report explained that the amendments were intended to preclude application of Executive Order 12291 and the Paperwork Reduction Act to listing decisions. ${ }^{284}$

The congressional backlash against the administration's regulatory policies is illustraced most dramatically by the 1984 Hazardous and Solid Waste Amendments, which impose dozens of new deadlines for regulatory action, occasionally accompanied by hammer provisions that specify the default regulations that will take effect automatically if EPA fails to meet a deadline. ${ }^{285}$ While this legislation was in part a response to the scandal that led to the resignation of EPA Administrator Burford, it also was clearly a response to congressional frustration with OMB's role in the regulatory review process. The House Committee report on the 1984 amendments specified that EPA's ability to meet "this deadline as with all other deadlines in this bill, shall not be impaired in any way whatsoever by Executive Order $12291 ., 286$

The 1986 Superfund amendments also illustrate this phenomenon. As one congressman remarked when explaining the myriad deadlines and directives in the final version of the Superfund Amendments and Reauthorization Act of 1986: "It limits the discretion of the EPA and OMB to procrastinate, delay or thwart the will of Congress and the American people."287

Congress has also used the threat of legislative action to counter OMB efforts to block EPA regulatory initiatives. For example, in September 1985 it was revealed that $\mathrm{OMB}$ had been blocking EPA's efforts to promulgate

283. Id.

284. See Endangered Species Act Amendments of 1982, HR Conf Rep No 835, 97th Cong, 2d Sess 20 (1982). "The 1982 revision of listing procedures was intended as a direct slap at the performance of the Reagan Administration, and in particular its application to the listing process of 'regulatory impact analyses' under Executive Order 12291 . . . "Michael J. Bean, The Evolution of National Wildlife Law 336 n77 (Praeger, 1983).

285. See Richard C. Fortuna \& David J. Lennett, Hazardous Waste Regulation: The New Era 10-13 (McGraw Hill, 1987) (describing the history of EPA's failures to meet previous deadlines for promulgating federal hazardous waste regulations implementing RCRA); see also J. William Futrell. Hazardous Wastes and Toxic Substances: Lessons from Superfund, RCRA, and Other Environmental Laus, 24 Houston L Rev 125, 134 (1987) (calling the RCRA Amendments a "classic example of intergovernmental distrust" that is "lengthy and unparalleled in the[] level of detail, intrusion into EPA's management practices, and prescription of new' regulatory practices").

286. Hazardous Waste Control and Enforcement Act of 1983, HR Rep 98-198, House Committee on Energy \& Commerce, 98th Cong, 1st Sess 35 (1983).

287. 132 Cong Rec H9599 (Oct 8, 1986) (Rep. Scheur). 
maximum contaminant levels for forty substances in drinking water. In response, the Senate adopted an unusual amendment that required OMB to release the proposal. ${ }^{288}$

Not surprisingly, Congress's increasing use of statutory deadlines has not been popular with EPA officials, despite the fact that many of the deadlines "were negotiated [by Congress] with EPA, and modified at EPA's behest."289 Some EPA officials have questioned whether Congress has limited their discretion so severely as to "impinge upon the constitutional authority of the executive branch to establish and implement its own regulatory agenda.",290 Others have noted that environmental legislation is becoming like the tax code in which "the administrative discretion of the [IRS] is severely proscribed by hundreds of specific congressional directives that mandate special treatment of favored localities and certain industries."291

The congressional backlash against OMB review is not the only factor contributing to the trend toward increasingly prescriptive environmental legislation. The demise of the legislative veto in INS $v$. Chadha ${ }^{292}$ has removed from the congressional arsenal what had been one of Congress's favorite tools for influencing agency action. Thus today, as the Supreme Court noted in Bowsher $v$. Synar, once it has enacted legislation, "Congress can thereafter control the execution of its enactment only indirectly-by passing new legislation.', 293

The trend toward increasingly prescriptive environmental legislation is likely to continue until public and congressional confidence in EPA's independence is restored.

The Reagan Administration failed to realize that a crucial element in generating and sustaining the perception of a good-faith administration of social regulation is an open and relatively transparent process of regulatory decision-making, including regulatory oversight as exercised by the White House. . . . Indeed, a regulatory decision-making process that is (or merely appears to be) biased to favor any one interest group (especially the entities supposedly being regulated) invites Congress and the courts to further constrain existing administrative discretion and to engage increasingly in second-guessing individual administrative actions. Given the nature of the issues involved, the potential for arbitrary decisions and abuse of discretion is so inherently great in social regulation that faith in the fairness of the decision-making process is an absolute prerequisite to increased regulatory flexibility. ${ }^{294}$

While EPA has suffered the brunt of the congressional backlash against regulatory review, OMB is becoming a target as well. In 1986, Democratic committee chairmen in Congress threatened to eliminate funding for OIRA.

\footnotetext{
288. Senate Accepts Amendment to Superfund Bill to Force OMB to Release Drinking Water Rules, I6 Envir Rptr (BNA) 933 (1985).

289. Fortuna \& Lennett, Hazardous Waste Regulation at 16 (cited in note 285).

290. F. Henry Habicht, II, Responses to Justice Antonin Scalia, 24 Houston L Rev 111,116 (1987).

291. Futrell, 24 Houston L Rev at 133 (cited in note 285).

292. 462 US 919 (1983).

293. 478 US 714, 733-34 (1986) (striking down provisions in the Gramm-Rudman-Hollings Deficit Reduction Act that delegate certain functions to the Comptroller General on the ground that they violate separation of powers principles by authorizing a legislative branch official to perform executive functions).

294. Eads \& Fix, Relief or Reform? at 258-59 (cited in note 26).
} 
Although they did not succeed in eliminating OIRA's appropriation, Congress did seek to restrict OIRA's activities to performing reviews under the Paperwork Reduction Act. In language added to OMB's appropriations bill, Congress specified that funds appropriated for OIRA be used for "the review of a rule or regulation ... only to the extent that such review is for the sole purpose of reviewing an information collection request contained in, or derived from, such rule or regulation."295 OIRA, however, was able to continue performing regulatory reviews under the executive orders (following an internal reorganization) by using funds available to OMB for other purposes. More recently, Congress's insistence that reauthorization of the Paperwork Reduction Act be accompanied by new limits on OMB review has resulted in expiration of that act due to a last minute hold placed on the legislation by Republican senators opposed to the deal worked out between the White House and congressional leaders. ${ }^{296}$

The activities of the Bush Administration's Competitiveness Council have itensified congressional resentment of Executive Office review. In early 1991 congressional committees held two lengthy oversight hearings to explore the council's role in Executive Office interference with EPA's implementation of the Clean Air Act. Members of Congress denounced the council's actions in weakening EPA regulatory proposals as "sinister," "Orwellian," "a serious breach of the separation of powers," and dubbed the council "a polluter star chamber."'297

\section{$\mathrm{V}$ \\ Executive Office Oversight: A Legal and Policy Assessment}

The Reagan Administration's regulatory review program has sparked considerable commentary that seems almost schizophrenic in its assessment of Executive Office oversight. ${ }^{298}$ While scholars have praised the theoretical desirability of improving regulatory policy through regulatory review, critics

295. 44 USC $\$ 3520$, as amended by Paperwork Reduction Reauthorization Act, Title VIII, $\$ 820$, Pub L No 99-500, 100 Stat 1783 (1986).

296. See note 167 and accompanying text.

297. Jeffrey H. Birnbaum, While House Competitiveness Council Provokes Sharp Anger Among Democrats in Congress, Wall St J A8 col 1 (July 8, 1991).

298. See, for example, Harold H. Bruff, Presidential Management of Agency Rulemaking, 57 Geo Wash L Rev 533 (1989); Thomas O. McGarity, Regulatory Analysis and Regulatory Reform, 65 Tex L Rev 1243 (1987); Robert V. Percival, Rediscovering the Limits of the Regulatory Review Authority of the Office of Management and Budget, 17 Envir L Rptr 10017 (1987); Peter L. Strauss \& Cass R. Sunstein, The Role of the President and $O M B$ in Informal Rulemaking, 38 Admin L Rev 181 (1986); Christopher C. DeMuth \& Douglas H. Ginsburg, White House Review of Agency Rulemaking, 99 Harv L Rev 1975 (1986); Morrison, 99 Harv L Rev at 1059 (cited in note 173); Olson, 4 Va J Nat Resources L 1 (cited in note 136); Douglas M. Costle, Environmental Regulation and Regulatory Reform, 57 Wash L Rev 409 (1982); Cass R. Sunstein, Cost-Benefit Analysis and the Separation of Powers, 23 Ariz L Rev 1267 (1981); Norton Rosenberg, Beyond the Limits of Executive Power: Presidential Control of Agency Rulemaking under Executive Order 12291, 80 Mich L. Rev 193 (1981). 
have charged that the Reagan program has served as a vehicle for immeasurable abuses. ${ }^{299}$

Some controversy over regulatory review is virtually inevitable in light of institutional and partisan rivalries that exist in a system of government with separation of powers. The schizophrenic assessments of regulatory review stem not only from differences between theoretical and empirical perspectives on its purposes and effects, but also from different attitudes toward regulatory policy in general. ${ }^{300}$ Thus, any assessment of regulatory review must examine carefully not only the rationales for regulatory review but also the models of regulatory policy upon which those rationales are founded.

\section{A. Rationales for Regulatory Review}

Regulatory review has been defended on both procedural and substantive grounds. The rationale most frequently offered in support of regulatory review is that it improves interagency coordination and increases accountability for regulatory decisions. ${ }^{301}$ A more controversial rationale is that it improves the substance of regulatory policy by requiring that regulatory decisions satisfy certain substantive criteria, such as cost-benefit analyses. ${ }^{302}$ This second rationale is founded on competing diagnoses of agency failure that are a source of considerable controversy.

\section{Enhanced Coordination and Increased Accountability. Improved interagency} coordination was a major rationale for the development of the first regulatory review program. In October 1971, then-OMB Director Gecrge P. Shultz explained that the purpose of the QOL review program was to "establish a procedure for improving the inter-agency coordination of proposed agency regulations, standards, guidelines, and similar materials pertaining to environmental quality, consumer protection, and occupational and public health and safety." 303 The programs that followed in subsequent administrations also have emphasized the desirability of minimizing duplication of effort and increasing agency accountability. ${ }^{304}$

The regulatory review programs employed during the Nixon, Ford, and Carter Administrations facilitated interagency coordination by using the

299. See, for example, Morrison, 99 Harv L Rev at 1064 (cited in note 173) (noting that "the system of OMB control imposes costly delays that are paid for through the decreased health and safety of the American public ... [,] places the ultimate rulemaking decisions in the hands of OMB personnel who are neither competent in the substantive areas of regulation, nor accountable to Congress or the electorate in any meaningful sense[, and] operates in an atmospinere of secrecy and insulation from public debate that makes a mockery of the system of open participation embodied in the Administrative Procedure Act.").

300. See Bruff, 57 Geo Wash L Rev at 565 (cited in note 298) (While most of the debate over regulatory review has focused on regulatory procedures, "the real disagreement usually concerns the substance of regulatory policy.").

301. See, for example, Strauss \& Sunstein, 38 Admin L Rev at 189-91 (cited in note 298).

302. See, for example, DeMuth \& Ginsburg, 99 Harv L Rev at 1080-1082 (cited in note 298).

303. 7 Envir L Rptr (BNA) at 693 (cited in note 33).

304. Sce, for example, Fxec Order 12291 preamble, 3 CFR 127 (1982); Exec Order 12498 preamble, 3 CFR 323 (1986). 
Executive Office as a clearinghouse for comments solicited from other agencies. The semiannual Regulatory Calendar initiated in the Carter Administration (called a Regulatory Agenda in subsequent administrations) also has improved interagency coordination. While the Reagan and Bush programs have deemphasized interagency comments by centralizing review responsibility in OMB, the annual Regulatory Program put together under Executive Order 12498 also facilitates coordination of regulatory action. ${ }^{305}$

Supporters of regulatory review by the Executive Office maintain that the president is in the best position to coordinate the overall scheme of regulation by federal agencies and to hold agency personnel accountable. They note that the proliferation of federal regulatory agencies in the last two decades has made coordination imperative and that the president is directly accountable to the electorate. Based on the assumption that OMB possesses a broader perspective on environmental protection than EPA, they maintain that the regulatory review process permits a more balanced accommodation of the competing values affected by regulatory proposals. ${ }^{306}$

Even critics of regulatory review acknowledge that improved coordination and increased accountability are desirable goals. They argue, however, that these have not been the principal aims of regulatory review, particularly during the Reagan Administration. ${ }^{307}$ Moreover, they note that there is an inherent tension between the breadth and depth of regulatory review that poses a dilemma for any review program. While the president may be in the best position to enhance accountability, virtually no regulatory review is conducted by the president or his close advisers; instead it inevitably must be delegated to lower-level staff, particularly in a system like the Reagan program in which all regulatory actions are reviewed routinely. One reason regulatory review had consistently been so controversial in previous administrations is that it is inherently selective in nature. ${ }^{308}$ While only the president has a sufficiently broad mandate to integrate and coordinate the activities of all regulatory agencies, the White House can not become involved in every regulatory issue. The "necessary selectivity inevitably raises the suspicionsometimes with very good reason-that political considerations rather than a desire to achieve coordination have been the primary reason that a particular regulation has been singled out for attention." 309

John Quarles has argued that even the QOL review process, which reviewed only selected EPA regulations, undermined accountability and

305. See Strauss \& Sunstein, Admin L Rev at 187 (cited in note 298) (explaining that Executive Order 12498 may facilitate the oversight capacity of agency heads by allowing them to supervise their staffs' development of an annual regulatory plan).

306. See, for example, id at 187-90.

307. See, for example, Morrison, 99 Harv L Rev at 1064 n22 (cited in note 173) (noting that "OMB can perform some useful functions in the rulemaking process . . ." including "coordinating related proceedings between agencies ..." and ensuring that relevant information is shared between agencies and that agencies consider the needs of small business as required by the Regulatory Flexibility Act).

308. Eads \& Fix, Relief or Reform? at 46 (cited in note 26).

309. Id. 
diffused responsibility by requiring staff from EPA to negotiate regulatory issues with subordinate staff from other agencies and OMB. He concluded that

it is preferable to rely on the political process to hold the Administrator accountable rather than to create complex mechanisms which attempt to establish additional checks and balances within the executive branch, but which also inevitably fragment responsibility and in the end undermine achievement of the very accountability for which those mechanisms are established. ${ }^{310}$

By requiring that all regulations be submitted to OIRA for review, the executive orders respond to the selectivity issue by sacrificing some of the visibility and accountability of overt selective regulatory review and entrusting any necessary selection to OIRA's desk officers. Critics question whether these reviewers have an institutional perspective that is broader than EPA's. They note that in performing its review function, OIRA has focused almost exclusively on the cost of regulation and its economic impact. ${ }^{311}$ Concerns also have been raised that OIRA staff lack the technical expertise required to analyze health and safety issues. ${ }^{312}$ By contrast, EPA's program offices are charged by law with responsibility for considering a broad range of values implicated by environmental policy decisions, including public health and welfare effects and ecological impacts. ${ }^{313}$

Some argue that OMB staff need not be "experts" because their primary job is to ask hard questions "that a sophisticated layman would ask."314 Yet it is clear that many of OIRA's reviews involve the assessment of scientific and technical information, ${ }^{315}$ and that the reviewers are rewarded in part on how successful they are in generating reasons for disapproving of regulation. As a former OIRA desk officer confessed to congressional investigators:

I didn't have the technical expertise to work on EPA issues. I would receive studies on both sides of a [toxics] issue and I just didn't know [how to evaluate the conflicting arguments]. I knew I would do well from my boss' perspective if I got rid of rules on [the toxic substances]. ${ }^{316}$

310. Executive Branch Hearings at 4 (cited in note 110 ).

311. See, for example, Morrison, 99 Harv L Rev at 1065 (cited in note 173).

312. In January 1986, OMB reported that only one of OIRA's 82 staff members had a degree in a health-related field; most have backgrounds in economics, business, or finance. OMB Oversight Hearing at 180 (cited in note 279) (table with testimony of OMB Director Miller). While the statistics reported indicate that $25 \%$ of the staff had prior work experience in a health-related field, it is unclear how significant such work experience had been since the OIRA staff on average are reported as having had work experience in nearly four different fields. Id.

313. See, for example, the Toxic Substances Control Act, §6(c)(1), 15 USC § 2605(c)(1), the source of EPA's regulatory authority to ban asbestos products. This statute requires EPA, before regulating chemicals, to consider and to make findings concerning the chemicals' health effects, magnitude of human exposure, magnitude of environmental exposure and environmental effects, benefit of the chemical for various uses, availability of substitutes, and "the reasonably ascertainable economic consequences of the rule, after consideration of the effect on the national econmomy, small business, technological innovation, the environment, and public health."

314. DeMuth \& Ginsburg, 99 Harv L Rev 1083-84 (cited in note 298).

315. Olson, 4 Va J Nat Res $\mathrm{L}$ at 14 (cited in note 136).

316. OMB Influence on Agency Regulations at 19 (cited in note 183) (comment included in committee report). 
Serious questions about OIRA's competence to handle complex scientific issues have been raised as a result of one of the few instances when OIRA's substantive views on regulatory policy have been articulated publicly. When it prepared the annual Regulatory Program of the United States Government for the 1991 fiscal year, OIRA staff inserted a section containing remarkably harsh criticism of risk assessment policies employed by federal agencies. ${ }^{317}$ The document argued that risk assessment practices employed by federal agencies typically overestimate risks by employing assumptions that are far too conservative. While risk assessment has been highly controversial and some scientists have raised concerns similar to those made by $O M B$, what was particularly disturbing about the OMB report was its lack of balance. ${ }^{318}$ The Harvard Center for Risk Analysis criticized OMB's presentation as "onesided," "misleading," and "confusing," and recommended that more balanced treatment of risk assessment issues be provided.319 This episode indicates that OIRA has not won sufficient respect in the scientific community to justify a major substantive role in shaping and coordinating federal risk assessment policy.

In order to be comprehensive, regulatory review inevitably involves delegation of responsibility to lower level staff who may not have a clear sense of the priorities of the president whom they purportedly represent. Thus, they may be inclined to impose their own personal preferences on agency decisions. As a RARG staffer confessed: "Since I never knew what decision the president would make, or would have made if an issue ever got to him, I had no choice but to pursue my own vision of what was good."320

One of the few examples that OIRA officials have cited to illustrate the benefits of improved coordination due to the regulatory review program is EPA's asbestos phasedown rule. ${ }^{321}$ DeMuth and Ginsburg note that OMB officials met with Canadian government officials "presumably in order to discuss not the scientific or technical issues, in which EPA is expert, but the foreign policy implications of the proposed rule." 322 They conclude that in such circumstances, "an agency with a broader perspective is better suited to represent the administration than the program agency in which rulemaking authority is lodged." 323

While a claim of foreign policy expertise for OMB seems far-fetched, ${ }^{324}$ it is particularly strained in the context of the asbestos example. The Canadian government, which has heavily promoted its asbestos industry, had requested

317. OMB, Regulatory Program at 13-26 (cited in note 145).

318. Comments on Office of Management and Budget, Current Regulatory Issues in Risk Assessment and Management 4 (Center for Risk Analysis, Harvard School of Public Health, Dec 17, 1990).

319. Id.

320. Landy, Roberts \& Thomas, EPA: Asking the Wrong Questions at 67 (cited in note 20).

321. DeMuth \& Ginsburg, 99 Harv L Rev at 1084 (cited in note 298).

322. Id at 1087 .

323. Id.

324. A subsequent OIRA administrator told an interviewer that "OMB tends to be much more domestically focused than internationally focused." OMB is "responsible for the budget of the State Department and the international agencies, but in terms of international policy development and 
the meeting with OMB after learning that EPA had decided to proceed with a proposal to ban most remaining uses of asbestos. ${ }^{325}$ OMB previously had tried to block this proposal by parroting the asbestos industry's argument that EPA should be required, as a matter of law, to refer asbestos risks to OSHA for regulation. ${ }^{326}$ A congressional oversight committee obtained a copy of a telex sent by the Canadian embassy to the Canadian External Affairs Department that revealed that OMB had encouraged Canadian opposition to EPA's proposed asbestos ban. The telex reported that "while OMB found it necessary for several reasons to approve the proposal, the agency remains opposed to [the] banning approach and it will actively work toward this end in the regulatory process." It noted that "OSHA regulation is a key element in [the] OMB plan to avoid banning" because OMB believed that if OSHA tightened the standard for workplace exposures, the benefits of an asbestos ban would be greatly reduced. ${ }^{327}$

While some may find it disturbing to learn OMB would confide to a foreign government that it planned to manipulate one federal agency against another to avoid regulation phasing out a toxic substance, the most unfortunate aspect of this incident is that it suggests that OMB had little genuine concern for achieving better interagency coordination of regulation. EPA had been considering an asbestos ban since 1979 because it believed that this was the most efficient way to control the extremely serious risks posed throughout the entire life cycle of asbestos use. ${ }^{328}$ OSHA, however, may not have the authority to ban products, since it is directed to set permissible exposure limits ("PELs") for workers as low as is "feasible" to protect worker health. ${ }^{329}$ While OSHA had proposed lowering its PEL for asbestos from two fibers per cubic centimeter of air to $0.2 \mathrm{f} / \mathrm{cc}$, it concluded that this would only reduce the cancer risk faced by exposed workers from sixty-four in 1000 to 6.7 in 1000 . OSHA considered a risk of nearly seven in 1000 to be unacceptably

review, OMB has historically not been a terribly big player in that area." 6 Envir Forum at 28 (cited in note 185 ).

325. The vast majority of the asbestos used in the United States came from foreign sources, principally Canada.

326. See Asbestos Hearings (cited in note 162). OMB had briefly persuaded EPA to refer asbestos risks to OSHA under $\S 9$ of TSCA, despite EPA's previous position that $\S 9$ did not require such a referral. After congressional oversight hearings were announced, EPA Administrator Lee Thomas conceded that the agency had made a mistake in announcing the referral OMB wanted, and EPA decided instead to proceed with its proposal to phaseout asbestos under $\S 6$ of TSCA. While one commentator has suggested that OMB review may serve as a kind of substitute for "hard look" judicial review of agency action, Peter L. Strauss, Considering the Alternatives to "Hard Look" Review, 1989 Duke L J 538, 548, one wonders whether OMB also should defer to EPA's interpretations of its statutory authority, since courts have been directed to do so by Chevron, U.S.A. v NRDC, 467 US 837 , 844 (1984).

327. OMB Review of EPA Regulations at $137-41$ (cited in note 279).

328. See 44 Fed Reg 60061 (Oct 19, 1979); 51 Fed Reg 3738 (Jan 29, 1986).

329. OSHA is required "in promulgating standards dealing with toxic materials or harmful physical agents" to "set the standard which most adequately assures, to the extent feasible, on the basis of the best available evidence, that no employee will suffer material impairment of health or functional capacity even if such employee has regular exposure to the hazard dealt with by such standard for the period of his working life." Occupational Safety \& Health Act $\S 6(b)$ (5), 29 USC $\S 655$ (b)(5) (1988) (emphasis added). 
high, but it concluded that this was the lowest feasible level to which worker exposure could be reduced given the present state of technology. ${ }^{330}$

Had OMB been seriously interested in coordinating regulatory action by EPA and OSHA, it would not have impeded EPA's asbestos phaseout proposal because it could have avoided the need for investments in extremely expensive occupational exposure controls that admittedly were inadequate to protect asbestos workers. Instead, OMB's actions succeeded in substantially delaying EPA's asbestos phaseout proposal. ${ }^{331}$ Thus, while there may be sound theoretical grounds for supporting regulatory review as a means for improving coordination and increasing accountability, in practice regulatory review has often worked against these goals.

2. Increasing the Net Benefits of Regulation. The Reagan Administration's regulatory review program had far broader goals than simply improving coordination and increasing accountability. It represented a sharp departure from its predecessors because it sought to require that regulatory decisions satisfy particular substantive criteria. ${ }^{332}$ The ostensible objective of the Reagan Administration's review program was to maximize the net societal benefits of regulation. A poorly disguised goal of the Reagan program was to use regulatory review as a tool for providing "regulatory relief" to industry. ${ }^{333}$ Despite the bitter criticism of the Reagan program, there is surprisingly little evidence to suggest that the program was successful on either count.

Clearly, OMB review has increased the cost of regulation by making it more difficult and expensive for EPA to issue regulations. The question is whether society is better off today as a result of incurring these increased costs and modifying or disposing of proposed EPA regulations. Although there is an extensive literature on regulatory review, remarkably few specific examples of dramatic benefits produced by OMB review have been offered.

While the Reagan program sought to make cost-benefit analysis the central guiding principle of the regulatory review program, the Reagan Administration never subjected the program itself to cost-benefit analysis prior to promulgation of the executive orders. This analysis apparently was

330. 51 Fed Reg 22612 (June 20, 1988); 53 Fed Reg 35610, 35611 (Sept 14, 1988).

331. EPA ultimately promulgated the asbestos phaseout regulation in somewhat modified form. 54 Fed Reg 29459, 29492 (July 12, 1989). OSHA's occupational exposure controls for lead are also clearly inadequate to protect workers against significant risks, as illustrated by one company's establishment of a "fetal protection" policy banning fertile women from workplaces because of the risk of lead exposure to fetuses. This policy was eventually overturned by the U.S. Supreme Court, citing "evidence in the record about the debilitating effect of lead exposure on the male reproductive system." Automobile Workers v Johnson Controls, Inc., 111 S Ct 1196 (1991), reversing, Int'l Union, UAW v Johnson Controls, Inc., $886 \mathrm{~F} 2 \mathrm{~d}$ 871, 874 (7th $\mathrm{Cir}$ 1989). In recognition of the pervasive risks posed by lead, EPA has indicated that it is conducting a "Regulatory Investigation of Lead" to explore the use of $\S 6(\mathrm{a})$ of TSCA for controling the lifecycle of risks from uses of lead. OMB, Regulatory Program at 469 (cited in note 145). See also Strategy for Reducing Lead Exposures (EPA, 1990). OMB reportedly has resisted EPA's efforts to implement this initiative. OMBB Doubls Over Lead's Health Risks May Threaten Future EPA Regs, Staff Say, 12 Inside EPA I (Feb 22, 1991).

332. See note 130 and accompanying text.

333. Fix \& Eads, 2 Yale J Reg at 312 (cited in note 161). 
deemed unnecessary despite OMB's nearly religious belief in cost-benefit analysis, because of the implicit assumption that anything that made regulation more difficult was an unambiguous good. ${ }^{834}$ By turning a blind eye to the potential benefits of regulation, the Reagan Administration seriously undermined the economic foundation of the regulatory review program by intertwining it in the administration's ill-fated crusade for regulatory relief.

One discernible impact of regulatory review is that it has stimulated more rigorous regulatory analysis by EPA. The Nixon Administration's QOL program played a major role in stimulating the early development of EPA's in-house analytic capabilities as well as the creation of a more formalized regulatory development and clearance process within the agency. ${ }^{385}$ Erik Olson's study of the impact of the Reagan Administration program found that "a more rigorous internal review has developed" within EPA. ${ }^{336}$ "EPA has beefed up its economic analyses" and "had spent $\$ 2.45$ million on a stilluncompleted ... RIA for the RCRA land disposal standards." 337

Not surprisingly, the extensive internal and external reviews that EPA regulations receive have been credited with improving their overall quality. ${ }^{338}$ The more difficult question is whether the benefits outweigh their additional costs. Paul Portney has argued that the costs EPA regulations impose are so enormous that if regulatory review results in even a small reduction in the cost of regulation, it will have more than paid for itself. ${ }^{339}$ While Portney's analysis supports having some form of regulatory review to ensure that regulations are not unnecessarily costly, it does not address the questions of how much economic analysis agencies should perform and who should conduct regulatory review. ${ }^{340}$

One of the ironies of the Reagan Administration's regulatory review program is that it adopts a command and control approach to regulatory review by requiring that all regulations be submitted to OMB for review and by prohibiting publication of regulations until OMB has completed this review. ${ }^{341}$ This has produced frequent complaints that OMB review has delayed regulation pending the development of information that is

334. See Scalia, 5 Regulation at 14, 17 (cited in note 138) (James C. Miller, III: regardless of how long review delays regulations, it is "necessary-and well worth it-to make sure that new rules do more good than harm").

335. Eads \& Fix, Relief or Reform? at 50 (cited in note 26).

336. Olson, 4 Va J Nat Res $\mathrm{L}$, at 49 (cited in note 136).

337. Id.

338. 7 Envir Rptr (BNA) at 694 (cited in note 33), quoting OMB and EPA officials as crediting the extensive review process with the excellent quality of most EPA regulations.

339. Paul R. Portney, The Benefits and Costs of Regulatory Analysis, in Kerry Smith, ed, Environmental Policy under Reagan's Executive Order 226-38 (U North Carolina Press, 1984).

340. Portney notes that CWPS studied the impact of its participation in 31 agency rulemaking proceedings during the Carter Administration and found that significant improvements in regulations had occurred in eight cases and moderate improvements in nine cases. Id at 234 . While Portney notes that CWPS did not attempt to measure the monetary benefits of its activities, it is conceivable that CWPS's approach to regulatory review, which had been expressly endorsed by Congress, generated substantial net benefits in the absence of a prepublication clearance requirement.

341. See note 125 and accompanying text. 
unnecessary or unhelpful. In his study, Erik Olson found that "in general, EPA staff interviewed believed that a full-blown cost-benefit RIA is of little value to EPA decisionmakers and is essentially a waste of EPA's scarce resources."342 As McGarity notes, "although regulatory analysis unquestionably has enhanced regulatory decision making in many instances, it also has led to some poor decisions;" 343 one of the "gravest threats to regulatory analysis is the perception that it is biased against regulation," ${ }^{444}$ a problem that has infected OMB's review program because of its association with the Reagan Administration's regulatory relief program. Shortly after announcing his plans to leave EPA, Administrator Lee Thomas complained that "OMB is important but they are more of a pain in the ass because it takes a long, long time to get anything through."345 Thomas conceded that regulatory review is generally necessary but complained that the reviews often resulted in unnecessary repetition of answers to questions that had already been settled within EPA. ${ }^{346}$

The expense of increased analytical study necessary for the regulatory review program has not been accompanied by an increase in EPA's budget. ${ }^{347}$ RIAs may cost several hundred thousand, if not millions, of dollars. ${ }^{348}$ At the same time the Reagan program was launched, the enactments of TSCA, RCRA, and CERCLA were expanding EPA's statutory responsibilities dramatically. ${ }^{349}$ Yet the Reagan Administration slashed EPA's budget. This exacerbated the gulf between EPA's responsibilities and resources. This gulf impeded innovations in market-based mechanisms that, although expensive to develop, could have provided society with real cost savings in the long term, and increased public and congressional distrust of EPA. ${ }^{350}$

Perhaps the most glaring problem with the Reagan Administration's regulatory review program was its lack of balance. From its inception, the program focused almost exclusively on reducing costs to industry. OMB's

342. Olson, 4 Va J Nat Res $L$ at $49-50$ (cited in note 136).

343. McGarity, 65 Tex L Rev at 1246 (cited in note 298) (citing the way cost-benefit analyses were used by the Army Corps of Engineers to justify virtually any development project). Compare CostBenefit Analysis Can Be Useful in Assessing Environmental Regulations Despite Limitations 13, 21 (U.S. Gen Acct Office, 1984) (finding that cost-benefit analysis could improve the quality of environmental regulations).

344. McGarity, 65 Tex L Rev at 1332 (cited in note 298).

345. Thomas Tells of Frustration with OMB. Predicts More Rules But Urges Prevention, 19 Envir Rptr (BNA) 1617 (Dec 9, 1988).

346. Id.

347. By requiring EPA to expend time and resources on further analysis, the executive orders reduce the remaining resources available to the Agency for promulgating rules. See McGarity, 65 Tex L Rev at $1270 \mathrm{n} 140$ (cited in note 298), citing Regulatory Reform Legislation of 1981, Hearings before the Senate Committee on Governmental Affairs, 97th Cong, Ist Sess 255 (1981) (statement of Lester Lave).

348. See Morrison, 99 Harv L Rev at 1066 (cited in note 173).

349. One indication of the expansion of EPA's statutory responsibilities is the growth of the cumulative page length of federal environmental statutes from approximately 200 to more than 400 pages between 1975 and 1980. Curtis Moore, Second Step on a Thousand Mile Journey: The Case for Creating a Department of Environmental Protection 56 (unpub manuscript, 1989) (copy on file with author).

350. Eads \& Fix, Relief or Reform? at 148-49 (cited in note 26). 
blindness to the potential benefits of environmental regulation is illustrated by the claim of the Task Force on Regulatory Relief that it had saved the economy 150 billion dollars in costs. This claim does not mean that net societal benefits increased by a corresponding amount because it fails to consider any of the benefits foregone by relaxing regulations. ${ }^{351}$ Even OMB's estimates of cost savings are exaggerated. Former OIRA Administrator Miller admitted that OMB's initial claim that regulatory review had saved nine to eleven billion dollars in capital expenditures and six billion dollars in recurring annual costs, was derived "mainly from industry sources" and that "it is conceivable" that OMB's efforts actually may have generated net costs. ${ }^{352}$ The claim that the task force saved 150 billion dollars over ten years is also suspect. Eads and Fix note that the task force counted transfers as cost savings, claimed credit for rescinding regulations that were unlikely ever to have been implemented, claimed credit for savings connected with regulations ordered reinstated by the courts, and employed double counting. ${ }^{353}$

This imbalance in the Reagan Administration's regulatory review program meant that it presumed that relaxation of environmental regulations could not possibly result in net costs to society. Because the program was premised on the notion that regulatory relief was urgently needed, Executive Office oversight of EPA has rarely focused on the very end emphasized by Executive Order 12291: maximizing net benefits to society. ${ }^{354}$ Rather, the Reagan Administration "principally used the system of OMB review created by the executive orders to implement a myopic vision of the regulatory process which places the elimination of cost to industry above all other considerations." 355 For example, OMB has interpreted Executive Order 12291's requirement that cost-benefit analysis be performed for "major" regulatory actions as applying only to actions that strengthen regulations, not to actions that repeal them. ${ }^{356}$ Thus, agencies must prepare RIAs before proposing to promulgate major regulations, but not when they are proposing to repeal them.

EPA's lead phasedown regulations provide the most stunning illustration of the potentially disastrous consequences of OMB's anti-regulatory bias. At the direction of the Task Force on Regulatory Relief, EPA in February 1982

351. Id at 245. The Task Force sought to justify this claim by arguing that "the changes have not sacrificed any values protected by the relevant statutes," Reagan Administration Regulatory Achievements 70 (Presidential Task Force on Regulatory Relief, Aug 11, 1983), a claim Eads and Fix dismiss as "clearly untrue." Eads \& Fix, Relief or Reform? at 245 (cited in note 26).

352. OMB Hearings at 114-15 (cited in note 121 ).

353. Eads \& Fix, Relief or Reform? at 237-45 (cited in note 26).

354. Exec Order $12291 \& 2$ (c), 3 CFR 127 (1982).

355. Morrison, 99 Harv L Rev at 1065 (cited in note 173).

356. This interpretation apparently stems from the fact that Executive Order 12291 defines a "major rule" only in terms of its effect on the economy (" $[A]$ ny regulation that is likely to result in an annual effect on the economy of $\$ 100$ million or more." Exec Order 12291 \$ (b)(1), 3 CFR 127 (1982)) and not in terms of its value in protecting human health or the environment. See also Miller, 1 Regulation at 14,17 (cited in note 66) (OIRA administrator states that relaxation of a major rule would be exempt from the RIA requirement). 
proposed to repeal existing limits on the amount of lead that could be used as an additive in gasoline. The proposal to relax or rescind the lead limits was cleared by OMB even though EPA had not performed an RIA and had not assessed the consequences to public health of increasing lead emissions. ${ }^{357}$ Despite OMB's vigorous support for this proposal, protests from the environmental and public health communities convinced EPA not to relax the lead limits. ${ }^{358}$ OMB later tried to claim credit for the reversal. ${ }^{359}$

The lead phasedown controversy startingly demonstrates that OMB's antiregulatory bias effectively precluded agencies from even contemplating whether a strengthening of environmental regulations would generate net benefits to society. Throughout the controversy, the Environmental Defense Fund argued that a cost-benefit analysis would demonstrate that sharp reductions in the lead content of gasoline would yield enormous net benefits. ${ }^{360}$ Indeed, evidence from the second National Health and Nutrition Examination Survey ("NHANES II") demonstrated a dramatic correlation between changes in levels of lead used in gasoline and levels of lead in children's blood. ${ }^{361}$ This evidence was so dramatic that the court reviewing EPA's decision not to relax the lead limits stated, in a highly unusual bit of dicta, that "the demonstrated connection between gasoline lead and blood lead [and] the demonstrated health effects of blood lead levels . . . would justify EPA in banning lead from gasoline entirely." 362

EPA did not consider strengthening the lead limits until more than a year later, when EPA's auto inspection survey revealed that misfueling with cheaper leaded gasoline had poisoned the catalytic converters in more than 12 percent of vehicles designed to burn unleaded gasoline. ${ }^{363}$ After it was suggested that the misfueling problem could be dealt with by phasing lead out of gasoline, EPA Deputy Administrator Al Alm initiated a cost-benefit analysis of further lead phasedown. ${ }^{364}$ EPA's analysis demonstrated that nearly $\$ 1$ billion in annual net benefits (mainly reduced medical care and automobile

357. EPA, Regulation of Fuel and Fuel Additives, 47 Fed Reg 7812 (1982) ("This proposed action is not 'major' under Executive Order 12291 in that it is not likely to have significant adverse economic impact and, therefore, is not subject to the requirement of a [RIA]," id at 7813 (emphasis added)).

358. A crucial and influential ally was conservative columnist George Will, who decried the administration's failure to consider the impact of increased lead emissions on the incidence of lead poisoning in children. George F. Will, The Poison Poor Children Breathe, Washington Post A23 (Sept $16,1982)$

359. Eads \& Fix, Relief or Reform? at 134 (cited in note 26) (referring to this as secking "to turn lemons into lemonade by citing the lead phase-down decision as a significant victory for the oversight process").

360. Comments of the Environmental Defense Fund on Proposals to Relax or Rescind Regulations Limiting the Lead Content of Gasoline 8-9, US EPA, Docket No A-81-36 (May 17, 1982).

361. Joseph L. Annest, et al, Blood Lead Levels for Persons 6 Months-74 Years of Age: United States, 1976-80, in II Vital Health Statistics No 233 (Natl Ctr Health Statistics Advance Data, May 12, 1982).

362. Small Refiner Lead Phase-down Task Force v EPA, 705 F2d 506, 531 (DC Cir 1983); see also the chart "Lead Used in Gasoline Production and Average NHANES II Blood Lead Levels," id at 528.

363. Costs and Benefits of Reducing Lead in Gasoline I-2 (EPA, 1984).

364. See Al Alm, The Multimedia Approach to Pollution Control: An Impossible Dream?, in Multimedia Approaches to Pollution Control: Symposium Proceedings (Natl Res Council, 1987). 
maintenance expenses) would result from virtually eliminating lead from gasoline. ${ }^{365}$ OMB did not seek to block EPA's subsequent proposal virtually to eliminate lead additives from gasoline. ${ }^{366}$

OMB's failure to consider the potential benefits of regulation also is illustrated by the decidedly asymmetrical way in which OMB has granted categorical exemptions from its regulatory review procedures. In general, OMB has only exempted from its review process those EPA actions that make regulations less stringent or that unconditionally approve state submissions that EPA cannot legally require to be weaker. Thus, EPA decisions increasing allowable pesticide tolerances are exempted from OMB review while decisions strengthening an existing tolerance are not exempted. ${ }^{367}$ Rules that unconditionally approve state water quality standards, State Implementation Plans under the Clean Air Act, or state underground injection control programs are exempt from review; decisions disapproving or imposing conditions on approval of such submissions are not exempted. ${ }^{368}$ Decisions approving hazardous waste delisting petitions or deleting pollutants from the list of toxic pollutants under section 307(a) of the Clean Water Act are exempt from review; decisions denying delisting petitions or adding pollutants to the list are not exempted. ${ }^{369}$

\section{Regulatory Review as a Response to Agency Failure. Proponents of regulatory} review have generally sought to justify such programs as a means for correcting systemic flaws in the structure of the regulatory process. The development of economic theories of bureaucracy that focus on the incentives of institutional actors ${ }^{370}$ has given rise to several different theories of agency failure, each involving a distinct diagnosis of the source of agency failure and dictating a distinct remedy. ${ }^{371}$

365. Costs and Benefits (cited in note 363). See Arthur Fraas, The Role of Economic Analysis in Shaping Environmental Policy, 54 L \& Contemp Probs 113, 120-21 (Autumn 1991).

366. OMB reportedly insisted that EPA eliminate from its subsequent lead phasedown proposal the option of banning lead additives from gasoline entirely, allowing OMB to assure the multitude of protesting antique car owners that EPA would not consider a ban on lead additives. Conversation of author with OIRA analyst Wayne Leiss. The dangers of a single-minded focus on reducing the cost of regulation are also illustrated by the fallout from the savings and loan scandal. When the chairman of the Federal Home Loan Bank Board told OMB that deregulation of financial institutions had created an urgent need for a doubling of the number of bank examiners, OMB's associate director reportedly "chided him for not understanding President Reagan's mission of trimming government and said he should be thinking about making do with fewer examiners rather than more." Besides $S$ E $L$ Owners, Host of Professionals Paved Way for Crisis, Wall St J A l, A4 (Nov 2, 1990).

367. Exec Order 12291, Annual Report for 1989, reprinted in OMB, Regulatory Program at 648 (cited in note 145).

368. Id.

369. Id at $648-49$

370. See James M. Buchanan \& Gordon Tullock. The Calculus of Consent (U of Mich Press, 1962); Anthony Downs, Inside Bureaucracy (Little, Brown, 1967).

371. Distinct theories of agency failure are derived from experiences with different kinds of regulation. They are "to a substantial degree irreconcilable," and they have very different implications for the design of a regulatory review program. Sunstein, 23 Ariz L. Rev at 1267, 1269-70 (cited in note 298) (citing theories of agency capture by regulated industry, agency vindictiveness against regulated industry, and agency self-aggrandizement). 
Proponents of the Reagan regulatory review program most frequently cite an agency failure theory that views regulatory agencies as captives of special interests that use them to "favor narrow, well-organized groups at the expense of the general public."372 DeMuth and Ginsburg explain why this view justifies centralized regulatory review under a cost/benefit standard:

\begin{abstract}
Without some countervailing restraint, EPA and OSHA would "spend"-through regulations that spend society's resources but do not appear in the federal government's fiscal budget- "too much" on pollution control and workplace safety. This tendency is reinforced by the "public" participation in the rulemaking process, which as a practical matter is limited to those organized groups with the largest and most immediate stake in the results. Although presidents and legislatures are themselves vulnerable to pressure from politically influential groups, the rulemaking process-operating in relative obscurity from public view but lavishly attended by interest groups-is even more vulnerable. ${ }^{373}$
\end{abstract}

While DeMuth and Ginsburg did not identify the specific interest groups that presumably have captured EPA, their thesis represents a dramatically different diagnosis than the original agency failure theories that focused on capture by regulated industries. The traditional agency capture theory implies that regulators will favor the interests of concentrated producer groups at the expense of the more diffuse interests of consumers. Applied to environmental regulation, this theory suggests that business interests would be more likely to "capture" EPA because the enormous potential compliance costs of regulation provide greater incentives to business for lobbying activities than the diffuse benefits of regulation provide to the general public. ${ }^{374}$ Traditional agency capture theory would predict that "statutes are underenforced or perverted, and the implementation process yields to regulated industries a victory they failed to obtain in Congress." 375

Environmentalists had long argued that mission-oriented agencies had become prime enemies of environmental protection because these agencies were the captives of business interests. In 1970 Joseph Sax argued that the New Deal model of entrusting policymaking to the expertise of "an incredible tangle of agencies with noble-sounding mandates and small budgets" had failed because the "expert" agency had supplanted the public to such an

372. DeMuth \& Ginsburg, 99 Harv L Rev at 1080 (cited in note 298). This theory originated in studies of economic regulation, see George J. Stigler, The Theory of Economic Regulation, 2 Bell J Econ \& Mgmt Sci 3 (1971), but has been extended by public choice theorists to social regulation as well. See Sam Peltzman, Toward a More General Theory of Regulation, $19 \mathrm{~J} \mathrm{~L} \mathrm{\&} \mathrm{Econ} 211$ (1976). While efforts to find empirical support for this theory in the field of environmental regulation have emphasized one case study involving a provision of the Clean Air Act that has subsequently been repealed, Bruce A. Ackerman \& William T. Hassler, Clean Coal/Dirty Air (Yale U Press, 1981), other examples probably can be found if for no other reason than environmental regulations inevitably create distributional impacts that can be viewed as creating winners and losers. Pollution, of course, also has a differential impact on different societal groups. See, for example, Annest, et al, Blood Lead Levels at 7-9 (cited in note 361) (reporting that levels of lead in children's blood are far higher among minority and low-income groups based on sample of more than 16,000 children in the NHANES II study).

373. DeMuth \& Ginsburg, 99 Harv L Rev at 1081 (cited in note 298).

374. James C. Miller, III, William F. Shughart, II \& Robert D. Tollison, A Note on Centralized Regulatory Review, 43 Pub Choice 83, 84 (1984).

375. Sunstein, 23 Ariz L Rev at 1269 (cited in note 298). 
extent that " $[\mathrm{t}]$ he public itself is thought to possess no expertise about the public interest."376 Thus the environmental legislation enacted by Congress in the 1970s sought to counteract agency capture by requiring agencies to incorporate environmental considerations in their decisionmaking and by authorizing citizen suits and judicial review to provide stricter judicial scrutiny of agency decisions. Indeed, as noted above, EPA was expressly structured as a single-mission agency to avoid capture by the regulated community. ${ }^{377}$

The notion implicit in DeMuth and Ginsburg's theory that the pendulum had swung to the point where EPA had become the captive of environmental groups contrasts sharply with the disappointment of environmental groups with EPA's failure to implement aggressively the early federal environmental legislation. The problems that were manifest in environmental regulation by 1980 included lengthy delays in issuing standards, widespread noncompliance by the regulated community, and an abysmal monitoring and enforcement system. ${ }^{378}$ As a result, Congress had resorted increasingly to the enactment of statutory deadlines in an effort to force more expeditious agency action. ${ }^{379}$

President Reagan clearly misjudged public demand for environmental regulation. ${ }^{380}$ As Eads and Fix note, the Reagan Administration fundamentally miscalculated by extrapolating from the experience of economic deregulation, where agency capture theories had considerable validity, to arrive at its belief that the public wanted to deregulate the environment.

In contrast, the failure of social regulation to achieve its stated goals was generally perceived not as a reflection of any fundamental flaw with either the goals or the regulatory techniques employed but as a failure of will. Various administrations just had not tried hard enough to make social regulation work. Trying harder, not scaling back programs, was seen as the generally acceptable solution. In such an environment, appointing administrators who were openly hostile to social regulation's goals and who, whether fairly or not, were perceived as prepared to do everything in their power to make certain that social deregulation did not work could hardly be expected to call forth cries for a scaling back of social regulatory programs. ${ }^{381}$

The administration responded to the public's chronic disappointment with EPA's performance by appointing executive officials who were hostile to the very environmental protection goals the public believed had not been

376. Joseph L. Sax, Defending the Environment: A Strategy for Citizen Action 60-61 (Alfred A. Knopf, 1970); see also Sierra Club v Morton, 405 US 727, 745-46 (1972) (Douglas dissenting) (reviewing literature concerning agency capture).

377. See notes $22-25$ and accompanying text.

378. Crandall \& Portney, Environmental Policy, in Portney, ed, Natural Resources and the Environment at $47-48$ (cited in note 148 ).

379. One study has found that federal environmental laws enacted between 1976 and 1980 added 200 new statutory deadlines for agency action. Statutory Deadlines in Environmental Legislation: Necessary but Need Improvement D-5 (Envir \& Energy Study Inst, 1985) ("EESI, Statutory Deadlines").

380. See Philip Shabecoff, Ruckelshaus Says Administration Misread Mandate on Environment, NY Times Al (July 27, 1983) (quoting William Ruckelshaus as saying that the Reagan Administration had confused the public's desire for better environmental regulation with a desire to lessen regulation).

381. Eads \& Fix, Relief or Reform? at 255 (cited in note 26). 
pursued aggressively enough. ${ }^{382}$ In these circumstances, Congress and the public perceived OMB not as a politically responsive champion of the public will, but rather as a dangerous guerilla challenging the fundamental premises of environmental regulation. ${ }^{383}$ Thus, it is not surprising that the Reagan Administration failed to achieve any fundamental change in the environmental statutes that it decried.

Another variant on the agency failure theory suggests that EPA has some kind of institutional bias in favor of "too much" regulation. This idea may stem from the perception that some of the statutes EPA administers contain unrealistically ambitious regulatory standards. ${ }^{384}$ Yet EPA's track record in implementing such legislation suggests that sufficient deterrents already exist to prevent it from regulating too extensively. The example usually used to illustrate this point is that EPA has regulated only seven hazardous air pollutants during the twenty years it has had to implement the provisions of Section 112 of the Clean Air Act. ${ }^{385}$ A similar pattern appears to prevail at OSHA. OSHA established new workplace exposure limits for only ten toxic chemicals during the same period that the private standard-setting organizations upon whose recommendations OSHA had relied in establishing its original standards lowered their recommended exposure limits for hundreds of chemicals. ${ }^{386}$

John Mendeloff argues that the slow pace of standard-setting is due in part to laws that require standards to be set too strictly. Asserting that "overregulation causes underregulation," he maintains that agencies are reluctant to implement laws that require standards to be set without regard to cost considerations. ${ }^{387}$ Although OMB's actions may have contributed to this pattern, Mendeloff's thesis suggests that larger political forces already deter agencies from implementing statutes perceived as requiring overly broad regulation, even in the face of explicit statutory directives.

An examination of EPA's performance in implementing some of its other statutory guides indicates that allegedly overbroad statutes cannot be the

\section{Id at 141.}

383. Perhaps public choice theorists could explain OMB's role as promoting quiet wealth transfers to industry supporters of the administration by making behind-the-scenes changes in regulations. In light of OMB's ideological emphasis on the principle of economic efficiency, its role could be viewed more benignly as an attempt to redress inefficiencies generated by democracys initial allocation of political power on the basis of a one person-one vote rule and to promote regulatory policies more consistent with the perceived products of dollar voting

384. See, for example, John Q. Dwyer, The Pathology of Symbolic Legislation, 17 Ecol L Q 233, 234$35(1990)$.

385. See id at $269 \mathrm{n} 154$. 42 USC $\$ 7412$. Congress has just amended the Clean Air Act to require that a list of 189 airborne toxics be regulated by EPA. 1990 Clean Air Act Amendments of 1990, § 301, Pub L No 101-549, 104 Stat 2533.

386. John M. Mendeloff, The Dilemma of Toxic Substance Regulation 2 (MIT Press, 1988). OSHA subsequently employed a generic rulemaking approach to update and establish permissible air exposure limits for 376 toxic substances in a single rulemaking that was completed with remarkable expedition. The final regulation adopted in January 1989, occupied an entire 650-page volume of the Federal Register. 54 Fed Reg 2332 (1989).

387. Mendeloff, The Dilemma of Toxic Substance Regulation at 8-11 (cited in note 386). See also Sunstein, 57 U Chi L Rev at 413-16 (cited in note 193) (endorsing Mendeloff's thesis). 
exclusive cause of underregulation. Two examples cited in Mendeloff's own study are revealing: EPA's experience implementing the Toxic Substances Control Act ("TSCA") and the Federal Insecticide, Fungicide, and Rodenticide Act ("FIFRA"). ${ }^{388}$ EPA regulated only four existing chemicals during TSCA's first decade and had completed reregistration under FIFRA of fewer than a dozen of the 600 active ingredients of pesticides in seven years. ${ }^{389}$ These examples are significant because both statutes require EPA to balance the environmental benefits of regulation against its economic impacts. 390 Moreover, TSCA requires EPA to employ the "least burdensome requirements" that will protect adequately against an unreasonable risk. ${ }^{391}$ Indeed, the structure of TSCA makes it, at least in theory, precisely "the kind of law that would encourage cross-media analysis and integrate environmental decisionmaking."392 EPA's difficulties in implementing risk-benefit balancing statutes suggest that factors other than a perception of unreasonable statutory commands are responsible for underregulation. ${ }^{393}$

388. TSCA, 150 USC $\S \S 2601$ et seq (1988); FIFRA, 7 USC $\S \S 136$ et seq (1988).

389. Mendeloff, The Dilemma of Toxic Substance Regulation at 2 (cited in note 386). See also Identifying and Regulating Carcinogens 134 (Office of Technology Assessment, 1987). EPA's testing program under TSCA is also abysmally behind schedule. A recent General Accounting Office report notes that in $1980 \mathrm{EPA}$ and the Interagency Testing Committee established by TSCA had identified 2,226 chemicals that might pose unreasonable risks. Yet the report found that "EPA has compiled complete test data for only six chemicals since the enactment of TSCA [in 1976] and has not finished assessing any of them." EPA's Chemical Testing Program Has Made Little Progress 3, 15 (Gen Acct Office, 1990).

390. See, for example, TSCA $\S 6(a)(c)(1)(D), 15$ USC $\$ 2605(a)(c)(1)(o)$. In determining whether or not a chemical substance presents an "unreasonable risk," EPA must consider "the reasonably ascertainable economic consequences of the rule, after consideration of the effect on the national economy, small business, technological innovation, the environment and public health. FIFRA $\S 3(c)(5)(D), 7$ USC $\S 136 a(c)(5)(D)$ (1988). Under FIFRA, EPA must register a pesticide if it determines that "it will not generally cause unreasonable adverse effects on the environment." Unreasonable adverse effects are defined in $\S 2$ (bb) to require consideration of "the economic, social, and environmental costs and benefits of the use of any pesticide." Id at $\$ 136(\mathrm{bb})$.

391. 15 USC $\$ 2605$ (a).

392. Ronald Outen, Environmental Pollution Laws and the Architecture of Tobacco Road, in Multimedia Approaches to Pollution Control: Symposium Proceedings 139, 142 (Natl Res Council, 1987). If one were to design a law to achieve efficient, cross-media regulation in an integrated fashion,

[i]t would need to be broad in scope, capable of reaching any environmental medium. To achieve the greatest efficiency in regulatory decisions, it would need to be able to reach polluting substances at any point that they exist in the marketing chain, as well as ultimate disposal. You would want it to be risk-based, not technology driven, so that optimization decisions could be made. You would want to be able, for example, to perform comparative risk assessments in order to identify the most socially optimum distribution of pollution, where environmental release is warranted by the benefit/cost balancing. And you would want to be driven toward the least cost approach that would achieve whatever result is determined to represent the most acceptable social risk.

Id. The only problem with this fantasy statute is that the law "is already on the books" in the form of TSCA, and it has not worked very well in part because "[i]t is too easy to get tied up in analytical knots." Id.

393. See, for example, Sidney A. Shapiro \& Thomas O. McGarity, Reorienting OSHA: Regulaton Alternatives and Legislative Reform, 6 Yale J Reg 1, 3, 6.7 (1989) (no agency has been able to regulate more than three controversial chemicals in any given year; limited agency resources constrain agency regulatory capabilitics); Sunstein, $57 \mathrm{U}$ Chi L Rev at 415 (cited in note 193) (elaborate and costly procedural requirements build "enormous delays and perverse incentives" into environmental regulation schemes). 
A more satisfactory explanation for EPA's failure to implement environmental statutes aggressively is that environmental regulation inevitably requires choices that create winners and losers. Pollution control regulations can impose significant compliance costs on politically powerful business interests; presumably these regulations benefit environmental interests that have acquired considerable political influence as well. Because its regulatory decisions inevitably will benefit some interests and harm others, EPA is reluctant to act decisively on its own initiative. ${ }^{394}$ Thus, most significant regulatory actions undertaken by EPA have occurred only after EPA has been subjected to strong outside pressure. ${ }^{395}$

It is not difficult to understand why delay would be the response preferred by a regulatory agency faced with a decision that inevitably will upset some significant interests. Agencies often can justify delays on the ground that more study needs to be undertaken. Because of the enormous uncertainties that surround assessments of the effects of regulatory actions, there are always issues that are good candidates for further study. While environmentalists are likely to be more upset than industries about delays, they also may be tolerant of those delays occasioned by further study if they believe such study ultimately will produce results more favorable to their positions.

One of the reasons Congress has delegated such significant responsibility to EPA is Congress's own reluctance to determine precisely who the winners and losers should be in allocating the burden of environmental regulation. It is not surprising that the same political conflicts that make Congress unwilling to legislate with more precision also would hamper an administrative agency's implementation of the regulatory statutes. ${ }^{396}$

Thus, although presidential oversight, in theory, can serve as a politically responsive check on single-mission agencies, the Reagan Administration's agency capture diagnosis was misguided in its application to EPA. Indications that the medicine OMB review has provided to EPA is entirely different in character from what would be prescribed to redress agency capture suggest the need for an alternative explanation of regulatory review.

\section{B. Public Choice and a Theory of Regulatory Review}

Despite differences in the structure of the various regulatory review programs, a consistent pattern of presidential intervention to moderate the cost of implementing environmental legislation has emerged. The tug-of-war between the president and Congress over control of environmental policy can be explained in part by the fact that the presidency and Congress have been controlled by opposition parties throughout most of the history of EPA.

394. Dwyer, 17 Ecol L $Q$ at 278 (cited in note 384).

395. This pressure can be in the form of citizen suits against EPA for failure to perform nondiscretionary duties. leading to court-ordered deadlines for EPA action. See EESI, Statutory Deadlines (cited in note 379 ).

396. See Louis L. Jaffe, The Illusion of the Ideal Administration, 86 Harv L Rev 1183, 1190 (1973). 
However, it is possible to outline a more general theory of regulatory review to explain the historical patterns that have emerged.

Because environmental protection has been consistently popular throughout the last two decades, the enactment of environmental legislation can produce immediate political benefits for Congress and the president. Politicians can proudly point to new laws as demonstrating that they have acted to protect the environment, even though the impact of the laws on environmental quality may depend largely on the issuance and enforcement of implementing regulations by administrative agencies.

Yet the process for developing regulations to implement the environmental statutes does not promise great political rewards for several reasons. First, the regulatory process is far less visible and understandable to the environmentally concerned public than is the legislative process, despite the participatory model of regulatory decisionmaking embodied in the Administrative Procedure Act. ${ }^{397}$ Second, industries subject to regulatory action have greater incentives to participate in the regulatory process than does the environmentally concerned public. While national environmental groups will participate in rulemaking proceedings of national importance, industries subject to environmental regulation will have a great incentive to participate in any rulemaking that may impose significant compliance costs on them.

Third, the benefits of environmental regulation, though often substantial, typically accrue over long periods of time in ways that are not nearly as visible as the impacts of compliance costs. ${ }^{398}$ Thus, by postponing compliance costs, a delay in implementing an environmental regulation may generate benefits that are more immediate and tangible to consumers and the regulated industry than are the long-term costs to the environment.

Fourth, because environmental regulation inevitably creates winners and losers, environmental legislation creates new opportunities for gains by those who can influence the course of the implementation process. ${ }^{399}$ The regulated community has a tremendous incentive to seek to delay or weaken implementing regulations. The president, in the short run, can reap political rewards from the regulated community by exercising Executive Office oversight that moderates the impact of environmental regulations on industry. If this oversight is largely hidden from public view, the political costs are likely to be minimal and are greatly offset by the benefits accruing to the president from the grateful regulated industry. ${ }^{400}$

397. See id at 1185; see also David Schoenbrod, Goals Statutes or Rules Statutes: The Case of the Clean Air Act, 30 UCLA L Rev 740, 753-54 (1983) (the former arguing that broad delegations of power promote responsibility only if the subject of the delegation is highly visible; the latter illustrating the lack of visibility of the Clean Air Act implementation process).

398. For example, by reducing virtually invisible levels of asbestiform fibers, EPA's asbestos ban will prevent cases of lung cancer and mesathelioma that have a latency period of twenty years or more. 54 Fed Reg 29460, 29469 (July 12. 1989).

399. Sec generally Rodgers, $4 \mathrm{~J}$ land Use \& Envir Law 377 (cited in note 222).

400. Ironically, OMB director James C. Miller, III, has sought to defend Executive Office review as a device to prevent agency capture because it raises the costs of lobbying and because OMB 
Having garnered the political benefits from enacting legislation, legislators can reap additional benefits by attacking lax implementation of the laws by administrative agencies and by amending the laws to force more aggressive agency action. Because the president is responsible for the activities of executive agencies, legislators also can score points against a president from an opposing party by exposing efforts to weaken the implementation of environmental statutes. ${ }^{401}$ These factors help explain why the exercise of executive oversight has been, and is likely to continue to be, highly controversial.

\section{Legal Constraints on Executive Office Oversight}

Questions concerning the legal bounds of Executive Office oversight of agency rulemaking have sparked considerable scholarly debate. Critics of $\mathrm{OMB}$ review argue that it has illegally displaced decisionmaking authority vested by Congress in EPA and that it has produced decisions that are not based on standards required by statute. ${ }^{402}$ While some supporters of the regulatory review program have acknowledged the danger of abuse, they emphasize that the executive orders are carefully structured to preserve their facial legality. ${ }^{403}$

Executive Orders 12291 and 12498 attempt to avoid serious legal and constitutional difficulties by tempering the expansive scope of the review authority granted to OMB. Both orders provide that OMB is authorized to take action only "to the extent permitted by law" 404 and exempt regulations from OMB review if such review would conflict with statutory or judicial deadlines. ${ }^{405}$ Executive Order 12291 also specifies that nothing in the order "shall be construed as displacing the agencies' responsibilities delegated by law." 406

These provisions repeatedly are cited whenever the legality of OMB's actions is challenged. The Department of Justice has acknowledged the importance of interpreting the executive orders in a manner that avoids a

reviewers supposedly must deal with all conflicting interests. Miller, Shughart \& Tollison, 43 Public Choice at 85 (cited in note 374 ). Yet these very factors can have precisely the opposite effect. The fact that $\mathrm{OMB}$ review raises lobbying costs works to the substantial benefit of the regulated community that has far greater lobbying resources than public interest groups. Moreover, because ORB staff "are naturally more responsive to an administration's friends than to its enemies," in an administration that uses OMB to champion the interests of the regulated community, regulatory review is likely to reinforce agency capture. Bruff, 57 Geo Wash L Rev at 554 (cited in note 298).

401. Legislators also may benefit from OMB intervention on behalf of their business constituents. See Morrison, 99 Harv L Rev at 1071 (cited in note 173).

402. See for example, Brief of Representatives John D. Dingell, et al, as Amici Curiae, Public Citizen v Rowland, No 84-1252 (DC Cir Jan 23, 1985) (OMB review has displaced agency decisionmaking authority, prevented meaningful public participation, and caused the application of statutorily impermissible criteria); Morton Rosenberg, Beyond the Limits of Executive Control of Agency Rulemaking Linder Executive Order 12291, 80 Mich L Rev 193 (1981).

403. See, for example, Strauss \& Sunstein, 38 Admin L Rev at 187-91 (cited in note 298).

404. Exec Order 12291, §§2,3(a), 6(a), 7(e), 3 CFR 128-32; Exec Order 12498, §4, 3 CFR 325 (1986).

405. Exec Order 12291, § 8(a)(2), 3 CFR 133; Exec Order 12498, § 3(c), 3 CFR 324-25.

406. Exec Order 12291, \&3(f)(3), 3 CFR 130. 
collision with constitutional principles of separation of powers. In its opinion supporting the legality of Executive Order 12291, the Department emphasized that "the president's exercise of supervisory powers must conform to legislation enacted by Congress." 407 Therefore, "[i]n issuing directives to govern the Executive Branch, the president may not, as a general proposition, require or permit agencies to transgress boundaries set by Congress." 408 To prevent the president from usurping authority delegated to EPA, the executive orders are founded on the theory that OMB's role is "advisory and consultative" and does not include authority to reject an agency's ultimate judgment on matters delegated to it by law. ${ }^{409}$

OMB officials have recognized the importance of this limitation for preserving at least the appearance of legality for the regulatory review program. ${ }^{410}$ Fear that $\mathrm{OMB}$ would be subject to legal action or an adverse judgment in court occasionally has resulted in rapid clearance for regulatory packages. ${ }^{411}$

Dictum in Judge Wald's majority opinion in Sierra Clubv. Costle 412 provides the clearest judicial endorsement of the legality and propriety of regulatory review. Judge Wald recognized not only the constitutional authority of the president to supervise executive policymaking, but also the desirability of such presidential oversight. ${ }^{413}$

407. Memorandum from U.S. Department of Justice, Office of Legal Counsel, Proposed Executive Order Entitled "Federal Regulation" (Feb 13, 1981), reprinted in OMB Hearings at 486 (cited in note 121 ).

408. Id.

409. Id at 492.

410. For example, when he was serving as administrator of OIRA, James C. Miller, III, who later became director of $\mathrm{OMB}$, stated:

The limited application of [Exec Order 12291] is a crucial point, one that ensures [its] legality and the legality of actions pursuant to it. If a statute expressly or by necessary implication prohibits the consideration of benefits or costs or alternatives by an agency during its rulemaking, then those provisions of Executive Order 12291 imposing them would not apply. If a statute or court order establishes a date for rule-making action, then Executive Order 12291 cannot delay that action. In other words, if Congress or the courts have spoken on the matter, then the Executive Order process will conform to that expression, not contradict it.

Id at 46.

411. See note 197 and accompanying text.

412. 657 F2d 298 (DC Cir 1981), rev'd on other grounds, Ruckelshaus y Sierra Club, 463 US 680 (1983)

413. Wald wrote that:

[t]he authority of the president to control and supervise executive policymaking is derived from the Constitution; the desirability of such control is demonstrable from the practical realities of administrative rulemaking. . . Our form of government simply could not function effectively or rationally if key executive policymakers were isolated from each other and from the Chief Executive. Single mission agencies do not always have the answers to complex regulatory problems. An overworked administrator exposed on a 24-hour basis to a dedicated but zealous staff needs to know the arguments and ideas of policymakers in other agencies as well as in the White House.

Costle, 657 F2d at 406 (ruling that EPA's failure to mention a meeting between it and the president in a rulemaking docket did not invalidate the subject regulations because they were not based on information arising from the meeting). 
Judge Wald's opinion, however, also recognizes limits on the president's supervisory authority. Her discussion of the relationship between the president and the EPA administrator appears to assume that the administrator retains ultimate responsibility for the regulatory decision. Judge Wald notes that the administrator "needs to know the arguments" of White House staff, not that he must ultimately adopt them. ${ }^{414}$ She recognizes that the president may be successful in "prodding" the administrator into adopting a different regulation, but she does not imply that the president has the authority to dictate the result. 415

As a practical matter, the president's ability to fire the EPA administrator gives him enormous power to influence EPA decisions. Moreover, Judge Wald's opinion suggests that if the president is successful in persuading the EPA administrator to change his decision, the regulations would still be upheld unless they lacked adequate support in the rulemaking record. ${ }^{416}$ But this does not necessarily mean that the president has the authority to make the decision for EPA. The Supreme Court has explicitly rejected the notion that Congress could not limit or condition the president's constitutional authority to supervise the actions of executive branch officials. ${ }^{417}$

Historical understandings and the text of article II of the Constitution support the notion that "the President is not authorized either to make particular decisions statutorily vested in at least some subordinate officials, or to direct those officials to make particular decisions-except insofar as the prospect of removal operates as such a direction." 418 According to this view, if the EPA administrator refuses to make a particular decision that the president wishes him to make, the president's only recourse is to discharge him and appoint a new administrator who shares the president's views.

As a practical matter, few EPA administrators would defy the president at the risk of losing their job. However, political constraints on the president's removal power, as illustrated by the history of both the Watergate controversy and regulatory review of EPA decisionmaking, ${ }^{419}$ dictate that it will be used sparingly. A clearer limitation on the president's supervisory authority is that it may not be used to produce decisions that are based on statutorily impermissible factors. The executive orders' statements that agencies are to comply with the orders' directives only "to the extent permitted by law"

414. Id.

415. Id at 408

416. "After all, any rule issued here with or without White House assistance must have the requisite factual support in the rulemaking record, and under this particular statute the Administrator may not base the rule in whole or in part on any 'information or data' which is not in the record, no matter what the source." Id at 407-08. But compare Public Citizen Health Research Group $v$ Tyson, 796 F2d 1479, 1507 (DC Cir 1986) (declining to reach issue of OMB's authority because agency action taken at OMB's behest was without support in the record, but noting that OMB's role in the decision "presents difficult constitutional questions concerning the executive's proper rule [sic] in administrative proceedings and the appropriate scope of delegated power from Congress to certain executive agencies").

417. Morrison v. Olson, 487 US 654, 695-96 (1988).

418. Strauss \& Sunstein, 38 Admin L Rev at 201 (cited in note 298).

419. See text accompanying notes $42,56,61,111-13$. 
reflect this limitation. ${ }^{420}$ The president lacks the constitutional authority to countermand valid statutory directives, for such action would infringe upon legislative powers vested in Congress by the Constitution. As the Supreme Court has held, the president's executive powers under article II of the Constitution do not permit him to authorize executive officers to act in a manner that is inconsistent with policies established by Congress. ${ }^{421}$

This principle has been recognized by courts reviewing the products of OMB review. Environmental Defense Fund v. Thomas held that "OMB has no authority to use its regulatory review under Executive Order 12291 to delay promulgation of EPA regulations . . . beyond the date of a statutory deadline." 422 The court reasoned that although a "certain degree of deference must be given to the authority of the president to control and supervise executive policymaking," action to block promulgation of regulations required by statute "is incompatible with the will of Congress and cannot be sustained as a valid exercise of the president's Article II powers." 423

This decision illustrates the potentially serious threat that regulatory review poses to separation of powers principles. Aside from OMB's implementation of the Paperwork Reduction Act ${ }^{424}$ the regulatory review program is exclusively the product of the executive orders rather than of legislation. An effort by the president to expand his own powers to dictate the substance of environmental policy poses a particular threat to separation of powers principles. As the Supreme Court recognized in INS v. Chadha, "[t]he hydraulic pressure inherent within each of the separate Branches to exceed the outer limits of its power, even to accomplish desirable objectives, must be resisted." 425

While scholars have recognized the danger that regulatory review would exceed the bounds of executive authority, their enthusiasm for its theoretical advantages in improving regulatory coordination has made them reluctant to endorse substantial changes in the review process. ${ }^{426}$ In contrast, public interest groups, obsessed by OMB's abuses of regulatory review, have advocated eliminating it entirely without considering whether regulatory review could be transformed into a positive tool for improving regulatory policy. ${ }^{427}$ Thus, much of the commentary on regulatory review has focused on either insufficiently pragmatic theoretical defenses of it or insufficiently theoretical attacks. The section that follows explores the possibility that

420. Exec Order 12291, §§ 2, 3(a), 6(a), 7(e), 3 CFR 128-32; Exec Order 12498, § 4, 3 CFR 325.

421. Youngstown Sheet \& Tube Co. v Sauyer, 343 US 579, 587-88 (1952).

422. 627 F Supp at 571

423. Id at 570 .

424. See text accompanying note 116

425. INS v Chadha, 462 US 919, 95I (1983).

426. See, for example, Reauthorization Hearings at 58 (cited in note 218 ) (testimony of Cass $\mathbf{R}$. Sunstein: "If $\mathrm{OMB}$ is introducing political considerations, understood as its own ideology, independent of what Congress wants, then that is illegality and something ought to be done about it ... But all the formal papers, even OMB's formal papers, say that is unlawful and not permitted.").

427. See id at 52 (statement of David Vladeck, spokesperson for Public Citizen). 
regulatory review could be restructured into a vehicle for improving regulatory policy by addressing flaws in its theory and abuses in its practice.

VI

\section{Toward a Reformulated Model for Executive Oversight}

Improved coordination and increased accountability in decisionmaking are highly desirable, but the history of Executive Office oversight of EPA demonstrates that regulatory review often has not been used to promote such goals. Rather, the Executive Office frequently has succumbed to the temptation to use regulatory review to pursue more overtly political ends, such as providing "regulatory relief" to industry, that may be at odds with statutory directives. ${ }^{428}$ Consequently, regulatory review has exacerbated the fundamental tension between political control and the impartial administration of law. "In essence, OMB review institutionalizes the primacy of politics. As a result, it inevitably clashes with a process that responds to a very cifferent ideal-an ideal that subordinates political control to formalized proceedings, to decision making that is closely tied to documented evidence and to judicial review." 429 While the political process itself can serve as an imporiant deterrent to abuses of executive oversight authority, that deterrence depends on public disclosure that is not guaranteed under regulatory review regimes.

The failure of the Reagan Administration's regulatory review program to achieve its goals of regulatory relief can be traced to the administration's decision not to seek basic changes in the environmental statutes and to its obsession with regulatory relief rather than genuine regulatory reform. ${ }^{430}$ In both respects the administration sought to short-circuit the constitutional structure of federal policymaking to make changes that were consistent with its own vision of desirable environmental policy, but were inconsistent with the elaborate structure of environmental law. By employing regulatory review to pursue such change, the administration prescribed strong medicine based on an incorrect diagnosis of agency failure. This error transformed a potentially useful tool for improving regulatory policy into an engine for its further balkanization.

The distrust generated by the politicization of the review process has stimulated a congressional backlash. As a result, Executive Office intervention has largely been unsuccessful in providing "relief" to the

428. While it is clear that OMB frequently has tried to influence EPA decisions in a manner at odds with statutory standards, this is not a feature of regulatory review that is unique to the Reagan and Bush Administrations. Accounts of the RARG process in the Carter Administration indicate that the Executive Office sought to weaken standards under the Clean Air Act by having EPA consider economic factors not permitted under the statute. This is perhaps inevitable so long as regulatory review focuses nearly exclusively on economic considerations.

429. Cooper \& Wright, $50 \mathrm{~J}$ Politics at 882 (cited in note 212 ).

430. See, for example, Jeffrey A. Eisenach, $A$ White House Strategy for Deregulation, in Charles L. Heatherly \& Burton V. Pines, eds, Mandate for Leadership: Policy Strategies for the 1990s, 87, 89 (Heritage Foundation, 1989); Eads \& Fix, Relief or Reform? at 255-58 (cited in note 26). 
regulated community. Rather, it has inspired Congress to intensify its own oversight activities and to produce increasingly explicit legislation narrowing EPA's discretion. Caught in a tug-of-war between the president and Congress over control of regulatory policy, EPA has lost much of its flexibility to develop and implement effective environmental policies.

Abuses of the regulatory review process make reform of the process more urgent, but they do not warrant a complete abandonment of regulatory review. A new model of regulatory review could transform the process into a positive tool for ensuring that EPA performs its statutory responsibilities more efficiently, expeditiously, and equitably. ${ }^{431}$ Executive Orders 12291 and 12498 should be replaced with a restructured regulatory review process that emphasizes the following policies.

First, any program of regulatory review should be founded on the principle that fidelity to statutory requirements, rather than to the preferences of the president or the regulated community, should be the touchstone of regulatory decisionmaking by EPA officials. A program that pays only lip service to this principle by sanctioning regulatory review "to the extent permitted by law" simply invites abuse, particularly when it places responsibility for conducting review largely in the hands of economists hostile to statutory values. If the president deems the regulatory policies established by the environmental laws unwise, he should propose modifying legislation. If Congress resists the president's legislative initiatives, the president can seek to enlist public support. But he cannot indirectly amend or repeal the environmental laws by dictating that regulatory action be taken in a manner inconsistent with their requirements.

Second, the regulatory review process should be used as a management tool to ensure that EPA has sufficient resources and to monitor EPA's timeliness in performing its regulatory duties. ${ }^{432}$ This could help to redress the chronic delays that have plagued the regulatory process and might encourage EPA to pursue innovations that reverse the incentives for delay and that shift the burdens of delay away from the beneficiaries of regulation.

While it is often argued that some of the environmental statutes contain hopelessly unrealistic goals, ${ }^{433}$ EPA has had considerable difficulty

431. Robert V. Percival, Back to Basics: An Environmental Policy for the 1990s, Envir Forum 21,26 (March/April 1988); Robert V. Percival, Restoring Regulatory Policy to Serve the Public Interest, in Marcus Raskin \& Chester Hartman, eds, IVinning America: Ideas and Leadership for the 1990s, 48, 48-52 (South End Press, 1988).

432. For example, the GAO reported in July 1988 that of the 06 deadlines in the 1984 Hazardous and Solid Waste Amendments that had expired, EPA had met three of the four statutory deadlines with hammer provisions, but only 24 (or $39 \%$ ) of the 62 deadlines without hammer provisions. New Approach Needed to Manage the Resource Conservation and Recovery Act 74-75 (Gen Acct Office, 1988). When sued for failure to meet the deadlines, EPA maintained that the principal reason was a lack of resources. It proposed a schedule for completing the various rulemakings requiring by extending deadlines to November 1992. Under EPA's proposed schedule, it will not complete the last of these actions until December 2004. See Environmental Defense Fund, No 89-598 (declaration of Sylvia K. Lowrance).

433. Frequently cited examples are the Clean Water Act's zero discharge goal for water pollutants, 33 USC $\S 1251$ (a)(1); the Delaney Clauses of the Federal Food, Drug and Cosmetic Act, 
implementing even far more reasonable regulatory statutes. ${ }^{434}$ One source of this difficulty has been funding that is chronically inadequate to carry out the agency's full range of responsibilities. EPA's implementation of early environmental statutes was hampered by OMB's ability to set the agency's budget without regard for what it would take to implement these laws. ${ }^{435}$ During the early years of the Reagan Administration, OMB actually cut EPA's budget dramatically in an attempt to impede its ability to implement these laws. ${ }^{436}$ A "kinder, gentler" reviewing body committed to assisting EPA in performing its statutory responsibilities could make an important contribution by integrating into the budget process a more realistic appraisal of the demands placed upon EPA.

Because of OMB's bias against regulation, it rarely has been concerned about delays in the regulatory process; rather, it has used regulatory review to increase delay. In fact, OMB has taken agencies to task only for delays involving initiatives to weaken or repeal regulations. ${ }^{437}$ A more even-handed concern about regulatory delay would be a step toward improving the efficiency of EPA's notoriously lengthy regulatory processes.

Third, the regulatory review process should be restructured to increase accountability for policy decisions. While ostensibly designed to achieve this goal, the existing regulatory review process actually has achieved the opposite effect by blurring the lines of responsibility. When the Executive Office succeeds in blocking or weakening EPA regulations, EPA officials are forced to engage in the pious fiction that they have been "convinced" by OMB's arguments because of the recognition that $\mathrm{OMB}$ does not have the legal authority to displace EPA decisionmaking. While this preserves the fiction that EPA retains ultimate decisionmaking authority, in other circumstances it allows EPA to escape responsibility for unpopular decisions actually made by the agency by suggesting that OMB is the villain.

21 USC $\S \S 348(\mathrm{c})(3)(\mathrm{A}), 376$ (b)(5)(B) (1988), that bar the use of food and color additives shown to induce cancer in man or animals; and section 112 of the Clean Air Act, 42 USC $\S 7412(\mathrm{~b})(1)(\mathrm{B})$, which requires EPA to regulate hazardous air pollutants to provide an "ample margin of safety." "By enacting this type of statute, legislators reap the political benefits of voting for 'health and the environment' and against 'trading lives for dollars,' and successfully sidestep the difficult policy choices that must be made in regulating public health and the environment." Dwyer, 17 Ecol L Q at 233 (cited in note 384 ).

434. See notes $349-53$ and accompanying text.

435. See, for example, EPA's Budget Request for Fiscal Year 1975, Hearings before the Subcommittee on Environmental Pollution of the Senate Public Works Committee, 93d Cong, 2d Sess 210-13 (1974) (testimony of Russell Train).

436. Eads \& Fix, Relief or Reform? at 148-55 (cited in note 26).

437. See, for example, Sandra Sugawara, OSHA Is Taken to Task for Failure to Keep Pace With the Administration's Schedule for Regulatory Relief Publication, Washington Post Al (Sept 27, 1982) (reporting on a letter from OIRA Administrator Christopher DeMuth to Labor Department Solicitor T. Timothy Ryan, Jr., complaining about "a troublesome regulatory lag" due to slippages in target dates for completing regulatory relief initiatives and recommending steps to accelerate and expedite action). But compare Memorandum from Wendy L. Gramm to the Heads of Certain Departments and Agencies, Completion of the 1986 Regulatory Program (May 28, 1986) (copy on file with author) (expressing concern because agencies missed $38 \%$ of their own deadlines for making significant regulatory action by two months or more). 
There are two major alternatives available for preventing OMB from displacing EPA's exercise of decisionmaking authority-restructuring EPA as an independent agency, or restructuring the regulatory review process to prevent a reviewing authority from exercising de facto veto power over agency regulations. While the former option is clearly available in light of the Supreme Court's recognition that Congress has the constitutional authority to create independent agencies, ${ }^{\mathbf{4 3 8}}$ it is not clear that it is a desirable vehicle for improving agency accountability. In some circumstances, efforts to weaken the president's ability to fire agency heads will reduce accountability. For example, had EPA been an independent agency during the scandal that ultimately led to the resignation of EPA Administrator Burford, the public surely would have been outraged had the president been unable to remove her. Moreover, it is anything but clear that agencies that are independent in principle are independent in practice. Indeed, experience has shown that the independent agencies often have been the most subject to capture by the regulated community. ${ }^{439}$

A more appropriate means for increasing accountability for decisionmaking is to restructure the regulatory review process so that EPA retains the ultimate responsibility for regulatory decisions in both theory and practice. This goal can be pursued by placing strict time limits on regulatory review that prevent a reviewing entity from exercising de facto veto power by blocking regulations indefinitely.

Moreover, disclosure policies should permit the public to monitor the progress of all regulatory initiatives. The substance of regulatory review should be placed on the public record so that reviewing courts and the public can assess the rationality and legality of ultimate agency action. Decisions that appear to be the product of pressure from the White House, rather than the agency's best factual and policy judgments, should not be afforded judicial deference, because the rationale for such deference no longer applies. Public monitoring of the regulatory process would require disclosure of the status of any pending regulatory proposal, even though such disclosure is not required under the current interpretation of the Freedom of Information Act. ${ }^{440}$ While this could facilitate lobbying by regulated industries, it also would help prevent regulatory proposals from languishing in a black hole hidden from public view.

Given OMB's history, it may be necessary to transfer regulatory review to a part of the Executive Office that does not have such a narrowly defined mission. The Council on Environmental Quality, for example, could be revitalized to perform a broader function in coordinating environmental

438. See Morrision v Olson, 487 US 654 (1988).

439. See Sunstein, 57 U Chi L. Rev at 426-28 (cited in note 193).

440. Wolfe "Dept of Health and Human Services, 839 F2d 768 (DC Cir 1988) (en banc). 
initiatives and in ensuring that EPA expeditiously and efficiently carries out its statutory responsibilities. At the time EPA was created, the Nixon Administration rejected the notion that CEQ should resolve disputes between EPA and other federal agencies in favor of OMB performing this function. ${ }^{441}$ By placing control over regulatory review in the hands of an agency whose primary mission has been to reduce costs to industry, the QOL program and its successors have used regulatory review as a mechanism for weakening environmental regulation. A more enlightened approach to regulatory review would place control over this process in the hands of an agency whose mission is to ensure that federal regulatory policies are implemented in a more balanced fashion. While some form of regulatory review has been employed by every administration since the creation of EPA, it has become a source of considerable friction between the executive and legislative branches largely because of the lack of balance with which it has been conducted. To transform regulatory review from a check without balance into a positive force for improving regulatory policy, the review process should be restructured to emphasize the president's constitutional responsibility to "take care that the laws be faithfully executed" rather than an administration's hostility toward regulatory statutes.

441. See Marcus, $54 \mathrm{~L}$ \& Contemp Probs at 21 (cited in note 22). 